\title{
Sociedades mercantiles: libertad de establecimiento y conflicto de leyes en la unión europea
}

\author{
Alfonso-Luis Calvo Caravaca \\ Catedrático de Derecho internacional privado \\ Universidad Carlos III de Madrid \\ Vocal Permanente en la Sección Civil de la Comisión General de Codificación \\ $\mathrm{y}$ \\ Javier Carrascosa González \\ Profesor titular de Derecho internacional privado \\ Universidad de Murcia
}

Recibido: 02.10 .06

Aceptado: 10.10 .06

Resumen: Las últimas sentencias del Tribunal de Justicia de la UE han confirmado que los particulares pueden constituir sociedades en el Estado miembro que deseen. Los demás Estados miembros están obligados a reconocer la válida constitución de dichas sociedades con independencia del Estado miembro de la UE en el que desarrollen la mayor parte de sus actividades. Las normas de conflicto de Leyes de los Estados miembros no pueden alterar esta regla. La UE apunta a la elaboración de un Reglamento que indica que la Ley que rige las sociedades es la Ley del Estado con arreglo al cual se ha constituido la sociedad.

Palabras clave: Sociedades. Mercado único europeo. Libertad de establecimiento. Derecho internacional privado. Conflictos de Leyes en Europa

Abstract: The last judgments of the European court of Justice have cleared that individuals have the right to establish a company under the Law of the Member State they freely choose. The other Member States must recognize the company as validly created regardless the Member State where the company runs its business. The Conflict-Of-Laws Rules of the Member States can not modify this rule. The UE aims to elaborate a Regulation concerning the Law applicable to companies: the law governing companies should be the Law of the State where the company has been incorporated.

Key words: Companies. Single european market. Freedom of establishment. Private International Law. Conflict-Of-Laws in Europe.

Sumario: I. El mercado comunitario y la libertad de establecimiento. 1. Introducción. 2. La libertad de establecimiento: concepto. 3. Sociedades titulares del derecho a la libertad de establecimiento en la UE.--II. La regulación jurídica de las sociedades en la UE y en los Estados miembros. - III. Determinación de la Ley aplicable a las sociedades de capital en los Estados miembros.-IV. Las normas de conflicto societarias como obstáculo a la libertad de establecimiento de las sociedades en la UE. 1. El obstáculo: las normas de conflicto de los Estados miembros en materia societaria. 2. La labor del TJCE y la trilogía societaria Centros - Überseering - 
Inspire Art. 3. Primera solución: la técnica de la «regla de reconocimiento comunitario de situaciones jurídicas» (Anerkennungsprinzip). A) Formulación de la regla. B) Base teórica y técnica de la regla. C) Alcance de la regla. D) El fantasma (inexistente) del fraude y del abuso de Derecho. E) Formulación legal y judicial de la regla. 4. Segunda solución: la técnica del conflicto de Leyes y la unificación futura de las normas de conflicto de los Estados miembros en materia societaria. A) Comunitarización de las normas de conflicto societarias. B) Hacia una victoria de la Incorporation Theory.-V. Perspectiva comunitaria y normas de conflicto españolas en materia societaria en la actualidad. 1. Nacionalidad de las sociedades. 2. Criterio utilizado para determinar la Ley reguladora de las sociedades corporativas.-VI. Reflexión final.

\section{El mercado comunitario y la libertad de establecimiento}

\section{Introducción}

1. El mercado único europeo es un espacio de libertad al que concurren productores y oferentes de bienes y servicios, por un lado, y adquirentes y consumidores, por otro ${ }^{1}$. Son las sociedades de capital, y más especialmente, las sociedades mercantiles, los auténticos sujetos protagonistas del comercio internacional intracomunitario. Las sociedades de capital son los sujetos que invierten, producen, crean puestos de trabajo, introducen innovaciones tecnológicas e ideas, adquieren bienes y servicios. Son los sujetos que mueven la riqueza en el mercado único comunitario. Desde el punto de vista jurídico, son las sociedades de capital las protagonistas principales de la contratación internacional, de la adquisición y explotación de los derechos reales y propiedades especiales, de los procedimientos concursales, de la competencia empresarial. Por ello, no puede sorprender que las tres sentencias más importantes dictadas en materia societaria por el TJCE en los últimos años hayan suscitado un debate de enorme riqueza teórica y de incalculable proyección práctica: STJCE 9 marzo 1999, Centros Ltd vs. Erhvervsog Selskabsstyrelsen, STJCE 5 noviembre 2002, Überseering BV vs. Nordic Construction Company Baumanagement GmbH (NCC), STJCE 30 septiembre 2003, Kamer van Koophandel en Frabrieken voor Amsterdam vs. Inspire Art. Tres «sentencias capitales» en la evolución del Derecho comunitario

${ }^{1}$ A. L. Calvo Caravaca / J. Carrascosa González, Mercado único y libre competencia en la Unión Europea, Editorial Colex, Madrid, 2003, pp. 25-32, en lo relativo a los caracteres y funcionamiento del mercado único, y pp. 87-200, por lo que concierne a la incidencia de la libertad de establecimiento en la conformación del mercado único. Igualmen-

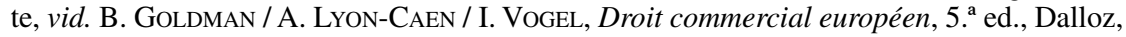
París, 1994, pp. 98-104. 
y de los «conflictos de Leyes» en Europa, como escribe B. AudiT ${ }^{2}$. Y esta línea de jurisprudencia está a un paso de ser confirmada, otra vez más, en el caso Cadbury, pues las Conclusiones del Abogado General Sr. Philippe Léger presentadas el 2 mayo 2006, as. C/196/04, Cadbury Schweppes plc, Cadbury Schweppes Overseas Ltd vs. Commissioners of Inland Revenue, no dejan lugar a dudas.

2. El mercado comunitario es un espacio en el que se encuentran más de 400 millones de consumidores y que cubre, a fecha de 13 septiembre de 2006, el territorio de 25 países. Y hay dos países más, Bulgaria y Rumanía, con muy altas probabilidades de entrar a formar parte del «club comunitario» en primavera de 2007. En el mercado comunitario, innumerables empresas compiten por un puesto privilegiado. La lucha es dura. La competencia debe sujetarse a unas reglas. En caso contrario, peligra la existencia misma y el buen funcionamiento del mercado. El mismo Derecho comunitario establece unas normas básicas de comportamiento en dicho mercado. Tales normas desarrollan los postulados de la economía libre de mercado. Y en una economía libre de mercado, los sujetos que ofrecen bienes y servicios, los que deciden qué se produce, cómo se produce y para quién se produce, son las empresas, y en especial las grandes empresas de dimensión internacional, y los profesionales liberales. No los Estados. Pues, si las empresas son las encargadas de hacer avanzar la locomotora económica europea, es imprescindible que el Derecho comunitario garantice una verdadera competencia en todos los sectores y la transparencia del mercado. La «liberalización del mercado» es la mejor garantía para una afluencia suficiente de competidores en el espacio comunitario. Dicha liberalización se alcanza a través del desarrollo normativo de tres grandes ejes: a) las libertades comunitarias que conforman el mercado interior; b) la defensa de la libre competencia; c) las políticas comunes en determinados sectores, en especial, la política comercial común.

\section{La libertad de establecimiento: concepto}

3. Entre las libertades comunitarias, ocupa un puesto de privilegio en la actividad empresarial la llamada «libertad de establecimiento» ${ }^{3}$. La libertad

\footnotetext{
${ }^{2}$ B. Audit, Droit international privé, Economica, París, 4. ${ }^{\text {a }}$ ed., 2006, p. 880.

${ }^{3}$ En torno a la la importancia de las libertades comunitarias como instrumento para crear y mantener un auténtico «mercado único» en la UE, vid. A.L. CAlvo Caravaca / J. CARRascosa GonzÁlez, Mercado único y libre competencia en la Unión Europea, Editorial Colex, Madrid, 2003, pp. 29-32 y en particular, sobre la libertad de establecimiento, pp. 87-200; C. BARnard, The Substantive Law of the EU. The Four Freedoms, Oxford, 2004, esp. pp. 12-33; M. Boger, Die Anwendbarkeit der Cassis-Formel auf Ungleichbehandlungen im Rahmen der Grundfreiheiten: eine Untersuchung auf Grundlage der Rechtsprechung
} 
de establecimiento, hoy regulada en los arts. 43-48 TCE, puede definirse como el «derecho subjetivo reconocido a los nacionales en los Estados miembros que consiste en el acceso a actividades económicas independientes en el territorio de otros Estados miembros, mediante la fijación de una

des EuGH unter besonderer Berücksichtigung des Begriffs der mittelbaren Diskriminierung, Berlín, 2004; A. BRIGOLA, Das System der EG-Grundfreiheiten: vom Diskriminierungsverbots zum spezifischen Beschränkungsverbot, Munich, 2004; L. CRONES, Grundrechtlicher Schutz von juristischen Personen im europäischen Gemeinschaftsrecht: eine rechtsvergleichende Untersuchung zum persönlichen Anwendungsbereich der Grundfreiheiten und der Gemeinschaftsgrundrechte, Baden-Baden, 2002; G. DAVIES, EU Internal Market Law, Londres, 2002; D. EHLERS (Hrsg.), Europäische Grundrechte und Grundfreiheiten, Berlín, 2003; C. FaulenBach, Der gemeinschaftsrechtliche Vorbehalt im europäischen Wettbewerbsrecht: die Herkunftslandanknüpfung der E-Commerce-Richtlinie unter dem Einfluss der Grundfreiheiten, Frankfurt am Main, 2004; S. FeIDEN, Die Bedeutung der 'Keck'Rechtsprechung im System der Grundfreiheiten: ein Beitrag zur Konvergenz der Freiheiten, Berlín, 2003; W. FrenZ, «Verpflichtungen Privater durch Richtlinien und Grundfreiheiten (Zugleich Anmerkung zu EuGH, Rs. C 397/01 bis C-403/01 [DRK-Urteil])», EWS, 2005, pp. 104-108; R. GRABER, Die unmittelbare Drittwirkung der Grundfreiheiten: eine Untersuchung anhand einer Auslegung des EG-Vertrages, der Rechtsprechung des Gerichtshofes und der Folgen einer angenommenen unmittelbaren Drittwirkung, Munich, 2002; J. GeBauer, Die Grundfreiheiten des EG-Vertrags als Gemeinschaftsgrundrechte, Berlín, 2004; A. Hatje (HrSG.), Das Binnenmarktrecht als Daueraufgabe, Baden-Baden, 2002; St. KADElBACH/N. Petersen, «Europäische Grundrechte als Schranken der Grundfreiheiten. Anmerkung zum EuGH-Urteil in der Rs. C-112/00, Schmidberger/Republik Österreich (Brennerblockade), EuGRZ 2003, 492», EuGRZ, 30, 22/23, 2003, pp. 693-698; K. MoJZEsowICZ, Möglichkeiten und Grenzen einer einheitlichen Dogmatik der Grundfreiheiten, Baden-Baden, 2001; A. MüHL, Diskriminierung und Beschränkung. Grundansätze einer einheitlichen Dogmatik der wirtschaftlichen Grundfreiheiten, Berlín, 2004; R. MuÑOZ, «Le marché intérieur: comment rendre effectifs les droits des intéressés?», Rev.M.C., n. ${ }^{\circ}$ 458, mai 2002, pp. 337-341; M. O'BRIEN, «Company taxation, State aid and fundamental freedoms: is the next step enhanced co-operation?», Eur.L.Rev., 2005, pp. 209-233; K. OTTERSBACH, Rechtsmissbrauch bei den Grundfreiheiten des europäischen Binnenmarktes, BadenBaden, 2001; P. Philip/L. VANHOVE, «Le droit fiscal face aux libertés fondamentales du Traité de 1'Union européenne», Petites affiches, 393, n. ${ }^{\circ}$ 7, 9 janvier 2004, pp. 4-9; ST. PlÖTSCHER, Der Begriff der Diskriminierung im Europäischen Gemeinschaftsrecht: zugleich ein Beitrag zur einheitlichen Dogmatik der Grundfreiheiten des EG-Vertrages, Berlín, 2003; K. PREedy, Die Bindung Privater an die europäische Grundfreiheiten - Zur so genannten Drittwirkung im Europarecht, Berlín, 2005; G. SchIMMING, Konvergenz der Grundfreiheiten des EGV unter besonderer Berücksichtigung mitgliedstaatlicher Einfuhrund Einreisebeschränkungen, Regensburg, Univ., Diss., 2002; D. SCHINDLER, Die Kollision von Grundfreiheiten und Gemeinschaftsgrundrechten. Entwurf eines Kollisionsmodells unter Zusammenführung der Schutzpflichten- und der Drittwirkungslehre, Berlín, 2001; J. SNELL, Goods and services in EC law: a study of the relationship between the freedoms, Oxford, 2002; R. STREINZ, «Anmerkung zu EuGH C-36/02 (Zulässige Beschränkung der Grundfreiheiten; Omega Spielhallen- und Automatenaufstellungs GmbH ./. Oberbürgermeisterin der Bundesstadt Bonn)», JuS, 2005, pp. 64-66; A. TASSIKAS, Dispositives Recht und Rechtswahlfreiheit als Ausnahmebereiche: ein Beitrag zur Privatautonomie, Vertragsgestaltung und Rechtsfindung im Vertragsverkehr des Binnenmarkts, Tübingen, 2004. 
instalación o sede física-económica en otro Estado miembro» ( $\mathrm{CH}$. GAVALDA / G. PARLEANI ${ }^{4}$ ).

4. La libertad de establecimiento cubre diversa posibilidades: a) las sociedades ya existentes en un Estado miembro pueden implantar, en otros países comunitarios, establecimientos secundarios (= sucursales, filiales, agencias); b) o bien pueden trasladar su sede social a otro Estado miembro. Sin embargo, este supuesto (= que no está prohibido ni por el Derecho comunitario ni, en principio, tampoco por los Derechos nacionales), resulta muy oneroso a efectos fiscales: supone pagar los tributos en el país de origen, por la disolución de la sociedad, así como pagar nuevos tributos por creación de una nueva sociedad en el país de acogida. Además, no existe ninguna normativa comunitaria que permita a la sociedad trasladarse de un Estado miembro a otro Estado miembro sin previa extinción de la sociedad originaria (STJCE 27 septiembre 1988, The Queen vs. Treasury and Commissioners of Inland Revenue-ex parte Daily Mail and General Trust plc, 81/87, Rec., p. 5483). El resultado de la situación descrita es que la libertad de establecimiento se ejerce en la UE, en la práctica, bajo la forma del «establecimiento secundario» $\left(\mathrm{X}\right.$. BoucOBZA ${ }^{5}$ ). Se instalan sucursales o filiales en otros Estados miembros y, una vez allí instaladas, la sociedad se lanza a las actividades económicas en el Estado miembro de destino.

5. Las exigencias legales de los Estados miembros que supongan un obstáculo a esta libertad de establecimiento son contrarias al Derecho comunitario. Son nulas e inaplicables. En particular, el TJCE ha eliminado las regulaciones nacionales de los Estados miembros que resultan discriminatorias o que comportan obstáculos para la libertad de establecimiento. Todo comenzó, como es bien sabido, a partir de la STJCE 21 junio 1974, Jean Reyners vs. Bélgica, 2/74, Rec., p. 631 y de la STJCE 3 diciembre 1974, Van Binsbergen vs. Bestuur van de Bedrijfsvereiniging voor de Metaalnijverheid, 33/74, Rec., p. 1299.

6. Sin embargo, la libertad de establecimiento puede resultar «limitada» $\mathrm{u}$ «obstaculizada» como resultado de ciertas exigencias que son «comunitariamente legítimas» (= son «frenos» a la libertad de establecimiento impuestos por los Estados miembros pero justificados incluso por el Derecho comunitario mismo). El TJCE ha creado la noción de límite a la libertad de establecimiento por «razones de interés general». Esta limitación (= que constituye y opera como una especie de cláusula de protección o Schutz-

\footnotetext{
${ }^{4}$ C. Gavalda / G. Parleani, Droit des affaires de l'Union européenne, 4. ${ }^{a}$ ed., Litec, 2002, pp. 67-69.

${ }^{5}$ X. BoucoBZA, L'acquisition internationale de société, 1998, LGDJ, pp. 55-56.
} 
klaussel de la regulación nacional de cada mercado nacional, que es la regla general: STJCE 9 marzo 1999, Centros, FJ 19) no se trata, en realidad, de un «límite» a la libertad de establecimiento. Se trata, más bien, de perfilar el ámbito de aplicación real del art. 49 TCE. Por tanto, una medida restrictiva de la libertad de establecimiento adoptada por un Estado miembro (= como, por ejemplo, los requisitos lingüísticos, exigencias de honorabilidad y deontología, condiciones de la prestación, permisos, autorizaciones para el ejercicio de la actividad, etc.), puede ser considerada «legítima» desde la perspectiva del Derecho comunitario sólo si se verifican las siguientes condiciones.

(a) Debe tratarse de exigencias que afectan, exclusivamente, al libre acceso al ejercicio de la actividad económica. No pueden afectar al desplazamiento o estancia del nacional de un país comunitario en el Estado receptor.

(b) No debe existir armonización legal por normas comunitarias que regulen el acceso a una determinada profesión. En dicho caso, la normativa nacional armonizada o la normativa comunitaria son directamente aplicables. Por tanto, la normativa nacional propia de cada Estado no puede perjudicar la aplicación de la normativa comunitaria.

(c) Las restricciones impuestas por el Estado de acogida no deben comportar discriminación. La medida ha de aplicarse, indistintamente, a todo operador que ejerza la actividad en el territorio del Estado, y no sólo a los sujetos extranjeros o residentes en otros Estados (STJCE 25 julio 1991, Comisión vs. Países Bajos, C-353/89, Rec., p. I-4069; STJCE 4 diciembre 1986, Comisión vs. Alemania, 205/84, Rec., p. 3755; STJCE 26 febrero 1991, Comisión vs. Italia, C-180/89, Rec., p. I-709; STJCE 20 mayo 1992, Claus Ramrath; STJCE 18 marzo 1980, Procureur du Roi vs. Debauve (Coditel I), 52/79, Rec., p. 833; STJCE 12 julio 1997, Comisión vs. Irlanda; STJCE 1 febrero 1996, Proceso penal contra G. Perfili, C-177/94, Rec., p. I161; STJCE 23 noviembre 1999, Arblade \& Leloup, C-369/96 y 376/96, Rec., p. I-8453). Si la medida es discriminatoria, es siempre contraria al Derecho comunitario. Está, de por sí, prohibida.

(d) La restricción debe ser una medida objetivamente necesaria. Deben existir, en el ámbito de la actividad considerada, «razones imperiosas ligadas al interés general» que justifican estas medidas restrictivas (STJCE 3 diciembre 1974, Van Binsbergen vs. Bestuur van de Bedrijfsvereiniging voor de Metaalnijverheid, 33/74, Rec., p. 1299; STJCE 20 mayo 1992, Claus Ramrath, C-106/91, Rec., p. I-3351). La medida ha de ser objetivamente necesaria para garantizar el respeto a esos «intereses generales» (STJCE 4 diciembre 1986, Comisión vs. Alemania, 205/84, Rec., p. 3755; STJCE 26 febrero 1991, Comisión vs. Grecia, C-198/89, Rec., p. I-727; STJCE 20 mayo 1992, Claus Ramrath, C-106/91, Rec., p. I-3351). Para apreciar la concurrencia de una necesidad objetiva de la medida restrictiva, han de tenerse en cuenta tres datos. 
Primero: el interés general no debe hallarse protegido ya por las reglas aplicadas al prestador en el Estado de origen (STJCE 2 junio 1996, Comisión vs. Italia; STJCE 23 noviembre 1999, Arblade \& Leloup, C-369/96 y 376/96, Rec., p. I-8453, STJCE 30 noviembre 1995, R. Gebhard vs. Consiglio dell'Ordine degli avvocati e procuratori di Milano, C-55/94, Rec., p. I4165; STJCE 23 noviembre 1999, Arblade \& Leloup, C-369/96 y 376/96, Rec., p. I-8453). Si la previa aplicación de una normativa por parte del Estado de origen garantiza ya la protección del interés general, no cabe imponer ulteriores restricciones por parte del Estado miembro de destino). Se exige, pues, tal y como ocurre en la libre circulación de mercancías, una cierta «equivalencia» (= o «mismo nivel de protección»), entre la Ley del Estado de origen y la Ley del Estado receptor.

Segundo: la medida nacional restrictiva debe ser necesaria. En otras palabras: el objetivo que persigue no debe poder alcanzarse a través de reglas menos restrictivas: la reglamentación nacional debe ser, pues, necesaria y apropiada al objetivo que se persigue (STJCE 23 noviembre 1999, Arblade \& Leloup, C-369/96 y 376/96, Rec., p. I-8453; STJCE 6 junio 1996, Comisión vs. Italia, C-101/94, Rec., p. I-2691; STJCE 15 mayo 1997, Futura Participations y Singer, C-250/95, Rec., p. I-2471; STJCE 29 noviembre 2001, Coster).

Tercero: la restricción impuesta por la medida nacional del Estado receptor debe ser proporcional al objetivo a defender (STJCE 25 julio 1991, Säger vs. Dennemayer; STJCE 25 julio 1991, Comisión vs. Países Bajos, C-353/89, Rec., p. I-4069; STJCE 12 diciembre 1996, Reisebüro Broede vs. Gerd Sand$k e r)$. Esta exigencia es propia de toda construcción jurisprudencial o pretoriana (V. Hatzopoulos). Pero ¿cómo se mide la «proporcionalidad»? El TJCE emplea varios parámetros para decidir si la medida es o no es «proporcional»: (a) naturaleza del servicio: si el servicio ofrecido por el prestador comunitario es un servicio general y no específico, el beneficiario del servicio no puede esperar prestaciones específicas (= que le podrían ser proporcionadas por los prestadores del Estado de acogida), sino prestaciones generales, por lo que no existe «proporcionalidad»; (b) consecuencias que se derivan del servicio general ofrecido por el prestador comunitario: si la falta de prestaciones específicas por parte del prestador comunitario no perjudica el objetivo a defender (= la exigencia imperativa), entonces la medida no es proporcional; (c) existencia de recursos: si la medida nacional restrictiva no es susceptible de recurso, normalm3ente jurisdiccional, de modo que los interesados (= los prestadores comunitarios de servicios) pueden recurrir contra las medidas presumiblemente restrictivas, entonces no es proporcional. De acuerdo con estos criterios, por ejemplo, una medida es «proporcional» cuando no impide totalmente la realización de una actividad en el Estado receptor, sino que la «canaliza» a través de ciertas exigencias justificadas (STJCE 21 octubre 1999, Questore di Verona vs. Diego Zenatti, C-67/98, Rec., p. I7289; STJCE 12 diciembre 1996, Reisebüro Broede vs. Gerd Sandker). 
7. La cláusula del «interés general» como límite a la libertad de establecimiento y a otras libertades comunitarias ha generado una «jurisprudencia casuística». Sigue un modelo anglosajón. No hay reglas generales ni reglas a priori. Las reglas se van construyendo con la acumulación de casos fallados por el TJCE. Se decide, caso por caso, si la legislación restrictiva del Estado de acogida es admisible o no lo es en virtud de la defensa de este «interés general». La lista de razones de interés general está siempre abierta. Varios ejemplos de supuestos en los que ha operado el «interés general» como límite a la libertad de establecimiento y a la libre prestación de servicios pueden citarse: la protección de los destinatarios del servicio y los consumidores a través de normas profesionales, la protección de la propiedad intelectual, protección de los trabajadores, la conservación del patrimonio histórico artístico nacional, y mejor difusión de los conocimientos relativos a dicho patrimonio, así como la defensa de la política cultural, la protección de las reglas sobre cualificación y deontología profesional, la coherencia del sistema fiscal del Estado donde se presta el servicio, la protección del principio de confianza financiera y defensa de la reputación del mercado nacional, la defensa del medio ambiente, la defensa de una lengua o cultura, la seguridad en las carreteras, el mantenimiento de un equilibrio financiero $y$ deportivo entre los clubs deportivos, etc.

8. Una vez que una empresa se ha «establecido en otro Estado miembro, la actividad económica que tal empresa va a desplegar en dicho Estado está sujeta a los requisitos legales impuestos por el Estado receptor (= «Estado miembro de destino» o «Estado de acogida»). Aunque algunos sectores de la actividad económica de las empresas están regulados por «normas armonizadas» de Derecho comunitario, la mayor parte de las actividades empresariales las regula cada Estado miembro como tiene por conveniente (= Estado miembro por Estado miembro, la regulación legal es diferente).

\section{Sociedades titulares del derecho a la libertad de establecimiento en la UE}

9. Para beneficiarse de la libertad de establecimiento, las personas jurídicas, y en particular, las sociedades de capital, deben satisfacer, cumulativamente, dos requisitos: $1^{\circ}$ ) la sociedad debe haber sido «constituida de conformidad con la legislación de un Estado miembro»; 2. ${ }^{\circ}$ ) la sociedad debe tener su sede social, administración central o centro de actividad principal en un Estado miembro. Ambos requisitos (= y ninguno más, conviene recordarlo desde este momento), se encuentran recogidos en el art. 48 TCE.

Ningún otro requisito más se exige. Por ejemplo: no se requiere, digan lo que digan ciertos autores, que la sociedad ejerza «alguna actividad económica» en el Estado miembro donde tiene su domicilio estatutario (STJCE 9 marzo 1999, Centros; STJCE 5 noviembre 2002, Überseering; STJCE 30 septiembre 2003, Inspire Art). 
Como es fácil apreciar, si se hace zoom detenidamente sobre el art. 48 TCE, se descubre, como explica H. MUIR-WATT, que el precepto no señala cuál es la «Ley aplicable» a las personas jurídicas 6 . Ésta es una cuestión que deben decidir y determinar las normas de conflicto de los Estados miembros. Éstos, en principio, pueden elegir la tesis o el criterio de conexión que prefieran. Pueden optar por la «tesis de la sede real» o por la «tesis del domicilio social» o por la «tesis de la sede de explotación»o por la «tesis de la Incorporación», o por cualquier otra que estimen conveniente. Ya lo dijo bien claro la STJCE 27 septiembre 1988, The Queen vs. Treasury and Commissioners of Inland Revenue-ex parte Daily Mail and General Trust plc, 81/87, Rec., p. 5483, y lo corroboró con toda nitidez años más tarde el TJCE mismo en las STJCE 9 marzo 1999, Centros, STJCE 5 noviembre 2002, Überseering, STJCE 30 septiembre 2003, Inspire Art. En suma, como bien indica P. BlanCo-Morales LiMONES, el art. 48 TCE no es una norma de conflicto y en nada obliga a los Estados miembros a seguir una u otra teoría para fijar la Ley aplicable a las sociedades ${ }^{7}$.

Normalmente, suelen coincidir el Estado conforme a cuyas leyes se ha constituido la persona jurídica con el Estado de su sede social (= sede fijada en los estatutos de la sociedad), con el Estado donde la sociedad realiza la mayor parte de sus actividades económicas (= llamado por ciertos autores, el país de su «sede real») y con el Estado en el que la sociedad tiene su centro de dirección efectivo (= también llamado por otros autores, para aumentar la confusión ya alarmante sobre este tema, el país de su «sede real»). Pero cuidado: esto no siempre es así. Puede que una sociedad constituida con arreglo al Derecho inglés y con sede estatutaria en Londres despliegue la inmensa mayoría de sus actividades económicas, o todas, en Holanda y sea dirigida también desde Holanda. Naturalmente, los ejemplos pueden multiplicarse. La realidad siempre supera a la ficción. Lo demuestra la sentencia del BayObLG (Tribunal Superior de Baviera) de 23 febrero 2003: una sociedad constituida con arreglo a la Ley de la República de Zambia era dirigida y controlada desde Alemania y desarrollaba actividades en varios países comunitarios y no comunitarios $^{8}$. Dicha sociedad no se beneficia de la libertad de establecimento porque se constituyó con arreglo a la Ley de un tercer Estado.

10. Así pues, basta con que la sociedad tenga en un Estado miembro su centro de explotación principal (= lugar donde desarrolla principalmente sus actividades económicas), o su sede estatutaria (= lugar mencionado como

${ }^{6}$ H. MuIR-WaTt, «Nota a STJCE 30 septiembre 2003, Inspire Art», RCDIP, 2004, pp. 173-184, esp. p. 176.

${ }^{7}$ P. Blanco-Morales Limones, Transferencia internacional de sede social, Pamplona, 1997, pp. 51-59.

${ }^{8} R I W, 2003$, p. 387. 
sede de la sociedad en sus estatutos), o su administración central (= lugar donde la sociedad tiene su centro de dirección efectivo). Estos tres son criterios alternativos. Uno de ellos debe concurrir junto al otro requisito obligatorio: que la sociedad se haya constituido con arreglo a la legislación material de un Estado miembro. Por ello, no se benefician de la libertad de establecimiento ni de la libre prestación de servicios las sociedades radicadas en un «tercer país» que dispongan de sucursales o agencias situadas en países comunitarios, pero que no se han constituido con arreglo a la Ley de un Estado miembro. Una vez que concurren las exigencias del art. $48 \mathrm{TCE}$, la sociedad se beneficia de la libertad de establecimiento y es irrelevante el país, comunitario o no, donde radica la sede real de la sociedad (= el país donde despliega sus actividades económicas). Una vez corroborado que la sociedad constituida con arreglo al Derecho de un Estado miembro tiene su sede estatutaria o su administración central o su sede real en un Estado miembro, es ya una sociedad que puede beneficiarse de la libertad de establecimiento en los demás Estados miembros.

11. Hasta aquí lo que dice, por cierto, de modo totalmente diáfano, el art. 48 TCE. Y a partir de aquí comienzan las discrepancias doctrinales. Ciertos autores se muestran alarmados frente a varios «supuestos riesgos» que genera la redacción del art. 48 TCE.

12. a) Penetración en la UE de sociedades no comunitarias. Tal y como está redactado el art. 48 TCE, se genera un riesgo enorme, afirman determinados autores. En efecto: basta una mínima implantación, incluso nominal, de una sociedad en un Estado miembro, para que dicha sociedad (= una sociedad que es, realmente, una sociedad no integrada en el mercado comunitario) se beneficie de la libertad de establecimiento en la UE. Cabría así pensar en una sociedad con una mera sede estatutaria en un Estado miembro, pero con sede real en un tercer Estado no comunitario o plenamente controlada por nacionales de terceros Estados. En dicho caso, tal sociedad se beneficiaría de la libertad de establecimiento y penetraría con total libertad en el mercado comunitario. Pero que no cunda el pánico: este riesgo y estos temores son totalmente infundados. Varias razones lo explican (L. LÉvY ${ }^{9}$ ). Primero, debe recordarse que, a pesar de opiniones contrarias muy arraigadas en un pensamiento agresivo contra la libre circulación de capitales, como la de J. BÉGUIN ${ }^{10}$, el capital no tiene «nacionalidad». Por ello, no tiene sentido poner frenos a la libre movilidad de una sociedad en la UE sólo por el

\footnotetext{
${ }^{9}$ L. LÉVy, La nationalité des sociétés, LGDJ, 1984, pp. 67-69.

10 J. BÉGUIN, «La nationalité juridique des sociétés devrait correspondre á leur nationalité économique», en AA.VV., Le droit privé français à la fin du XXe siècle, Études offertes à E. Catala, 2001, Litec, pp. 859-874.
} 
hecho de que el capital está en manos de nacionales de terceros Estados. Eso recuerda la antigua «teoría del control», propia de tiempos de guerra, pero poco adecuada en un mercado único (B. AUDIT ${ }^{11}$ ). Segundo, si la sociedad está de algún modo implantada en un Estado miembro y se ha constituido con arreglo a la Ley de un Estado miembro, ya está contribuyendo con ello al crecimiento y a la competencia en el contexto de la economía de la UE. Bienvenida sea, pues, dicha sociedad, al mercado comunitario. Ya puede circular libremente por la UE, y ejercer sus actividades económicas en todos los Estados miembros en régimen de libertad de establecimiento (E. BLAN$\left.\mathrm{QUET}^{12}\right)$.

13. b) Sociedades con sede estatutaria en un Estado miembro pero con sede real en otro Estado miembro: el fantasma del fraude provocado por las Pseudo-Foreign Corporations o sociedades ficticias. Ciertos autores, fascinados por la tesis de la sede real (= en la versión según la cual la «sede real» equivale a «lugar principal de explotación»), no comprenden ni están dispuestos a aceptar que una sociedad pueda haberse constituido con arreglo a un Estado miembro «A»y tenga en «A» su sede estatutaria, pero despliegue sus actividades principales en otro Estado miembro «B». Detrás de ello ven el fantasma del fraude. Los argumentos que citan en favor de esta «tesis antifraude» son los siguientes: $1^{\circ}{ }^{\circ}$ ) el fraude está prohibido en Derecho comunitario y ha sido castigado por el TJCE cuando una sociedad se instala de modo puramente ficticio en un Estado miembro pero dirige todas sus actividades hacia otro Estado miembro. En apoyo de este presunto argumento, estos autores suelen citar las afirmaciones contenidas en la STJCE 5 octubre 1994, TV10, asunto C-23/93, Rec., p. I-4795: el TJCE admitió la aplicación de las normas del país de destino de unas emisiones de TV, porque la sociedad emitente disponía de un «establecimiento salvaje» en otro Estado miembro, cuyo único objetivo era transmitir señales de TV al primer Estado miembro y no a ningún otro Estado miembro, incluido el Estado miembro desde donde se emitían las señales. Estos autores emplean la «analogía»: visto lo visto en la STJCE 5 octubre 1994, TV10, asunto C-23/93, tampoco debe ser posible que una sociedad instale una «sede ficticia» $\mathrm{o}$ «puramente nominal» en un Estado miembro para que luego toda la actividad social se desarrolle en «otro» Estado miembro. En dicho caso, las normas del Estado miembro «de destino» deben aplicarse (= es el país de la sede «real» de la sociedad); $2^{\circ}$ ) para que una sociedad pueda considerarse «establecida» en un Estado miembro (= y pueda así beneficiarse de la libertad de establecimiento), dicha sociedad debe presentar un «ligamen efectivo y continuo con la economía de

${ }^{11}$ B. Audit, Droit international privé, Economica, París, 4. a ed., 2006, pp. 868-869.

${ }^{12}$ E. BLANQUET, Les fusions transfrontaliéres et la mobilité des sociétés, Rev. Soc., 2000, pp. 115-133. 
un Estado miembro». Esta tesis fue recogida en el Programa General para la supresión de las restricciones a la libertad de establecimiento, de fecha 18 diciembre 1961. Estos autores estiman que la sociedad internacionaliza fraudulentamente un supuesto meramente interno (= la sociedad está objetiva y exclusivamente conectada con el Estado miembro de destino en el que ejerce sus actividades económicas, pero la sede estatutaria se ha «colocado» en otro Estado miembro diferente con arreglo a cuyas leyes societarias se ha constituido tal sociedad).

14. Pues bien: esta «corrección» de la libertad de establecimiento en favor de la exigencia para las sociedades de un «ligamen efectivo y continuo con la economía de un Estado miembro» revela temores plenamente infundados. El fantasma del fraude, como indica M. MENJuCQ, es sólo eso: un fantasma, un espectro ${ }^{13}$. Y como es bien sabido, los fantasmas no existen. Varias razones permiten desechar estos miedos y, con ello, es posible también desechar sin dificultades esta «corrección artificial» añadida erróneamente al art. 48 TCE por ciertos autores ${ }^{14}$.

1..$\left.^{\circ}\right)$ No debe olvidarse que el art. $48 \mathrm{TCE}$ (= que nada dispone al respecto pudiendo perfectamente haberlo hecho), nada exige en relación con ese inexacto e indeterminado «ligamen efectivo y continuo». Se exige lo que se exige y nada más. In claris non fit interpretatio.

2. $\left.{ }^{\circ}\right)$ Los Programas generales de 1961 son textos que carecen de contenido normativo directo. Son meras «indicaciones útiles con miras a la realización de las disposiciones correspondientes del Tratado» (= en palabras de la STJCE 28 abril 1977, Jean Thieffry vs. Conseil de l'ordre des avocats à la cour de Paris, 71/76, Rec., p. 765). Por tanto, difícilmente pueden ser utilizados para «corregir» el tenor literal, clarísimo, del art. 48 TCE. Pero resulta que, además, y aquí llega lo decisivo, estos «Programas» no fueron diseñados para los casos totalmente intracomunitarios (= casos cuya totalidad de

${ }^{13}$ M. MenJuCQ, «Nota a STJCE 23 septiembre 2003, Inspire Art», JDI Clunet, 2004, pp. 917-929, esp. p. 926; ID., Droit international et européen des sociétés, Montchrestien, 2001, pp. 23-24.

${ }^{14}$ Es el caso, entre otros, de S. SÁNCHEZ LoREnZo, «El Derecho de establecimiento secundario de las sociedades ficticias en el ámbito comunitario», Libro homenaje al Prof. Sanchez Calero, 2002, pp. 451 y ss.; ID., «El Derecho europeo de sociedades y la sentencia Centros: la relevancia de la sede real en el ámbito comunitario», Anuario Español de Derecho internacional privado, núm.0, 2000, pp. 115-157; ID., Derecho privado europeo, Granada, Ed. Comares, 2002, pp. 32-33; ID., «Nota a la sentencia TJCE de 5 de noviembre de 2002, As. C-208/00: Überseering», REDI, 2002-2, pp. 927-930; ID., «What Do We Mean when We Say 'Folklore'? Cultural and Axiological Diversities as a Limit for a European Private Law», European Review of Private Law, 2006, 2, pp. 197-219, esp. pp. 205-207; D. SANCHO VILLA, «La dudosa compatibilidad con el Derecho comunitario de la costrucción del Tribunal de Justicia de la Comunidad Europea en la sentencia Centros Ltd», La Ley, 1999, D-297, pp. 1851-1859; ID., La transferencia internacional de la sede social en el Espacio Europeo, 2001. 
elementos están localizados en la UE). Fueron diseñados, por el contrario, y como bien recuerda P. KINDLER, con el solo objetivo de atajar prácticas de «establecimiento salvaje» en la UE por parte de sociedades realmente radicadas en terceros Estados no comunitarios ${ }^{15}$. Así lo indica con meridiana claridad la STJCE 5 noviembre 2002, Überseering FJ 75: «[d]el propio tenor del Programa general se deduce que sólo exige una vinculación efectiva y continua en el caso en el que la sociedad sólo tenga su domicilio social estatutario en el interior de la Comunidad». Es decir, la sede real en un Estado miembro sólo sería exigible como requisito de la libertad de establecimiento cuando la sociedad dispusiera de su sede estatutaria, puramente nominal en la UE, pero su sede real (= actividades económicas principales o relevantes), estuviera localizada fuera de la UE. Por tanto, si una sociedad dispone de su sede estatutaria en un Estado miembro en el que no ejerce actividad económica alguna, y desarrolla tales actividades económicas en otro Estado miembro, el llamado «Programa General» es inaplicable. Así de simple (F. J. GARCIMARTín AlFÉREZ ${ }^{16}$ ).

3. $\left.{ }^{\circ}\right)$ Estos autores emplean un concepto impreciso y nebuloso, el concepto de «ligamen efectivo y continuo con la economía de un Estado miembro». Dicho concepto no es más que una «tapadera», una «máscara», un maquillaje cuyo secreto objetivo es intentar volver a la vida la tesis de la «sede real» en el art. 48 TCE. Una tesis que puede se calificada, en palabras con P. BEHRENS, como «una tesis arcaica, que no asegura la protección eficaz de los acreedores y que es una especie de proteccionismo propio del período de entreguerras y un obstáculo a la integración europea» ${ }^{17}$. Pero es que resul-

${ }^{15} \mathrm{P}$. KINDLER, «Aspetti essenziali di un futuro regolamento comunitario sulla legge applicabile alle società», RDIPP, 2006-III, pp. 657-674, esp. p. 659.

${ }^{16}$ Las enormes debilidades de las tesis anti-fraude son puestas de manifiesto con muy buen criterio por F. J. GARCIMARTín AlfÉREZ, «La Sitztheorie es incompatible con el Tratado CE (algunas cuestiones del Derecho internacional de sociedades iluminadas por la sentencia TJCE de 9 de marzo de 1999)», RDM, 1999, pp. 645 y ss.; ID., «La Sentencia 'Centros': el 'status questionis' un año después», Not.UE, n. ${ }^{\circ} 195,2001$, pp. 79-96; ID., «La sentencia Centros del Tribunal de Justicia de las Comunidades Europeas: una visión a través de los comentarios», Revista Electrónica de Estudios Internacionales, 2000, pp. 2-ss.; ID., «La sentencia 'Überseering' y el reconocimiento de sociedades extranjeras: se podrá decir más alto, pero no más claro», $R D M$, n. 248, 2003, pp. 663-682.

${ }^{17}$ P. BEHRENS, «Das Internationale Gesellschaftsrecht nach dem Überseering-Urteil des EuGH und den Schlussanträgen zu Inspire Art», IPRax, 23, 3, 2003, pp. 193-207, esp. p. 206; ideas similares en P. BEHRENS, «Das Internationale Gesellschaftsrecht nach dem Centros-Urteil des EuGH», IPrax, 1999, pp. 323-339; ID., «Der Duchgriff über die Grenze», RabelsZ, 1982, pp. 308-321; ID., «Identitätswahrende Sitzverlegung einer Kapitalgesellschaft von Luxemburg in die Bundesrepublik Deutschland», RIW, 1986, pp. 590-599; ID., «Die Umstrukturierung von Unternehmen durch Sitzvelegung oder Fusion über die Grenze im Licht der Niederlassungsfreiheit im Europäischen Binnenmarkt (Art. 52 und 58 EWGV)», ZGR, 1994, pp. 1-32; ID., «Das Internationale Gesellschaftsrecht nach dem Centros-Urteil des EuGH», IPRax, 1999, pp. 323-341. 
ta, además, que, como ha subrayado B. LECOURT, los redactores de dicho precepto, perfectamente conscientes de que podían haber optado por la «tesis de la sede real» para precisar el ámbito de aplicación de la libertad de establecimiento, prefirieron «otro modelo» ${ }^{18}$. El modelo elegido fue un modelo que favorece la movilidad de las sociedades en la UE (= el cambio de sede real no implica cambio de la Ley aplicable que rige la vida interna de sociedad). Un modelo que potencia la elección de la Ley de aquellos Estados miembros que disponen de legislaciones societarias más competitivas $(=10 \mathrm{~s}$ socios no constituirán sus sociedades con arreglo a las Leyes de los Estados miembros que les «penalicen»). Por otro lado, el concepto de «ligamen efectivo y continuo con la economía de un Estado miembro» es, como ya se ha avanzado, un concepto impreciso y nebuloso. Para concretarlo, se precisaría un acuerdo interestatal sobre qué debe entenderse por tal «ligamen efectivo y continuo con la economía de un Estado miembro». Y dicho acuerdo, si es que fuera posible (= lo que resulta muy dudoso), y conveniente (= que no lo es), dista mucho de ser pacífico.

4. $\left.{ }^{\circ}\right)$ Estos autores emiten, sin decirlo expresamente, un juicio condenatorio de ciertas legislaciones societarias de los Estados miembros (= se consideran «Leyes injustas»). Estos autores creen que existen «Leyes societarias buenas» $\mathrm{y}$ «Leyes societarias malas» en los distintos Estados miembros. Este punto de partida es inaceptable. La UE constituye hoy mucho más que un mero y simple «mercado interior». La UE es también un «espacio de libertad, de seguridad y de justicia» (art. 61 TCE), en cuyo contexto resulta muy difícil admitir y aceptar que la legislación societaria de un Estado miembro es una «Ley injusta» (= un «estatuto odioso»). Los Estados miembros son Friendly States. Por ello, el art. 48 TCE «no levanta el velo» de la Ley material de los Estados miembros. En efecto, el hecho de que la sociedad se haya constituido con arreglo a la Ley de un Estado miembro y que tenga su sede estatutaria en un Estado miembro es ya garantía suficiente de que tal sociedad está suficientemente «vinculada con la UE» y de que puede beneficiarse de la libertad de establecimiento. Si la UE es algo más que la «suma aritmética» de ciertos países (=y, ciertamente, es algo mucho más que una mera agregación cuantitativa de países «extraños entre sí»), la integración jurídica europea significa que los «juicios valorativos negativos» contra Leyes de «Estados compañeros» deben estar excluidos y proscritos. Como lo están, por cierto, en el contexto de los supuestos de Derecho interregional ${ }^{19}$.

18 B. LECOURT, L'influence du droit communautaire sur la constitution des groupements, 2000, LGDJ, 2000, pp. 45-46.

${ }^{19} \mathrm{El}$ art. 16.2 del Código Civil español indica: «[1]os conflictos de leyes que puedan surgir por la coexistencia de distintas legislaciones civiles en el territorio nacional se resolverán según las normas contenidas en el capítulo IV con las siguientes particularidades: (...) 2. ${ }^{\circ}$ No será aplicable lo dispuesto en los apartados 1, 2 y 3 del artículo 12 sobre calificación, remisión y orden público». 
$\left.5^{\circ}{ }^{\circ}\right)$ Admitir un criterio riguroso de «establecimiento en la UE» vertebrado por un criterio de «sede real», camuflado tras un maquillaje jurídico en forma de «ligamen continuo y efectivo», conduce a una interpretación restrictiva de los sujetos que puede beneficiarse de la libertad de establecimiento. $Y$ una libertad comunitaria interpretada en sentido restrictivo deja ver la larga mano del dirigismo económico y del estatalismo totalitario contrario a la libre competencia en el mercado. Una interpretación restrictiva de los derechos y de las libertades comunitarias no encaja bien con la construcción europea como «espacio de libertad».

6. $^{\circ}$ ) La analogía de los casos de Pseudo-Foreign Corporations con el caso resuelto por el TJCE en la STJCE 5 octubre 1994, TV10, asunto C-23/93, Rec., p. I-4795, es falsa e inexistente. No hay analogía, pese a la vehemencia mostrada por ciertos autores ${ }^{20}$. La repetición o insistencia en ciertos argumentos no los convierte, por supuesto, en argumentos «convincentes». Son sólo argumentos erróneos repetidos hasta la saciedad. Como escribe H. MuIR-WATT ${ }^{21}$, en el caso de la STJCE 5 octubre 1994, TV10, el TJCE declara que las reglas jurídicas del Estado miembro de destino pueden aplicarse porque regulan las «condiciones de acceso de las sociedades extranjeras a la actividad del mercado local» (= condiciones que corresponde regular al Derecho del Estado miembro de destino). Son «normas relativas al ejercicio de determinadas actividades profesionales» (STJCE 9 marzo 1999, Centros FJ 26). Sin embargo, en los casos de la trilogía jurisprudencial societaria del TJCE, las normas cuya aplicación invocan con desesperación ciertos Estados miembros de destino no regulan tales «condiciones de acceso a la actividad económica en el Estado miembro de destino». Por el contrario, tales normas afectan, y niegan, «las condiciones mismas de la constitución de las sociedades extranjeras» (= son «normas que regulan la constitución de sociedades» en palabras de la STJCE 9 marzo 1999, Centros, FJ 26). Y claro, exigir que las sociedades que van a ejercer actividades eco-

${ }^{20}$ Insiste y persiste en este error, con reiteración e intensidad, S. SÁNCHEZ LORENZO, «El Derecho de establecimiento secundario de las sociedades ficticias en el ámbito comunitario», Libro homenaje al Prof. Sanchez Calero, 2002, pp. 451 y ss.; ID., «El Derecho europeo de sociedades y la sentencia Centros: la relevancia de la sede real en el ámbito comunitario», Anuario Español de Derecho internacional privado, núm. 0, 2000, pp. 115-157; ID., Derecho privado europeo, Granada, Ed. Comares, 2002, pp. 32-33. También, en la misma línea equivocada del autor anterior, se sitúa D. SANCHO VILLA, «La dudosa compatibilidad con el Derecho comunitario de la construcción del Tribunal de Justicia de la Comunidad Europea en la sentencia Centros Ltd», La Ley, 1999, D-297, pp. 1851-1859; ID., La transferencia internacional de la sede social en el Espacio Europeo, 2001, passim, insistiendo en estas equivocadas construcciones. Por cierto, muy justamente criticadas por F. J. GARCIMARTíN ALFÉREZ, «La sentencia 'Überseering' y el reconocimiento de sociedades extranjeras: se podrá decir más alto, pero no más claro», $R D M$, n. 248, 2003, pp. 663-682.

${ }^{21}$ H. MuIR-WATT, «Nota a STJCE 30 septiembre 2003, Inspire Art», RCDIP, 2004, pp. 173-184, esp. p. 180. 
nómicas en el Estado miembro de destino se «adapten» al, y «respeten» el Derecho societario del Estado miembro de destino significa que sólo las sociedades que se constituyen con arreglo a tal Derecho societario del Estado miembro de destino pueden disfrutar de la libertad de establecimiento. Lo cual es desproporcionado, innecesario, reglamentista, imperialista, excesivo y atenta contra la existencia misma o «esencia», como dice el TJCE, de la libertad de establecimiento. Así, de modo radical, la STJCE 5 noviembre 2002, Überseering FJ 81 y 93, indica que «[l]a exigencia de reconstitución de la misma sociedad en Alemania [Estado miembro de destino en el caso de esta sentencia] equivale, en consecuencia, a la negación misma de la libertad de establecimiento». Los autores que ven el fantasma del fraude por todas partes, asustados no se sabe bien por qué, no captan la sutileza de esta importante distinción. Ello se debe a una falta de profundidad en el estudio y en la comparación entre el caso objeto de la STJCE 5 octubre 1994, TV10, por un lado, y los tres grandes casos societarios objeto de las STJCE 9 marzo 1999, Centros, STJCE 5 noviembre 2002, Überseering, STJCE 30 septiembre 2003, Inspire Art. Por eso la analogía de la que alardean estos autores es falsa y su argumentación se convierte en una falacia: la famosa «falacia de la falsa analogía» o «falacia de Van Gogh».

7. $\left.{ }^{\circ}\right)$ Como ha puesto de relieve O. VAN Solinge, los partidarios de la tesis de la «sede real camuflada» (= que niegan radicalmente, aunque con argumentos poco creíbles y nada convincentes, como se ha visto, la posibilidad de las sociedades de instalar su sede estatutaria en un Estado miembro y de desplegar todas sus actividades económicas en otro Estado miembro) practican un «proteccionismo larvado» ${ }^{22}$. En efecto: si la sociedad no dispone de total movilidad en la UE, se verá forzada a «adaptarse» a los tipos societarios de cada uno de los Estados miembros, sin posibilidad de elegir el tipo societario más ventajoso de entre los que ofrecen los Derechos de los Estados miembros. Ello incrementa la necesidad de una colaboración con el «empresario local». Ahí radica el proteccionismo.

15. Como se verá más adelante, el TJCE ha rechazado radicalmente la errónea tesis según la cual se produce fraude si una sociedad instala una sede social en un Estado miembro pero ejerce la mayor parte o todas sus actividades económicas en otro Estado miembro. Así puede apreciarse en la famosa trilogía societaria formada por las sentencias STJCE 9 marzo 1999, Centros, STJCE 5 noviembre 2002, Überseering, STJCE 30 septiembre 2003, Inspire Art.

22 O. VAN Solinge, «Cross-border Mergers: a Private International Law Approach», Netherlands International Law Review, 1996, pp. 100-104. 


\section{La regulación jurídica de las sociedades en la UE y en los Estados miembros}

16. La UE ha puesto en marcha un proceso de armonización jurídica de la legislación de los Estados miembros relativa a las sociedades. Como muestra el excelente panorama normativo ofrecido por E. NACHTER / M. RAAIJMARKERS ${ }^{23}$, este proceso ha afectado a la regulación legal interna de las sociedades $^{24}$, al Derecho del Mercado de Valores ${ }^{25}$ y al Derecho Fiscal

${ }^{23}$ E. NACHTER / M. RAAIJMARKERS, Harmonization of Company and securities law (The European and American approach), Tilbury, 1989, pp. 19-39. Aunque esta obra es anterior a muchos de los desarrollos normativos del Derecho comunitario acaecidos posteriormente, su planteamiento resulta muy esclarecedor.

${ }^{24}$ Las Directivas comunitarias que armonizan la legislación de los Estados miembros en materia societaria son las siguientes: a) Primera Directiva 68/151/CEE del Consejo, de 9 de marzo de 1968, tendente a coordinar, para hacerlas equivalentes, las garantías exigidas en los Estados miembros a las sociedades definidas en el segundo párrafo del artículo 58 del Tratado, para proteger los intereses de socios y terceros (DOCE L 65 de 14 marzo 1968); b) Segunda Directiva 77/91/CEE del Consejo, de 13 de diciembre de 1976, tendente a coordinar, para hacerlas equivalentes, las garantías exigidas en los Estados miembros a las sociedades, definidas en el párrafo segundo del artículo 58 del Tratado, con el fin de proteger los intereses de los socios y terceros, en lo relativo a la constitución de la sociedad anónima, así como al mantenimiento y modificaciones de su capital (DOCE L 26 de 31 enero 1977); c) Tercera Directiva 78/855/CEE del Consejo, de 9 de octubre de 1978, basada en la letra g del apartado 3 del artículo 54 del Tratado y relativa a las fusiones de las sociedades anónimas (DOCE L 295 de 20 octubre 1978); d) Cuarta Directiva 78/660/CEE del Consejo, de 25 de julio de 1978, basada en la letra g del apartado 3 del artículo 54 del Tratado y relativa a las cuentas anuales de determinadas formas de sociedad (DOCE L 222 de 14 agosto 1978); e) Sexta Directiva 82/891/CEE del Consejo, de 17 de diciembre de 1982, basada en la letra g del apartado 3 del artículo 54 del Tratado y referente a la escisión de sociedades anónimas (DOCE L 378 de 31 diciembre 1982); f) Séptima Directiva 83/349/CEE del Consejo, de 13 de junio de 1983, basada en la letra g del apartado 3 del artículo 54 del Tratado, relativa a las cuentas consolidadas (DOCE L 193 de 18 julio 1983); g) Undécima Directiva 89/666/CEE del Consejo, de 21 de diciembre de 1989, relativa a la publicidad de las sucursales constituidas en un Estado miembro por determinadas formas de sociedades sometidas al Derecho de otro Estado (DOCE L 395 de 30 diciembre 1989); h) Duodécima Directiva 89/667/CEE del Consejo, de 21 de diciembre de 1989, en materia de derecho de sociedades, relativa a las sociedades de responsabilidad limitada de socio único (DOCE L 395 de 30 diciembre 1989); i) Directiva 2006/43/CE del Parlamento Europeo y del Consejo, de 17 de mayo de 2006, relativa a la auditoría legal de las cuentas anuales y de las cuentas consolidadas, por la que se modifican las Directivas 78/660/CEE y 83/349/CEE del Consejo y se deroga la Directiva 84/253/CEE del Consejo (DOUE L 157 de 9 junio 2006). En proyecto o en estudio se hallan otras Directivas sobre materias diversas relativas al régimen jurídico interno de las sociedades. Tales textos abordan cuestiones como la estructura de los órganos de las sociedades anónimas, sus poderes y obligaciones de sus órganos, grupos de sociedades, etc. Muchas duermen desde hace décadas el sueño de los justos y su futuro es incierto, por no decir, poco esperanzador.

${ }^{25}$ La normativa comunitaria más destacable en lo que se refiere al Derecho del Mercado de Valores es la siguiente: a) Directiva 85/611/CEE del Consejo, de 20 de diciembre de 1985, por la que se coordinan las disposiciones legales, reglamentarias y administrativas 
Societario ${ }^{26}$, así como a ciertos aspectos netamente internacionales de la actividad societaria en la $\mathrm{UE}^{27}$.

sobre determinados organismos de inversión colectiva en valores mobiliarios (OICVM) (DOCE L 375 de 31 diciembre 1985), Directiva profusa y sucesivamente modificada; b) Directiva 93/22/CEE del Consejo, de 10 de mayo de 1993, relativa a los servicios de inversión en el ámbito de los valores negociables (DOCE L 141 de 11 junio 1993); c) Directiva 2001/34/CE del Parlamento Europeo y del Consejo, de 28 de mayo de 2001, sobre la admisión de valores negociables a cotización oficial y la información que ha de publicarse sobre dichos valores (DOCE L 184 de 6 julio 2001); d) Directiva 2002/87/CE del Parlamento Europeo y del Consejo, de 16 de diciembre de 2002, relativa a la supervisión adicional de las entidades de crédito, empresas de seguros y empresas de inversión de un conglomerado financiero, y por la que se modifican las Directivas 73/239/CEE, 79/267/CEE, 92/49/CEE, 92/96/CEE, 93/6/CEE y 93/22/CEE del Consejo y las Directivas 98/78/CE y 2000/12/CE del Parlamento Europeo y del Consejo (DOUE L 35 de 11 febrero 2003); e) Directiva 2003/6/CE del Parlamento Europeo y del Consejo, de 28 de enero de 2003, sobre las operaciones con información privilegiada y la manipulación del mercado (abuso del mercado) (DOUE L 96 de 12 abril 2003); f) Directiva 2003/71/CE del Parlamento Europeo y del Consejo, de 4 de noviembre de 2003, sobre el folleto que debe publicarse en caso de oferta pública o admisión a cotización de valores y por la que se modifica la Directiva 2001/34/CE (DOUE L 345 de 31 diciembre 2003); g) Directiva 2003/124/CE de la Comisión, de 22 de diciembre de 2003, a efectos de la aplicación de la Directiva 2003/6/CE del Parlamento Europeo y del Consejo sobre la definición y revelación pública de la información privilegiada y la definición de manipulación del mercado (DOUE L 339 de 24 diciembre 2003); h) Directiva 2003/125/CE de la Comisión, de 22 de diciembre de 2003, a efectos de la aplicación de la Directiva 2003/6/CE del Parlamento Europeo y del Consejo sobre la presentación imparcial de las recomendaciones de inversión y la revelación de conflictos de intereses (DOUE L 339 de 24 diciembre 2003); i) Directiva 2004/39/CE del Parlamento Europeo y del Consejo, de 21 de abril de 2004, relativa a los mercados de instrumentos financieros, por la que se modifican las Directivas 85/611/CEE y 93/6/CEE del Consejo y la Directiva 2000/12/CE del Parlamento Europeo y del Consejo y se deroga la Directiva 93/22/CEE del Consejo (DOCE L 145 de 30 abril 2004); j) Directiva 2004/72/CE de la Comisión, de 29 de abril de 2004, a efectos de aplicación de la Directiva 2003/6/CE del Parlamento Europeo y del Consejo en lo relativo a las prácticas de mercado aceptadas, la definición de información privilegiada para los instrumentos derivados sobre materias primas, la elaboración de listas de personas con información privilegiada, la notificación de las operaciones efectuadas por directivos y la notificación de las operaciones sospechosas (DOUE L 162 de 30 abril 2004); k) Reglamento (CE) n. ${ }^{\circ}$ 809/2004 de la Comisión de 29 de abril de 2004 relativo a la aplicación de la Directiva 2003/71/CE del Parlamento Europeo y del Consejo en cuanto a la información contenida en los folletos así como el formato, incorporación por referencia, publicación de dichos folletos y difusión de publicidad (DOUE L 149 de 30 abril 2004).

${ }^{26}$ Los más relevantes textos legales comunitarios que armonizan la legislación fiscal nacional de los Estados miembros aplicable a las sociedades en lo relativo a la imposición indirecta son: a) Directiva 90/434/CEE del Consejo, de 23 de julio de 1990, relativa al régimen fiscal común aplicable a las fusiones, escisiones, aportaciones de activos y canjes de acciones realizados entre sociedades de diferentes Estados miembros (DOCE L 225 de 20 agosto 1990); b) Directiva 90/435/CEE del Consejo, de 23 de julio de 1990, relativa al régimen fiscal común aplicable a las sociedades matrices y filiales de Estados miembros diferentes (DOCE L 225 de 20 agosto 1990); c) Directiva 2003/49/CE del Consejo, de 3 de junio 
17. Sin embargo, a pesar de esta labor armonizadora, la regulación legal de las sociedades sigue estando, en una medida muy relevante, en manos de los Estados miembros y de las legislaciones nacionales de cada Estado miembro. La consecuencia de ello es clara. La legislación societaria es distinta de un Estado miembro a otro Estado miembro. Por ello, ad ex., el capital social exigido para constituir una sociedad de capital es menor en el Reino Unido (= sobre unas 100 libras esterlinas para una Private Company Limited by Shares) y mayor en España (= diez millones de la antiguas y recordadas pesetas para una sociedad anónima y 500.000 pesetas para una sociedad de responsabilidad limitada). Resultado: es necesario precisar cuál es la «Ley aplicable» a las sociedades de capital en la UE, porque según sea una u otra la Ley aplicable a la sociedad, el régimen jurídico material de dicha sociedad cambia radicalmente.

\section{Determinación de la Ley aplicable a las sociedades de capital en los Estados miembros}

18. La precisión de la Ley aplicable a las sociedades se lleva a cabo a través de las llamadas «normas de conflicto de Leyes». Pues bien: no existen normas de conflicto «unificadas» en el Derecho comunitario europeo relativas a la Ley aplicable a las sociedades (= como se ha dicho, el art. 48 TCE no es una norma de conflicto de Leyes y no es su misión señalar la Ley apli-

de 2003, relativa a un régimen fiscal común aplicable a los pagos de intereses y cánones efectuados entre sociedades asociadas de diferentes Estados miembros (DOCE L 157 de 26 junio 2003).

${ }^{27}$ Pueden citarse: 1. $^{\circ}$ ) Directiva 2005/56/CE del Parlamento Europeo y del Consejo, de 26 de octubre de 2005, relativa a las fusiones transfronterizas de las sociedades de capital (DOUE L 310 de 25 noviembre 2005); b) Reglamento (CE) n. ${ }^{\circ}$ 2157/2001 del Consejo, de 8 de octubre de 2001, por el que se aprueba el Estatuto de la Sociedad Anónima Europea (SE) (DOCE L 294 de 10 noviembre 2001); c) Directiva 2001/86/CE del Consejo, de 8 de octubre de 2001, por la que se completa el Estatuto de la Sociedad Anónima Europea en lo que respecta a la implicación de los trabajadores (DOCE L 294 de 10 noviembre 2001); d) Reglamento (CE) n. ${ }^{\circ}$ 1435/2003 del Consejo, de 22 de julio de 2003, relativo al Estatuto de la sociedad cooperativa europea (SCE) (DOCE L 207 de 18 agosto 2003); e) Directiva 2003/72/CE del Consejo, de 22 de julio de 2003, por la que se completa el Estatuto de la sociedad cooperativa europea en lo que respecta a la implicación de los trabajadores (DOCE L 207 de 18 agosto 2003); f) Reglamento (CEE) n. ${ }^{\circ}$ 2137/85 del Consejo, de 25 de julio de 1985, relativo a la constitución de una agrupación europea de interés económico (AEIE) (DOCE L 199 de 31 julio 1985). Ni la SE ni la SCE son «sociedades supranacionales». La SE y la SCE son tratadas en cada Estado miembro como una «sociedad constituida con arreglo a la legislación del Estado miembro en el que la sociedad tiene su domicilio social». La SE y la SCE son tipos de sociedades que «coexisten» con los tipos de sociedades de los Estados miembros (STJCE 2 mayo 2006, Parlamento vs. Consejo). 
cable a las sociedades). Ante tal carencia normativa, cada Estado miembro aplica sus propias normas de conflicto (= recogidas en su legislación nacional), para determinar qué concreta Ley estatal es aplicable a las sociedades. Y, como es natural, cada Estado miembro tiene su Historia y tiene su Derecho, de modo que las normas de conflicto en materia societaria son diferentes en cada Estado miembro (P. KInDLER, B. AUDIT ${ }^{28}$ ).

19. Un primer conjunto de Estados miembros siguen la llamada Incorporation Theory o Gründungstheorie $e^{29}$. Según esta teoría, la sociedad se rige por la Ley del Estado con arreglo a cuya legislación se constituye. No importa el lugar de su constitución, ni su sede estatutaria, ni su sede real ni el lugar de su explotación principal (G. BEITZKE ${ }^{30}$ ). Los socios pueden elegir la Ley aplicable a la sociedad: les basta con constituir la sociedad con arreglo a un determinado ordenamiento jurídico. La tesis surgió en Gran Bretaña durante el colonialismo para permitir que las sociedades en manos de los colonos ingleses se rigieran por la Ley inglesa aunque tuvieran su sede estatutaria, dirección o explotación principal en las colonias. Hoy día, esta tesis se sigue en el Reino Unido, Irlanda, Países Bajos, Hungría y, valgan como «ejemplos no comunitarios», Suiza (= vid. art. 154 LDIPr. Suiza 1987), Liechtenstein (= «Ley sobre las personas y las sociedades» PGR de 1997. art. 232), y los

${ }^{28} \mathrm{P}$. KINDLER, «Aspetti essenziali di un futuro regolamento comunitario sulla legge applicabile alle società», RDIPP, 2006-III, pp. 657-674; B. AUDIT, Droit international privé, Economica, París, 4. ${ }^{\text {a }}$ ed., 2006, pp. 868-872.

${ }^{29}$ En torno a esta tesis, vid. A. L. CAlvo CARAVACA, «Las sociedades de capital en el tráfico jurídico internacional», $R G D$, n. 525, 1988, pp. 3679-3701; A. L. CALVo CARAVACA en J. D. GonZÁlez CAmpos y otros, Derecho internacional privado, parte especial, 6. ${ }^{\text {a }}$ ed., Madrid, Eurolex, 1995, pp. 84-89; A. L. Calvo CaravaCA, «Art. 9.11 Cc.», Com.Cc. y

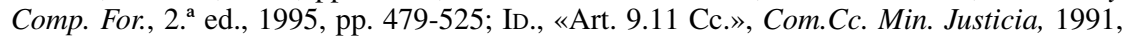
pp. 103-105; F. J. GARCIMARTín AlfÉREZ, Derecho de sociedades y conflictos de leyes: una aproximación contractual, Cuadernos Mercantiles, Ed. de Derecho Reunidas, Madrid, 2002; ID., «Derecho de sociedades: problemas de Ley aplicable», en J. F. DELGADO DE Miguel (CoORd.), Instituciones de Derecho Privado, Tomo VI, Mercantil, Derecho de Sociedades. Parte General, Thomson-Civitas, 2003, pp. 19-152; F. SÁNCHEZ CALERO, «La nacionalidad de la sociedad anónima», Rev. Sociedades, n. 1, 1993, pp. 45-60; C. AzzoLINI, «Problemi relativi alle persone giuridiche nella riforma del diritto internazionale privato», RDIPP, 1993, pp. 893-922; T. BALLARINO, «Les règles de conflit sur les sociétés commerciales à l'épreuve du droit communautaire d'établissement. Remarques sur deux arrêts récents de la Cour de justice des Communautés européennes», RCDIP, 2003-3, pp. 373-402; M. V. BeNEDETTELLI, «La legge regolatrice delle persone giuridiche dopo la riforma del diritto internazionale privato», Rivista delle società, 1997, pp. 39-113; D. DAMASCELLI, I conflitti di legge in materia di società, Cacucci Editore, Bari, 2004; G. GIRELLO, «La legge applicabile alle persone giuridiche nel diritto internazionale privato», DCI, 1996, pp. 285288; S. Rammeloo, Corporations in Private International Law: a European Perspective, Oxford Univ. Press, 2001.

${ }^{30}$ G. BeITZKE, «Les conflits de bis en matiére de fusion de sociétés», RCDIP, 1967, pp. $1-21$. 
Estados Unidos de América (= la regulación de Delaware sobre el particular es mundialmente famosa).

La tesis de la Incorporation presenta ventajas innegables: $\left.1 .^{\circ}\right)$ Beneficia a los socios, que pueden escoger el «Derecho mejor» para organizar su sociedad. No siempre se elegirá el «Derecho menos exigente»: en ocasiones, los socios pueden estimar conveniente elegir un Derecho estatal que sea «exigente» en materia societaria, de modo que dicha elección cumple con una «función de marca» (H. MuIR-WATT ${ }^{31}$ ). Ejemplo: presentarse en el mercado como una sociedad constituida según el Derecho alemán no es lo mismo, como es obvio, que presentarse en el mercado como una sociedad constituida con arreglo al Derecho de Tuvalu. Las sociedades constituidas en países Off-Shore sufren y asumen un «riesgo reputacional» muy elevado (A.-L. Calvo Caravaca / J. Carrascosa González ${ }^{32}$ ). $2 .^{\circ}$ ) Beneficia a los terceros y a la seguridad jurídica: la Ley elegida permanece en el tiempo y los terceros pueden detectar fácilmente cuál es la Lex Societatis. 3. $^{\circ}$ ) Potencia la actividad internacional de la sociedad, porque la sociedad puede desplegar su actividad en varios países y será aceptada como una «sociedad» en tales países sin necesidad de «reconstituirse» con arreglo al Derecho del país donde despliegue sus actividades económicas principales ni con arreglo al país desde el que la sociedad sea dirigida (STJCE 5 noviembre 2002, Überseering FJ 79). La sociedad puede cambiar su «sede real» sin necesidad de cambiar la Ley estatal por la que se rige.

Esta tesis ha sido acusada, sin embargo, de provocar el llamado «síndrome de Delaware», fenómeno al que ciertos autores contemplan con ojos muy despectivos ${ }^{33}$. El fenómeno consiste en lo siguiente: la sociedad se constituye con arreglo a legislaciones societarias permisivas de países con los que no tiene ninguna relación sustancial. Pero la crítica es injusta y poco equilibra-

${ }^{31}$ H. Muir-WaTt, «Nota a STJCE 30 septiembre 2003, Inspire Art», RCDIP, 2004, pp. 173-184.

32 A.-L. Calvo Caravaca / J. Carrascosa González, «Personas jurídicas y sociedades mercantiles», en Derecho Internacional Privado, vol. II, 7. ${ }^{\mathrm{a}}$ ed., Granada, Editorial Comares, 2006, pp. 295-336.

${ }^{33}$ Como hace, por ejemplo, S. SÁnCHez Lorenzo, «El Derecho de establecimiento secundario de las sociedades ficticias en el ámbito comunitario», Libro homenaje al Prof. Sanchez Calero, 2002, pp. 451 y ss.; ID., «El Derecho europeo de sociedades y la sentencia Centros: la relevancia de la sede real en el ámbito comunitario», Anuario Español de Derecho internacional privado, núm. 0, 2000, pp. 115-157; ID., Derecho privado europeo, Granada, Ed. Comares, 2002, pp. 32-33; ID., «Nota a la sentencia TJCE de 5 de noviembre de 2002, As. C-208/00: Überseering», REDI, 2002-2, pp. 927-930; ID., «What Do We Mean when We Say 'Folklore'? Cultural and Axiological Diversities as a Limit for a European Private Law», European Review of Private Law, 2006, 2, pp. 197-219, esp. pp. 205-207. También D. SANCHO VILLA, «La dudosa compatibilidad con el Derecho comunitario de la construcción del Tribunal de Justicia de la Comunidad Europea en la sentencia Centros Ltd», $L a$ Ley, 1999, D-297, pp. 1851-1859. 
da. En efecto, como ha demostrado solvente doctrina (B.H. KoBAYASHI / L.E. RibSTEIN, E.-M. KIENINGER, etc.), las partes eligen libremente la Ley que desean que rija su sociedad y ello no supone ningún fraude a ninguna Ley de ningún país. Donde hay «libre elección de Ley» no puede haber fraude. Además, si los terceros están informados sobre la Ley que rige la sociedad con la que se relacionan, siempre pueden trasladar al precio el riesgo que asumen cuando contratan con sociedades regidas por «Derechos exóticos»o «poco fiables».

20. Un segundo grupo de Estados miembros siguen la llamada «tesis de la sede estatutaria». Según esta tesis, la sociedad se rige por la Ley del país en el que los socios fijan, libremente, el domicilio de la sociedad a efectos civiles. También con esta tesis los particulares pueden elegir la Ley aplicable a la sociedad: les basta con fijar el domicilio en un país, y la Ley de ese país será aplicable a la sociedad. El criterio lo sigue el art. 33 Cc. Portugal, el DIPr. francés y el español (art. 5 LSA y 6 LSRL), con correcciones importantes en estos dos últimos casos. Las ventajas de esta teoría son similares a las que presenta la Incorporation Theory, pues ambas permiten, realmente, que los socios elijan la «Ley aplicable a la sociedad» (A. SANTAMARIA, A. Steiger, S. TAFAni / R. CARUSO, P. KINDLER ${ }^{34}$ ).

21. Un tercer conjunto de Estados miembros acoge la conocida como «teoría de la sede de dirección (Sitztheorie)» (= tesis citada por algunos autores como teoría de la «sede real»). En fin, según esta teoría, la sociedad se rige por la Ley del Estado donde tiene su «sede de dirección» $\mathrm{o}$ «sede de administración», como bien explica la doctrina (U. DrobNIG, B. GrossFelD, M. LuTTER, O. SCHMidt, R. MONACO, S. RindisbaCher, D. ZimmermanN, etc. ${ }^{35}$ ). La

${ }^{34}$ A. SANTAMARIA, «Problemi attinenti al diritto internazionale privato e processuale della società», Studi in memoria di Mario Giuliano, Padua, Cedam, 1989, pp. 805-838; ID., «Sociedad (Diritto internazionale)», EdD, vol. XLII, Milán, Giuffrè, 1990, pp. 883-908; A. STEIGER, Grenzüberschreitende Fusion und Sitzverlegung von Kapitalgesellschaften innerhalb der EU nach spanischem und portugiesischem Recht, 1997; S. TAFANI / R. CARUSO, Il nuovo Diritto europeo delle società di capitali, Roma, 2005, pp. 25-35; P. KINDLER, «Aspetti essenziali di un futuro regolamento comunitario sulla legge applicabile alle società», RDIPP, 2006-III, pp. 657-674.

${ }^{35}$ U. DroBNIG, Kritische Bemerkungen zum Vorentwurf eines EWG-Übereinkommens über die Anerkennung von Gesellschaften. ZHR, 1966-1967, pp. 93-120; B. GROSSFELD, «Die Anerkennung der Rechtsfähigkeit juristicher personen», RabelsZ, 1967, vol. XXXI, pp. 1-50; M. LUTTER (Ed.), Europäische Auslandsgesellschaften in Deutschland: mit Rechtsund Steuerfragen des Wegzugs deutscher Gesellschaften, Köln, O. Schmidt, 2005; R. MoNA$\mathrm{CO}$, «Problèmes du droit international privé des sociétés», Droit international et droit communautaire. (Actes du colloque, París, 5-6 abril 1990), París, 1991, pp. 175-186; S. RinDisBACHER, Anerkennung gesellschaftlicher Gebilde im internationalen Privatrecht, Berna, 1996; D. Zimmermann, Internationales Gesellschaftsrecht, Heidelberg, 1996. 
sociedad se rige, pues, por la Ley del Estado donde radica el lugar desde el que se dirigen las actividades de la persona jurídica (Place of Central Administration). Es un criterio seguido por el art. 40 LDIPr. Rumanía 1992, por el art. 110 Código belga de DIPr. 2004, por el art. 10 Ley Austria DIPr. 1978, y por el DIPr. alemán. Es la tesis germana por excelencia, no hay duda. Fue defendida hace muchos años por el gran jurista E. RABEL. Pero esta tesis presenta varios inconvenientes. Primero: las Big Corporations del siglo XXI son dirigidas desde varios países. Ello provoca el problema del «cúmulo de Leyes aplicables» y el problema de la «indeterminación del lugar de dirección de la sociedad». Segundo: la sede de dirección puede cambiar con extrema facilidad, con lo que surge el problema del «conflicto móvil»: cada vez que la sociedad cambia de lugar de dirección es preciso volver a «constituir la sociedad» con arreglo a un nuevo Derecho estatal, lo que resulta muy costoso, antieconómico y poco realista en una economía cambiante, fluctuante y tendente a la deslocalización como es la economía mundial del siglo XXI.

22. Un cuarto grupo de Estados miembros da cabida en sus normas de conflicto nacionales a la llamada «teoría del centro de explotación». Según esta perspectiva conflictual, la sociedad se rige por la Ley del país donde realiza sus «actividades económicas principales» (lieu d'explotation), como explica la doctrina especialmente en Francia (X. BoucobZA, I. FADLALLAH, J. De Grandcourt, M. G. Van Hecke, M. MenjucQ, Y. Loussouarn / J. D. BREDIN $^{36}$ ). Pero esta tesis plantea dos problemas, análogos a los que muestra la Sitztheorie: «dispersión de lugares de explotación»y «conflicto móvil». El art. 6.2 LSRL y el art. 5.2 LSA abrazan esta teoría en casos concretos y como corrección a la regla general (= que es la teoría de la «sede estatutaria», que a su vez es un modo particular de la Incorporation Theory). Ejemplo: si una sociedad tiene su domicilio en Delaware, USA, pero es realmente una sociedad plena, total e exclusivamente integrada en el mercado español (= con su principal explotación en territorio español), la sociedad quedará obligada a fijar su domicilio estatutario en España y naturalmente, a constituirse con arreglo al Derecho español.

${ }^{36}$ X. BoucobZa, L'acquisition internationale de société, Bib. de droit privé, t. 301, LGDJ, Montchrestien, 1998; I. FAdLALlaH, «Personne morale», E.Dalloz DI, vol. II, 1969, pp. 582-588; J. DE GRANDCOURT, «Societé», E. Dalloz DI, vol. II, 1969, pp. 844-859; M. G. VAN HECKE, «Les sociétés anonymes en droit international privé. Rapport provisoire et projet de resolution», An.IDI, Sesión de Varsovia, 1965, pp. 226-243; M. MENJUCQ, La mobilité des sociétés dans l'espace européen, 1997; ID., Droit internacional et européen des sociétés, 2001, pp. 23-29; Y. LOUSSOUARN, «La condition des personnes morales en droit international privé», RCADI, 1959, vol. 96, pp. 447-552; Y. LOUSSOUARn / J.D. BREDIN, Droit du commerce international, París, Sirey, 1969, pp. 247-530. 


\section{Las normas de conflicto societarias como obstáculo a la libertad de establecimiento de las sociedades en la UE}

\section{El obstáculo: las normas de conflicto de los Estados miembros en mate- ria societaria}

23. Este escenario legal (= diversidad de normas de conflicto entre los Estados miembros + diversidad de normativas materiales de cada Estado miembro relativas a las sociedades), provoca un resultado hoy bien conocido por los expertos societarios: las normas de conflicto de los Estados miembros pueden operar como un auténtico «obstáculo» a la libertad de establecimiento. Una libertad de establecimiento que es, no se olvide, una libertad fundamental garantizada por el Derecho comunitario, una libertad que no puede ser menoscabada por la normativa nacional de los Estados miembros (= primacía de las normas comunitarias relativas a la libertad de establecimiento sobre las normas jurídicas de producción interna de los Estados miembros). Ejemplo: una sociedad limitada constituida en el Reino Unido con arreglo al Derecho inglés desea instalar una sucursal en España. La sociedad desarrolla la mayor parte de sus actividades económicas, o incluso todas sus actividades económicas, en España. Pues resulta que, con arreglo a las normas de conflicto españolas (= art. $9.11 \mathrm{Cc} .+$ art. 6.2 LSRL), esa sociedad es «española», porque su explotación principal está en territorio español. La consecuencia es que dicha sociedad estaría obligada a «re-constituirse» con absoluto respeto al Derecho español. Y mientras no lo haga, la sociedad no puede instalar sucursales en España (= pues o bien se la considera como sociedad «inexistente» o como una sociedad meramente «irregular»). Como es fácil apreciar, con la aplicación a este caso del art. 6.2 LSRL, la sociedad legalmente constituida en el Reino Unido no puede disfrutar de la libertad de establecimiento en la UE. La norma española de conflicto de Leyes (= arts. 9.11 Cc. + art. 52 LSA) opera como un obstáculo, impedimento o barrera a la libertad de establecimiento (= art. 48 TCE).

24. Desde la perspectiva comunitaria, el hecho de que una sociedad válidamente constituida en un Estado miembro y que cumple con los requisitos exigidos por el art. 48 TCE para disfrutar de la libertad de establecimiento sea considerada como «irregular» o «inexistente» en otro Estado miembro, constituye un resultado totalmente inaceptable. Es una sociedad «claudicante» (= existe en un Estado miembro pero bien puede «no existir» en otros Estados miembros).

Naturalmente, la cuestión no tiene nada que ver con el carácter «discriminatorio» o no de la disposición legal que pudiera vulnerar, presuntamente, el derecho a la libre circulación de personas (= el hecho de que las normas de conflicto «nacionales» en materia societaria sean o no sea «discriminatorias» es totalmente irrelevante). Una norma de conflicto del Estado 
miembro de destino puede resultar contraria a la libertad de establecimiento aunque no sea discriminatoria. Así lo ha corroborado el TJCE en contra de la equivocada opinión de los que afirmaban lo contrario ${ }^{37}$.

En efecto, la UE constituye hoy mucho más que un «mercado interior». Es también un «espacio de libertad, de seguridad y de justicia» (art. 61 TCE), un espacio por el que los ciudadanos de la UE, los nacionales de los Estados miembros, tienen derecho a circular libremente (art. 18.1 TCE ${ }^{38}$ ), y en el que las sociedades que cumplen los requisitos del art. $48 \mathrm{TCE}$, tienen derecho a establecerse con total libertad en otros Estados miembros. Y «establecerse libremente» significa establecerse sin «obstáculos jurídicos».

25. Hace ya más de una decena de años que el TJCE afirmó que las «normas de conflicto de Leyes» de los Estados miembros pueden constituir, en ciertos casos, un «perjuicio», «menoscabo», «restricción» u «obstáculo» a la libre circulación de personas y a las demás libertades comunitarias (STJCE 30 marzo 1993, Konstantinidis; STJCE 2 diciembre 1997, Dafeki; STJCE 23 noviembre 2000, Elsen; STJCE 9 marzo 1999, Centros; STJCE 5 noviembre 2002, Überseering, STJCE 30 septiembre 2003, Inspire Art; STJCE 2 octubre 2003, García Avello). La pregunta ahora es la siguiente: ¿por qué las normas de conflicto de Leyes de los Estados miembros pueden suscitar «obstáculos» a las libertades comunitarias? La respuesta es tan sencilla como evidente: porque, como ha escrito con claridad cristalina H. GAUDEMETTALLON $^{39}$, una situación legalmente existente en un Estado miembro (= por ejemplo, una sociedad legalmente constituida en el Reino Unido), creada con arreglo a las normas de conflicto de ese Estado miembro, podría no ser considerada como «existente» y/o «válidamente constituida» en otro Estado miembro (= en España dicha sociedad sería considerada «no existente» o «irregular» si tiene su explotación principal en territorio español). La sociedad «muere» en la frontera entre los Estados miembros. Cuando la situación jurídica (= la sociedad) «cruza la frontera» desde un Estado miembro a otro Estado miembro, la Ley aplicable a tal situación jurídica cambia. Y cambia porque las normas de conflicto del Estado de origen (= con arreglo a las cuales ha sido creada la sociedad) son diferentes de las normas de conflicto del Estado miembro de destino de la sociedad. La «nueva Ley aplicable» a la

${ }^{37}$ Erróneamente, S. SÁNCHEZ LoREnzo, Derecho privado europeo, Granada, Ed. Comares, 2002, pp. 32-33.

${ }^{38}$ Art. 18.1 TCE: «Todo ciudadano de la Unión tendrá derecho a circular y residir libremente en el territorio de los Estados miembros, con sujeción a las limitaciones y condiciones previstas en el presente Tratado y en las disposiciones adoptadas para su aplicación».

${ }^{39}$ H. Gaudemet-Tallon, «De l'utilité d'une unification du droit international privé de la famille dans l'Union Européenne», Estudos Magalhães Collaço, vol. I, Almedina, Portugal, 2002, pp. 159-185. 
sociedad puede considerar que ésta «no existe» o «no es válida»: la sociedad es «claudicante». Y este «cambio de Ley aplicable» puede comportar un obstáculo evidente a la libertad de establecimiento de las sociedades en la UE. En efecto: si una sociedad existe y tiene personalidad jurídica en un Estado miembro pero cuando se intenta instalar una filial o una sucursal en otro Estado miembro ya no se considera una sociedad válidamente constituida, resulta que dicha sociedad «se evapora» en el cruce de frontera. Resultado: las sociedades están, en dicho caso, «desincentivadas» a establecerse en otro Estado miembro porque el Estado miembro de destino le opone obstáculos jurídicos a su libertad de establecimiento. Una sociedad no intentará, o simplemente, no podrá, implantar una sucursal en otro Estado miembro si sabe que en tal Estado miembro dicha sociedad no existe, y con frecuencia, carece de personalidad jurídica aunque la tuviera en el Estado miembro de origen, en el que y con arreglo a cuyas Leyes se constituyó legalmente. Estos inconvenientes son «obstáculos» a la libertad de establecimiento de personas jurídicas, prohibidos por el art. 48 TCE.

26. Numerosas normas de conflicto en materia societaria de los Estados miembros son contrarias al art. 48 TCE. Bastará el examen de dos casos.

a) España. Los arts. 43 y 48 TCE permiten a una sociedad que instale su domicilio estatuario en un Estado miembro y que disponga de su explotación principal y/o sede de dirección en España, sin que se vea obligada, por mandado del art. 5 LSA, a fijar su «domicilio estatutario» en España. El art. 5.2 LSA y 6.2 LSRL son inaplicables en este caso porque tales preceptos suponen, en casos como el señalado, un «obstáculo no justificado» a la libertad de establecimiento de las personas jurídicas en la UE, obstáculo prohibido por el art. 46 TCE.

b) Alemania. El art. 48 TCE permite a una sociedad que instale su domicilio estatutario en un Estado miembro y que disponga de su sede de dirección principal en Alemania, sin que se vea obligada, por mandado del DIPr. alemán, a «reconstituirse» con arreglo a la Ley alemana. La regla alemana de DIPr. que exige que toda sociedad dirigida desde Alemania se rija por el Derecho alemán (Sitztheorie) es un obstáculo incompatible con la libertad de establecimiento. Ejemplo: una sociedad constituida con arreglo al Derecho holandés y con sede social en Holanda pero dirigida desde Alemania debe poder operar e instalar sucursales en Alemania sin ninguna restricción en virtud de la libertad de establecimiento (Sent. Budesgerichtshof 13 marzo 2003).

\section{La labor del TJCE y la trilogía societaria Centros-Überseering-Inspire Art}

27. El TJCE ha confirmado que el art. 48 TCE comporta una total y radical «eurodepuración» de las normas de conflicto societarias de los Estados 
miembros $^{40}$. En efecto, la trilogía societaria del TJCE es demoledora. No deja lugar a dudas. Un recordatorio mínimo de las etapas de la citada trilo-

${ }^{40}$ La bibliografía sobre la jurisprudencia del TJCE relativa a la trilogía societaria formada por las sentencias STJCE 9 marzo 1999, Centros Ltd/Erhvervs- og Selskabsstyrelsen, STJCE 5 noviembre 2002, Überseering, STJCE 30 septiembre 2003, Inspire Art, es, como indica H. MuIR-WATT, una «bibliografía masiva». Un compendio muy completo de dichas referencias bibliográficas puede encontrarse en S. GRUNDMANn, European Company Law, 2004, pp. 839-846. Además, pueden verse: T. BALLARINO, «Les règles de conflit sur les sociétés commerciales à l'épreuve du droit communautaire d'établissement. Remarques sur deux arrêts récents de la Cour de justice des Communautés européennes», RCDIP, 2003-3, pp. 373-402; P. BEHRENS, «Das internationale Gesellschaftsrecht nach dem ÜberseeringUrteil des EuGH und den Schlussanträgen zu Inspire Art», IPrax, 2003, pp. 193-207; S. BRAUN, «Die Europäische Aktiengesellschaft nach 'Inspire Art' bereits ein Auslaufmodell?», Jura, 2005, pp. 150-156; D. DAMASCELLI, I conflitti di legge in materia di società, Cacucci Editore, Bari, 2004; W. F. EBKE, «Centros -Some Realities and Some Mysteries», AJCL, 2001, pp. 623-640; W. F. EBKE, «Überseering: 'Die wahre Liberalität ist Anerkennung'», JZ, 58, 19, 2003, pp. 927-933; F. ESTEBAN DE LA ROSA, «Vía libre a la movilidad de las sociedades en la UE: la STJCE de 30 septiembre 2003 (as. C-167/01), Inspire Art», La Ley, núm. 5924, 31 diciembre 2003; F. J. GarcimarTín AlfÉrez, Derecho de sociedades y conflictos de leyes: una aproximación contractual, Cuadernos Mercantiles, Ed. de Derecho Reunidas, Madrid, 2002; ID., «Derecho de sociedades: problemas de Ley aplicable», en J. F. Delgado de Miguel (Coord.), Instituciones de Derecho Privado, Tomo VI, Mercantil, Derecho de Sociedades. Parte General, Thomson-Civitas, 2003, pp. 19-152; ID., «La Sitztheorie es incompatible con el Tratado CE (algunas cuestiones del Derecho internacional de sociedades iluminadas por la sentencia TJCE de 9 de marzo de 1999)», RDM, 1999, pp. 645 y ss.; ID., «La Sentencia 'Centros': el 'status questionis' un año después», Not.UE, n. ${ }^{\circ}$ 195, 2001, pp. 79-96; ID., «La sentencia Centros del Tribunal de Justicia de las Comunidades Europeas: una visión a través de los comentarios», Revista Electrónica de Estudios Internacionales, 2000, pp. 2 ss.; ID., «La sentencia 'Überseering' y el reconocimiento de sociedades extranjeras: se podrá decir más alto, pero no más claro», RDM, n. 248, 2003, pp. 663682; H. HeIss, «'Überseering': Klarschiff im internationalen Gesellschaftsrecht? Besprechung zu EuGH 5.11.2002 Rs C-208/00 (Überseering)», ZfRV, 44, 3, 2003, pp. 90-97; J.-M. JONET, «Sociétés commerciales. La théorie du siège réel à l'épreuve de la liberté d'établissement», J.Trib.(Brux.). Droit européen, 11, 96, 2003, pp. 33-37; A. JÜTTNER, Gesellschaftsrecht und Niederlassungsfreiheit - nach Centros, Überseering und Inspire Art, Frankfurt am Main, 2005; P. KINDLER, «Auf dem Weg zur Europäischen Briefkastengesellschaft? Die 'Überseering'-Entscheidung des EuGH und das internationale Privatrecht», NJW, 56, 15, 2003, pp. 1073-1079; P. LAGARDE, «Nota a STJCE 5 noviembre 2002, Überseering», RCDIP, 2003, pp. 508-536; S. LeIBLE / J. HofFMANN, «Wie inspiriert ist 'Inspire Art'?», $E Z f W, 2003$, pp. 677-683; A. LÜHN, Rechtsformwahl im nationalen und transationalen Kozern, Verl. Neue Wirtschafts-Briefe, 2004; M. LuTTER (Ed.), Europäische Auslandsgesellschaften in Deutschland: mit Rechts- und Steuerfragen des Wegzugs deutscher Gesellschaften, Köln, O. Schmidt, 2005; ID., «'Überseering' und die Folgen», BB, 58, 1, 2003, pp. 7-10; M. MENJUCQ, «Nota a STJCE 23 septiembre 2003, Inspire Art», JDI Clunet, 2004, pp. 917-929; H. MuIR-WATT, «Nota a STJCE 30 septiembre 2003, Inspire Art», RCDIP, 2004, pp. 173-184; A. PERrone, «Dalla libertà di stabilimento alla competizione fra gli ordinamenti?: riflessioni sul 'caso Centros'», Rivista delle società, 46, 5, settembre-ottobre 2001, pp. 1292-1307; S. Rammeloo, Corporations in Private International Law: a European Perspective, Oxford Univ. Press, 2001; ID., «The long and winding road towards freedom of 
gía jurisprudencial societaria siempre resulta útil para comprender el escenario jurídico actual de las sociedades en la UE.

28. a) STJCE 9 marzo 1999, Centros. Unos esposos daneses constituyeron una sociedad en Inglaterra con arreglo a la Ley inglesa y con sede social en Inglaterra. La sociedad solicitó la apertura de una sucursal en Dinamarca que representaba el $100 \%$ de las actividades de la sociedad, que lógicamente no desarrollaba ninguna actividad comercial en Inglaterra. Las autoridades danesas negaron la posibilidad de abrir la sucursal en Dinamarca, pues estimaron que no se trataba de una «sucursal», sino de un establecimiento principal. Sin embargo, el TJCE entendió que Dinamarca podía adoptar las medidas que estimara convenientes para evitar consecuencias indeseables en el plano fiscal, pero no podía impedir la instalación de la sucursal de la sociedad inglesa en territorio danés. Dinamarca debía admitir, sin paliativos, la

establishment for legal persons in Europe. ECJ case 208/00 Überseering Bv v Nordic Construction Company Baumanagement GmbH (NCC) [2002] not yet reported», M.J., 10, 2, 2003, pp. 169-197; W. H. ROTH, «From Centros to Ueberseering: free movement of companies, private international law, and Community law», ICLQ, 2003, pp. 177-208; A. RousSos, «Realising the free movement of companies», Eur.Bus.L.Rev., 12, n. ${ }^{\circ}$ 1-2, JanuaryFebruary 2001, pp. 7-25; S. SÁNCHEZ LORENZO, «El Derecho de establecimiento secundario de las sociedades ficticias en el ámbito comunitario», Libro homenaje al Prof. Sanchez. Calero, 2002, pp. 451 y ss.; ID., «El Derecho europeo de sociedades y la sentencia Centros: la relevancia de la sede real en el ámbito comunitario», Anuario Español de Derecho internacional privado, núm. 0, 2000, pp. 115-157; E. SCHANZE/A. JÜTTNER, «Die Entscheidung für Pluralität: Kollisionsrecht und Gesellschaftsrecht nach der EuGH-Entscheidung 'Inspire Art'», $A G, 48,12,2003$, pp. 661-671; M. SIEMS, «Convergence, competition, 'Centros' and conflicts of law: European company law in the 21st century», Eur.L.Rev., 27, 1, February 2002, pp. 47-59; G. SIMEN GRAVIR, «Conflict of laws rules for Norwegian companies after the Centros judgement», Eur.Bus.L.Rev., 12, 7-8, July-August 2001, pp. 146-153; G. SPINDLER, «Deutsches Gesellschaftsrecht in der Zange zwischen Inspire Art und Golden Shares?», RIW, 49, 11, 2003, pp. 850-858; G. SPINDLER / O. BERNER, «Der Gläubigerschutz im Gesellschaftsrecht nach Inspire Art», RIW, 50, 1, 2004, pp. 7-16; G. SPINDLER, «El Derecho europeo de sociedades después de Inspire Art y Golden Shares», Revista de Derecho de Sociedades, n. 23, 2004, pp. 65-80; M. P. STRAubE, «Das 'Herkunftslandprinzip' im EUGesellschaftsrecht nach der 'Überseering-Entscheidung'», Österreichische Zeitschrift für Wirtschaftsrecht, 30, 2, 2003, pp. 33-44; V. TRIEBEL/K.A. vON HASE, «Wegzug und grenzüberschreitende Umwandlungen deutscher Gesellschaften nach 'Überseering' und 'Inspire Art'», BB, 58, 46, 2003, pp. 2409-2417; A. TRUNK, «Grenzüberschreitende Insolvenz von Gesellschaften im Verhältnis EG-Scheweiz: Folgerungen aus Centros, Überseering und Inspire Art», SZIER, 2004, pp. 531-557; F. UNZICKER, Niederlassungsfreiheit der Kapitalgesellschaften in der Europäischen Union nach der Centros- und der Überseering-Entscheidung der EuGH, Frankfurt am Main, 2004; M.-PH. WELLER, «Scheinauslandsgesellschaften nach Centros, Überseering und Inspire Art», Iprax, 2003, pp. 207-210; D. ZIMMER, «Nach 'Inspire Art'. Grenzenlose Gestaltugnsfreiheit für deutche Unternehmen?», NJW, 2003, pp. 3585-359; ID., «Wie es Euch gefällt? Offene Fragen nach dem Überseering-Urteil des $\mathrm{EuGH}$ », $B B, 58,1,2003$, pp. 1-7. 
existencia y validez de la sociedad Centros en Dinamarca, por la sencilla razón de que dicha sociedad fue válidamente constituida en el Reino Unido, otro Estado miembro. Y no era para nada relevante que la sociedad desarrollara el $100 \%$ de su actividad en otro Estado miembro, en el Estado miembro en el que tenía su sede estatutaria y con arreglo a cuyas leyes se había constituido (H. MUIR-WATT ${ }^{41}$ ). La sociedad tiene derecho, amparado por la libertad de establecimiento comunitaria, a instalar una sucursal en un Estado miembro a través de la que se lleve a cabo la totalidad de actividades económicas de la sociedad, aunque su sede estatutaria radique en otro Estado miembro distinto. La STJCE 9 marzo 1999, Centros, constituye «una nueva esperanza» para el DIPr. societario europeo: que las normas de conflicto sirvan a la libertad de circulación de las sociedades y para frenar su actividad internacional.

29. b) STJCE 5 noviembre 2002, Überseering. Una sociedad válidamente creada según el Derecho holandés, denominada Überseering, y con domicilio social estatutario en Holanda, trasladó de facto su «sede de dirección» a Alemania, puesto que sus acciones pasaron a manos de accionistas alemanes. Las autoridades alemanas adujeron que la sociedad Überseering debía «reconstituirse» en Alemania. En efecto, según las autoridades alemanas, al tener Überseering ahora su «sede social efectiva» en Alemania, quedaba sujeta al Derecho sustantivo alemán, ya que Alemania sigue el criterio de la Sitztheorie (= criterio según el cual, la sociedad se rige por el Derecho del país en el que tiene su sede social efectiva o de dirección). Por ello, las autoridades alemanas negaron que la sociedad Überseering tuviera personalidad jurídica y capacidad procesal, ya que no estaba constituida con arreglo al Derecho alemán. El TJCE afirmó que la regla alemana de DIPr. (Sitztheorie) suponía un obstáculo a la libertad de establecimiento y era por tanto inaplicable en los casos comunitarios. Por tanto, las autoridades alemanas debían aceptar que Überseering tenía personalidad jurídica y capacidad procesal, aunque no se ajustara a la Ley alemana (= pero sí a la Ley holandesa), ya que negarlo supondría negar la libertad de establecimiento de dicha sociedad en la Comunidad Europea. Bastaba para ello retener que la sociedad Überseering ya había sido válida y legalmente constituida según el DIPr. de otro Estado miembro (= Holanda). El TJCE viene a decir que la sociedad cubierta por el art. $48 \mathrm{TCE}$ tiene derecho, protegido por la libertad de establecimiento comunitaria, a transferir la sede de dirección de un Estado miembro a otro Estado miembro sin perder su personalidad jurídica en virtud de obstáculos jurídicos derivados de las normas de conflicto del Estado miembro

${ }^{41}$ H. Muir-WATt, «Nota a STJCE 30 septiembre 2003, Inspire Art», RCDIP, 2004, pp. 173-184. esp p. 174. 
de destino (H. MuIR-WATT ${ }^{42}$ ). Con la sentencia STJCE 5 noviembre 2002, Überseering, el TJCE contraataca y desautoriza, en especial, a los autores que se habían negado a ver la relevancia fundamental del giro copernicano que suponía la anterior STJCE 9 marzo 1999, Centros.

30. c) STJUE 30 septiembre 2003, Inspire Art. Inspire Art era una sociedad de responsabilidad limitada (private company limited by shares) constituida según las Leyes inglesas y con domicilio social en Inglaterra. La sociedad era dirigida, exclusivamente, desde Holanda por un administrador único. La sociedad disponía de una sucursal en Holanda y todas sus actividades comerciales se desarrollaban en Holanda. Las Leyes holandesas exigían un capital mínimo a las sociedades extranjeras y contenían disposiciones severas sobre la responsabilidad solidaria de los administradores de las sociedades «extranjeras». Las autoridades holandesas insistieron en que la sociedad Inspire Art debía cumplir con tales exigencias de la Ley holandesa. Pero al TJCE no le tembló el pulso y señaló que tales disposiciones eran contrarias a la libertad de establecimiento (art. 48 TCE) y que Inspire Art podía establecerse en el Estado miembro que prefiriera e instalar sucursales en el Estado miembro que prefiriera y ubicar sus actividades comerciales en el Estado miembro donde prefiera: ello no constituye ni abuso ni fraude de Ley, pues es inherente a la libertad de establecimiento, como ha destacado H. ZIEMONS ${ }^{43}$ (vid. también esta expresión literal en la STJCE 30 septiembre 2003, Inspire Art FJ 138). Las normas restrictivas holandesas analizadas no estaban amparadas por «razones imperiosas de interés general». Holanda debía considerar a la sociedad Inspire Art como una sociedad «existente» y «válidamente constituida» también en Holanda y para el ordenamiento jurídico holandés. Explicación: dicha sociedad se había constituido con arreglo a las normas de conflicto de Leyes de otro Estado miembro. El TJCE indica, pues, que una sociedad constituida legalmente en un Estado miembro tiene derecho, amparado por la libertad de establecimiento comunitaria, a ejercer su actividad exclusivamente en otro Estado miembro y a evitar la aplicación de las normas de dicho Estado miembro relativas a la constitución de sociedades (H. MUIR-WATT ${ }^{44}$ ). La STJUE 30 septiembre 2003, Inspire Art, supone el retorno de la libertad de establecimiento y de la «regla de reconocimiento», así como la derrota definitiva de los partidarios de la posible supervivencia de la anacrónica y antieconómica tesis de la sede real ${ }^{45}$.

${ }^{42}$ Ibidem.

${ }^{43}$ H. ZiEMONS, «Freie Bahn für den Umzug von Gesellschaften nach Inspire Art?», ZIP, Heft 42, 17 de octubre de 2003, pp. 1918-1922.

${ }^{44}$ H. Muir-WaTt, op. cit.. pp. 173-184, esp. p. 174.

${ }^{45} \mathrm{La}$ «regla comunitaria de reconocimiento», a la que se alude infra con mayor detalle, nada tiene que ver con el ficticio y falso problema del «reconocimiento de personas jurídicas extranjeras», como se describe con detalle en A. L. CALVO CARAVACA, «Las sociedades de capital en el tráfico jurídico internacional», $R G D, 1988$, pp. 3679-3701; ID,: «Art.9.11 
31. Las enseñanzas básicas (= entre otras muchas «enseñanzas colaterales») que pueden extraerse de la trilogía societaria del TJCE son la siguientes.

a) Una sociedad puede ejercitar toda su actividad en un Estado miembro, siempre que cumpla con las dos exigencias especificadas en el art. 48 TCE. El hecho de que la sociedad no cuente con ningún «vínculo real o sustancial» con el Estado miembro de su constitución es irrelevante. Como indica D. COHEN, la sociedad y los socios tienen derecho a «elegir» unas leyes societarias más laxas en materia de constitución de la sociedad y de responsabilidad de los administradores (STJCE 9 marzo 1999, Centros, FJ 17 y 18, y STJCE 30 septiembre 2003, Inspire Art, FJ 95, 96, 137) ${ }^{46}$. Los socios eligen la Ley de un Estado miembro, simplemente, mediante la instalación nominal de una sede estatutaria en dicho país y mediante la constitución de la sociedad con arreglo a la Ley de ese Estado miembro. Dicha elección, como explica A. KJELlgRen, no constituye ningún fraude de Ley ni ningún abuso del Derecho comunitario y de la libertad de establecimiento ${ }^{47}$. No es tampoco una especie de «U-Turn societario». Es, por el contrario, una libertad protegida nada menos que por los Tratados comunitarios (H. MUIR-WATT ${ }^{48}$ ). Es un derecho subjetivo de las sociedades. Los socios tienen derecho a constituir su sociedad con arreglo al Derecho de un Estado miembro e instalar en dicho Estado miembro su sede estatutaria aunque sus actividades económicas radiquen en otro Estado miembro. Esa decisión de política societaria no puede

Cc.», Com.Cc. y Comp.For., 2. ${ }^{a}$ ed., 1995, pp. 479-525; ID., "Art.9.11 Cc.», Com.Cc. Min.Justicia, 1991, pp. 103-105. Más referencias sobre la cuestión pueden extraerse de numerosos trabajos, como los de C. ANGELICI, Appunti sul riconoscimento delle società constituite all'estero, Milán, 1982; U. DroBNIG, Kritische Bemerkungen zum Vorentwurf eines EWG-Übereinkommens über die Anerkennung von Gesellschaften. ZHR, 1966-1967, pp. 93-120; B. GoLDMAN, «Le droit de sociétés internationales», JDI Clunet, 1963, pp. 320389; ID., «La protection des actionnaries minoritaires des sociétés filiales», Coloque international sur le droit international privé des groupes de sociétés, Ginebra, 1973, pp. 23-41; ID., «The convention between the members of the European Economic Community on the mutual recognition of companies and legal persons», $C M L R$, 1968-69, vol.VI, pp. 104-128; B. GROSSFELD, «Die Anerkennung der Rechtsfähigkeit juristicher personen», RabelsZ, 1967, vol. XXXI, pp. 1-50; P. KAHN: «International companies: A study of companies having a international legal status», JWTL, 1969, pp. 498-521; P. PICONE, «Diritto internazionale privato delle società e riconoscimento di Anstalten e Treuunternehmen nell'ordinamento italiano», Communicazioni e Studi, vol. XV, Milán, Giuffrè, 1978, pp. 83-163; A. SANTA MARIA, «Problemi interpretativi della convenzione CEE sul reciproco riconoscimento delle società e persone giuridiche», Communicazioni e studi, 1970, 291-331; A. Siblini-Vallat, «Les normes matériales internationales d'entreprise», RCDIP, 1988, pp. 653-685.

${ }^{46} \mathrm{D}$. COHEN, «La responsabilité civile des dirigeants sociaux en droit international privé», $R C D I P, 2003$, pp. 585-602.

${ }^{47}$ A. KJELlgren, «On the Border of Abuse: the jurisprudencie of the European Court of Justice on Circumvention, Fraud and Abuses of Community Law», en Services and Free Movement in the UE Law, Oxford Unviersity Press, 2002, pp. 245-249.

${ }^{48}$ H. Muir-WATT, «Nota a STJCE 30 septiembre 2003, Inspire Art», RCDIP, 2004, pp. 173-184, esp. p. 177. 
ser, en ningún caso, contraria a la libertad de establecimiento, porque, precisamente, constituye un derecho derivado de tal libertad. Por eso, la sociedad cubierta por el art. 48 TCE (= que es una sociedad «conectada con la UE») tiene derecho a instalar sucursales en el Estado miembro donde le plazca, a ser considerada y tratada en todo Estado miembro como un ente válidamente constituido con el alcance que la sociedad tiene en el Derecho del Estado miembro con arreglo a cuyo Derecho se constituyó, y tiene derecho también a ejercitar actividades económicas en el Estado miembro que prefiera. Naturalmente, la sociedad puede instalar su sede estatutaria en el Estado miembro donde le plazca y constituirse con arreglo al Derecho de tal Estado miembro (= puede «internacionalizar» la situación jurídica si lo desea), pero eso no supone ningún «fraude por internacionalización ficticia del supuesto» (STJCE 9 marzo 1999, Centros, FJ 16 y 29). En el marco de un mercado comunitario, las sociedades tiene derecho a circular y a instalarse y a operar y a constituirse donde estimen conveniente. El fraude por internacionalización ficticia de un caso interno no puede existir en los límites de la UE ni dentro del mercado único. Es un único mercado en el que la sociedad puede moverse libremente. Por eso, el fraude por internacionalización ficticia del supuesto es imposible ex ipsa natura sua cuando todos los elementos del supuesto radican en la UE.

b) La libertad de establecimiento se opone radicalmente a la aplicación de las normas imperativas de los Estados miembros que impidan a la sociedad aprovecharse del régimen más liberal relativo a la constitución de sociedades y régimen legal interno de las sociedades y previsto en las Leyes de otro Estado miembro. Y ello es así porque para que la libertad de establecimiento tenga un significado verdadero, es preciso aceptar, sin ambages, que los Derechos de los Estados miembros relativos a las condiciones de constitución de las sociedades tienen un grado de equivalencia mutuo. Son, por tanto, «Derechos intercambiables» y los particulares pueden constituir su sociedad en el Estado miembro que tengan por conveniente. Las críticas a este planteamiento, construidas sobre el peligro (= inexistente) de una Race To The Bottom (= cada vez más los Derechos de los Estados miembros tendrían peor calidad en materia societaria), han sido rechazadas del modo más radical por el TJCE. Siempre queda, si existe voluntad política al efecto, la posibilidad de armonizar las reglas societarias de los Estados miembros. Pero no es necesario: todos los Derechos de los Estados miembros en la materia satisfacen las garantías mínimas de una regulación adecuada de las sociedades. Además, si se crea una sana competencia entre los Derechos societarios de los Estados miembros, éstos tenderán a mejorar su reglas para «atraer» sociedades $^{49}$. La competencia entre

\footnotetext{
${ }^{49}$ Una descripción general del fenómeno de la competencia entre ordenamientos estatales se encuentra muy bien expuesta, para los efectos del DIPr., en G. ALPA, Il diritto privato nel prisma della comparazione, Ed. Giappichelli, Turín, 2005, pp. 345-357. Muy profunda,
} 
ordenamientos es, precisamente, «la fuerza motriz del Derecho de sociedades norteamericano», en la ponderada y acertada expresión de H. MuIRWATT $^{50}$.

c) Los Estados miembros conservan, naturalmente, la posibilidad de establecer «obstáculos legales» para la libertad de establecimiento de las llamadas «sociedades buzón» o Pseudo Foreign Corporations (STJCE 30 septiembre 2003, Inspire Art, FJ 102). Sin embargo, tales medidas deben superar el «test de legitimidad comunitario»: deben ser medidas «que se apliquen de manera no discriminatoria, que encuentren justificación en razones imperiosas de interés general, que sean adecuadas para garantizar la realización del objetivo que persiguen y que no vayan más allá de lo necesario para alcanzar dicho objetivo» (STJCE 9 marzo 1999, Centros FJ 34 y STJCE 30 septiembre 2003, Inspire Art FJ 133, que cita jurisprudencia anterior). La protección de los acreedores podría constituir una razón de interés general que suponga un obstáculo para la libertad de establecimiento de las llamadas «sociedades buzón» o Pseudo Foreign Corporations (STJCE 30 septiembre 2003, Inspire Art FJ 102). Pero el TJCE se cuida muy mucho de dejar bien claro que exigir la observancia de las normas societarias del Estado miembro de destino relativas al capital social mínimo y a la responsabilidad de los

igualmente, aunque con ribetes netamente norteamericanos, es la contribución de E. A. O'HARA / L. E. Ribstein, «Conflict Of Laws And Choice Of Law», en B. BoucKAERT AND G. DE GEEST, Encyclopedia of Law and Economics, Universtiy of Ghent and University of Utrecht, 2000, pp. 631-660, esp. p. 643: «Enforcing contractual choice of law is particularly useful in fostering jurisdictional competition for more efficient laws across states. Competition works both by encouraging states to develop new terms to attract new legal business, and by encouraging states to retain legal business by efficiently revising their laws. Jurisdictional competition was first observed with regard to corporations, where a clear choice of law rule, the internal affairs rule in the US, compels application of the law of the state of incorporation. This rule encourages corporations to select the applicable law. Commentators have debated whether this process is a 'race to the bottom' in which the states attract incorporation business by exploiting principal-agent problems resulting from the separation of ownership and controlor a 'race to the top' that is disciplined by efficient capital markets». Resulta de enorme interés, también, por la unión de la competencia entre ordenamientos estatales con la elección del tribunal competente, la exposición de B.H. KOBAYASHI / L.E. RiBSTEIN, «Contract and Jurisdictional Competition', en F. H. BuCKLEY (ed.), Fall and Rise of Freedom of Contract, NC, Duke Univ Press, 1998, e igualmente, pero más radical aún, si cabe, pero con razones muy poderosas, L. E. RIBSTEIN, «Choosing Law by Contract», Journal of Corporation Law, 18, 1993, pp. 245-265, así como E.-M. KIENINGER, Wettbewerb der Privatrechtsordnungen im Europäischen Binnenmarkt, Tubinga, Mohr, 2002, esp. pp. 3339, que hace de la cuestión el eje central del mercado interior. En España, la cuestión ha sido abordada con notable profundidad por M. GARDEÑES SANTIAGO, La aplicación de la regla de reconocimiento mutuo y su incidencia en el comercio de mercancías y servicios en el ámbito comunitario e internacional, Madrid, Ed. Eurolex, 1999, pp. 242-243.

${ }^{50}$ H. Muir-WaTt, «Nota a STJCE 30 septiembre 2003, Inspire Art», RCDIP, 2004, pp. 173-184. esp, p. 181. 
administradores no es una exigencia proporcional ni necesaria (R. CRÔNE ${ }^{51}$ ). Por ello, el respeto de la legislación societaria de los Estados miembros de destino en los aspectos señalados no está cubierto por el Derecho comunitario. Todo lo contrario: tales exigencias están prohibidas por el Derecho comunitario. Son exigencias que revelan un fuerte «autoritarismo» que expulsa de raíz a las sociedades con sede estatutaria en otros Estados miembros, del mercado del Estado miembro de destino. Ello es incompatible con una economía libre de mercado de alcance europeo (H. MUIR-WATT ${ }^{52}$ ). Los acreedores se protegen solos: saben que contratan con una sociedad regulada por un Derecho de otro Estado miembro, siempre que dicha circunstancia conste de modo fehaciente (STJCE 9 marzo 1999, Centros FJ 36).

32. Por cierto, que la solución brindada por el TJCE en la citada trilogía societaria se halla en camino de ser confirmada. Sí, otra vez, para sonrojo de algunos. En efecto, en las Conclusiones del Abogado General Sr. Philippe Léger presentadas el 2 mayo 2006, as. C/196/04, Cadbury Schweppes plc, Cadbury Schweppes Overseas Ltd vs. Commissioners of Inland Revenue, se evalúa la compatibilidad de la legislación del Reino Unido dirigida a combatir la evasión fiscal de las «sociedades extranjeras controladas». El caso surgió a raíz de que la sociedad Cadbury, con sede en Inglaterra, implantara una filial en Irlanda, país con una imposición societaria muy inferior a la del Reino Unido. Implantada la filial en Irlanda, la sociedad imputó rentas por ciertas transacciones a dicha filial. Pero resulta que la filial, realmente, no realizaba tales transacciones. El Abogado General, Sr. Philippe Léger, indica que: «No creo que el hecho de que una sociedad matriz cree una filial en otro Estado miembro con la finalidad reconocida de beneficiarse del régimen fiscal más favorable vigente en éste constituya, en sí mismo, un uso abusivo de la libertad de establecimiento que prive de este modo a la referida sociedad de la posibilidad de invocar los derechos conferidos por los artículos 43 CE y 48 CE. Baso este análisis en el alcance de estas disposiciones, tal como ha sido precisado por la jurisprudencia. El Tribunal de Justicia ha hecho prevalecer la finalidad del derecho de establecimiento conferido por el Tratado. Así, en la sentencia Centros, antes citada, indicó que el derecho a constituir una sociedad de conformidad con la legislación de un Estado miembro y a crear sucursales en otros Estados miembros es inherente al ejercicio, dentro de un mercado único, de la libertad de establecimiento garantizada por el Tratado. El Tribunal de Justicia consideró que el hecho de que un nacional de un Estado miembro que quiere crear una sociedad elija consti-

${ }^{51} \mathrm{R}$. CRÔNE, «La loi applicable aux pouvoirs des dirigeants de sociétés étrangéres», Travaux CF DIPrivé, 1998-2000, pp. 243-259.

${ }^{52}$ H. MuIR-WATT, «Nota a STJCE 30 septiembre 2003, Inspire Art», RCDIP, 2004, pp. 173-184, esp. p. 182. 
tuirla en otro Estado miembro cuyas normas de Derecho de sociedades le parezcan las menos rigurosas y abra sucursales en otros Estados miembros no puede constituir por sí solo un uso abusivo del derecho de establecimiento. Esta solución, que fue adoptada por el Pleno del Tribunal de Justicia, no constituye un hecho aislado. Fue confirmada en la sentencia Inspire Art, en la cual se extendió a la legislación neerlandesa que, en circunstancias comparables a las del asunto Centros, antes citado, no se oponía al registro de una sucursal sino que sometía la creación de dicho establecimiento secundario al cumplimiento de determinados requisitos previstos en el Derecho interno para la constitución de sociedades (...). Una sociedad puede, sin vulnerar el alcance y el espíritu del artículo 43 CE, decidir ejercer sus actividades con carácter secundario en otro Estado miembro para beneficiarse del régimen fiscal más favorable de ese otro Estado por lo que a la tributación de las actividades gravadas en éste se refiere».

33. Pues bien: cuando el «cambio de la Ley aplicable a la sociedad», provocado por las normas de conflicto de Leyes del Estado miembro de destino, suponga un obstáculo a su libertad de establecimiento, varias soluciones son posibles.

3. Primera solución: la técnica de la «regla de reconocimiento comunitario de situaciones jurídicas» (Anerkennungsprinzip)

\section{A) Formulación DE LA REGLA}

34. La primera solución consiste en construir una «regla de reconocimiento comunitario de situaciones jurídicas» (Anerkennungsprinzip). Se trata de un proceso que se desarrolla en dos etapas (Two-Stage Process) (A.-L. Calvo Caravaca / J. Carrascosa González) ${ }^{53}$.

35. Primera etapa: la norma de conflicto societaria del Estado miembro de destino no se aplica en ningún caso, ya que es contraria al Derecho comunitario. En otros términos, las normas de conflicto societarias del Estado miembro de destino deben ser sometidas a un proceso de «eurodepuración» (= precisamente porque su aplicación vulnera el Derecho comunitario). Dicha «eurodepuración» significa que, si la norma de conflicto del Estado miembro de destino perjudica la libertad de establecimiento, dicha norma de conflicto no se aplicará.

53 A.-L. Calvo Caravaca / J. Carrascosa González, Derecho Internacional Privado, vol. I, 7. ${ }^{\text {e }}$ ed., Granada, Editorial Comares, 2006, pp. 30-36. 
36. La «eurodepuración» de las normas de conflicto de Leyes del Estado miembro de destino evita que el «cruce de frontera» comporte «situaciones jurídicas claudicantes» debidas a un «cambio de Ley aplicable». Esta «eurodepuración» actúa como un potente factor de integración europea (= los sistemas de DIPr. ya no «frenan» la libre circulación de personas y factores productivos). Aunque los Derechos Privados sean diferentes de Estado miembro a Estado miembro, el mercado comunitario funciona perfectamente. La diversidad de legislativa no fracciona, por supuesto, el mercado único. Tampoco menoscaba, como es obvio, el funcionamiento del mercado único. Los autores que defienden la «unidad legal» en el mercado único como única salvación para un buen funcionamiento del mercado ignoran gravemen$\mathrm{te}^{54}$. En nombre de un oscuro «totalitarismo legal» de incierto futuro (= que autoproclaman como la «única solución» para un mercado integrado), quieren guillotinar los Derechos nacionales.

37. Cuando se haga valer en España la existencia y validez de una sociedad legalmente constituida con arreglo a las normas de otro Estado miembro, las normas españolas de conflicto de Leyes (= normas de conflicto del Estado miembro de destino) deben ser totalmente «eurocompatibles». Naturalmente, esta eurodepuración debe alcanzar también aquellas otras materias que son todavía «competencia de los Estados miembros», como las sucesiones, las personas jurídicas, el nombre de las personas físicas, los regímenes matrimoniales, la filiación o la capacidad jurídica y de obrar.

38. Segunda etapa: la sociedad «existente» $\mathrm{y}$ «válidamente constituida» en un Estado miembro debe estimarse también «existente» y «válidamente constituida» en los demás Estados miembros. Esta consecuencia, de enorme importancia, es una «derivación necesaria», escribe V. MAGNIER, de las libertades comunitarias, y en concreto, en estos casos, de la libertad de establecimiento $^{55}$. Dicha consecuencia lógica ha sido, además, particularmente desarrollada por el TJCE en el sector de las sociedades mercantiles. Lo que, como indican S. LEIBLE / J. HofFMAnN, no es casualidad ${ }^{56}$. El TJCE, en sus

\footnotetext{
${ }^{54}$ Erróneamente, S. SÁNCHEZ LORENZO, «La unificación del Derecho comercial internacional», en Globalización y comercio internacional, Actas de las XX Jornadas de la Asociación Española de Profesores de Derecho internacional y Relaciones internacionales, Madrid, 2005, pp. 239-265, esp. p. 252: «el hecho de resolver cuestiones transfronterizas a través de la aplicación de un Derecho nacional repugna en sí mismo una visión más cosmopolita o globalizadora acorde con las necesidades palpables en el siglo XXI» (sic).

${ }^{55}$ V. MAGNIER, Rapprochement des droits dans I'Union européenne et viabilité d'un droit commun des sociétés, LGDJ, 1999, pp. 96-110.

${ }^{56}$ S. Leible / J. HofFMANN, «Wie inspiriert ist 'Inspire Art'?», EZfW, 2003, pp. 677-683. Idea que ya se encontraba en estado más embrionario en S. LEIBLE / J. HofFMANN, «Überseering und das (vermeintliche) Ende der Sitztheorie», RIW, 2002, pp. 925 y ss.
} 
STJCE 9 marzo 1999, Centros, STJCE 5 noviembre 2002, Überseering, STJCE 30 septiembre 2003, Inspire Art, ha acogido expresamente esta solución como corolario necesario e inevitable de la libertad de establecimiento. Un brevísimo repaso a ciertos pasajes concretos de los citados pronunciamientos del TJCE ilustrará la posición del TJCE al respecto.

a) La STJCE 9 marzo 1999, Centros FJ 26 in fine, indica que «las disposiciones del Tratado relativas a la libertad de establecimiento tienen como finalidad precisamente permitir a las sociedades constituidas de conformidad con la legislación de un Estado miembro y cuya sede social, administración central o centro de actividad principal se encuentre dentro de la Cотиnidad, ejercer por medio de una agencia, sucursal o filial actividades en otros Estados miembros».

b) La STJCE 5 noviembre 2002, Überseering FJ 93, subraya que ninguna medida del Estado miembro de destino (= incluidas sus normas de conflicto de Leyes, naturalmente) puede tener como resultado «que se niegue la capacidad jurídica y, por tanto, la capacidad procesal a una sociedad válidamente constituida en otro Estado miembro en el que tiene su domicilio social estatutario. En efecto, una medida de este tipo equivale a la negación misma de la libertad de establecimiento reconocida a las sociedades por los artículos 43 CE y 48 CE».

c) La STJCE 5 noviembre 2002, Überseering FJ 95, vuelve a expresar esta idea con una contundencia inmisericorde: «[c]uando una sociedad constituida con arreglo a la legislación de un Estado miembro en cuyo territorio se encuentra su domicilio social estatutario ejerce su libertad de establecimiento en otro Estado miembro, los artículos 43 CE y 48 CE obligan a este último a reconocer la capacidad jurídica y, por tanto, la capacidad procesal que dicha sociedad tiene de conformidad con el Derecho de su Estado de constitución», lo que se reitera en los FJ 57, 58 y 59: «De lo anterior se deduce directamente que dichas sociedades tienen derecho a ejercer su actividad en otro Estado miembro, sirviendo la localización de su domicilio social estatutario, su administración central o su centro de actividad principal para determinar, a semejanza de la nacionalidad de las personas físicas, su sujeción al ordenamiento jurídico de un Estado miembro. El Tribunal de Justicia basó en estas premisas su razonamiento en el asunto Centros, antes citado (apartados 19 y 20). Pues bien, el ejercicio de la libertad de establecimiento implica necesariamente el reconocimiento de dichas sociedades por todo Estado miembro en el que deseen establecerse» y en el FJ 81, pues «[e]s más, su propia existencia [de la sociedad Überseering] es consustancial a su condición de sociedad neerlandesa en la medida en que, como se ha recordado, una sociedad sólo tiene existencia a través de la legislación nacional que determina su constitución y funcionamiento (véase, en este sentido, la sentencia Daily Mail and General Trust, antes citada, apartado 19). La exigencia de reconstitución de la misma sociedad en Alemania equivale, en consecuencia, a la negación misma de la libertad de establecimiento». 
39. Por tanto, para que la libertad de establecimiento de las sociedades sea una realidad en la UE, es absolutamente necesario que las normas de DIPr. del Estado miembro de destino «respeten» la constitución (= válida) de la sociedad en otro Estado miembro. $\mathrm{O}$ en otros términos: la libertad de establecimiento exige la «continuidad espacial» en toda la UE de las sociedades legalmente constituidas en un Estado miembro. Digan lo que digan, por supuesto, las normas de conflicto nacionales de los Estados miembros (= que resultan, en la práctica, totalmente inaplicables). Todavía más: como indica D. ZIMMER, el TJCE ha optado por otorgar un «efecto conflictual» a la libertad de establecimiento ${ }^{57}$. O como expresa F. J. GARCIMARTín AlfÉreZ, «el TJCE no se limita a un control del resultado material sino que entra en el proceso conflictual y su compatibilidad con el Tratado» ${ }^{58}$. De la libertad de establecimiento deriva una «regla de DIPr.» (= que no es, técnicamente hablando, una regla de «conflicto de Leyes»): las sociedades se rigen por la Ley que se aplicó en el Estado miembro de origen a su constitución. Sorprende de manera muy llamativa que ciertos autores no realicen ni siquiera una alusión pasajera a esta solución (Anerkennungsprinzip) ${ }^{59}$, tanto por haber sido acogida por el TJCE, como por su enorme importancia teórico-práctica.

${ }^{57}$ D. ZIMMER, «Nach 'Inspire Art'. Grenzenlose Gestaltugnsfreiheit für deutche Unternehmen?», NJW, 2003, pp. 3585-3590; ID., «Wie es Euch gefällt? Offene Fragen nach dem Überseering-Urteil des EuGH», BB, 58, 1, 2003, pp. 1-7.

${ }^{58}$ F. J. GARCIMARTín AlFÉREZ, «La sentencia 'UUberseering' y el reconocimiento de sociedades extranjeras: se podrá decir más alto, pero no más claro», $R D M$, n. 248, 2003, pp. 663682. Reflexiones similares, con matices muy acertados, pueden encontrarse en otros trabajos del mismo autor. Ad ex., vid. F. J. Garcimartín AlfÉREZ, Derecho de sociedades y conflictos de leyes: una aproximación contractual, Cuadernos Mercantiles, Ed. de Derecho Reunidas, Madrid, 2002; ID., «Derecho de sociedades: problemas de Ley aplicable», en J. F. Delgado de Miguel (Coord.), Instituciones de Derecho Privado, Tomo VI, Mercantil, Derecho de Sociedades. Parte General, Thomson-Civitas, 2003, pp. 19-152; ID., «La Sitztheorie es incompatible con el Tratado CE (algunas cuestiones del Derecho internacional de sociedades iluminadas por la sentencia TJCE de 9 de marzo de 1999)», RDM, 1999, pp. 645 y ss.; ID., «La Sentencia 'Centros': el 'status questionis' un año después», Not.UE, n. ${ }^{\circ} 195$, 2001, pp. 79-96; ID., «La sentencia Centros del Tribunal de Justicia de las Comunidades Europeas: una visión a través de los comentarios», Revista Electrónica de Estudios Internacionales, 2000, pp. 2 ss.

${ }^{59}$ Ignora completamente la regla comunitaria del reconocimiento, por ejemplo, S. SÁNCHEz LoRENzo, Derecho privado europeo, Granada, Ed. Comares, 2002, pp. 137-140; ID., «What Do We Mean when We Say 'Folklore'? Cultural and Axiological Diversities as a Limit for a European Private Law», European Review of Private Law, 2006, 2, pp. 197-219, esp. pp. 205-207, que ofrece un tratamiento descriptivo y superficial, y en suma, equivocado, del «principio de origen» en Derecho comunitario. También ignora plenamente esta nueva regla y este nuevo método, D. SANCHO VILLA, La transferencia internacional de la sede social en el espacio europeo, Eurolex, Madrid, 2001; ID., «El traslado del domicilio social a España en el Registro Mercantil», AEDIPr, 2000, pp. 465 y ss.; Id., «La dudosa compatibilidad con el Derecho comunitario de la construcción del Tribunal de Justicia de la Comunidad Europea en la sentencia Centros Ltd», La Ley, 1999, pp. 1851-1859. 
Solución que abre perspectivas muy interesantes para la construcción europea, como ha sido subrayado por la mejor doctrina (P. LAGARDE, E. JAYME / CH. KöHLER, H. Muir-Watt, H. Gaudemet-TaLlON $\left.{ }^{60}\right)$.

40. Ejemplo: una sociedad anónima constituida legalmente en Irlanda desea instalar una sucursal en España. La totalidad de la explotación económica de la sociedad se halla en España. El texto vigente del art. 5.2 LSA exige que dicha sociedad, precisamente por disponer de su «entera explotación» (= «principal explotación», dice el precepto legal), en España, se debe constituir con arreglo a la Ley española. Pues bien: en este supuesto, el art. 5.2 LSA es contrario a la libertad de establecimiento porque «obliga» a una sociedad legalmente constituida en Irlanda a «re-constituirse» en España y no la considera «válidamente constituida en España» a todos los efectos legales. La sociedad «legalmente constituida en Irlanda» no sobrevive al «paso de frontera» (STJCE 5 noviembre 2002, Überseering, FJ 79), porque el art. 5.2 LSA se encarga de exterminar tal sociedad en España. Por tanto, no cabe duda de que el art. 5.2 LSA es inaplicable a este caso (= debe ser sometido a una radical «eurodepuración»). Y para acreditar si la sociedad irlandesa se ha constituido legalmente, las autoridades españolas deberían controlar dicho extremo con arreglo a la Ley estatal que aplicaron las autoridades irlandesas para aceptar la constitución de la sociedad. Las autoridades españolas aplicarán las normas de conflicto irlandesas (= y no las normas de conflicto españolas: art. 9.11 Cc. + art. 5 LSA), y en consecuencia, aplicarán también la Ley a la que conducen las normas de conflicto irlandesas.

\section{B) BASE TEÓRICA Y TÉCNICA DE LA REGLA}

41. Interesa ahora destacar los perfiles teóricos y técnicos que sustentan la solución consistente en esta «regla de reconocimiento comunitario de situaciones jurídicas» (Anerkennungsprinzip).

\footnotetext{
${ }^{60}$ P. LAGARDE, «Développements futurs du droit international privé dans une Europe en voie d'unification: quelques conjectures», RabelsZ, 2004, pp. 225-243, esp. p. 227; ID. «Nota a STJCE 5 noviembre 2002, Überseering», RCDIP, 2003, pp. 508-536; E. JAYME / СH. KÖHLER, «Europäisches Kollisionsrecht 2001: Anerkennungsprinzip statt IPR?», IPrax, 2001, pp. 501-512; E. JAYME, «Il diritto internazionale privato nel sistema comunitario e i suoi recenti sviluppi normativi nei rapporti con Stati terzi», RDIPP, 2006, pp. 353-360, esp. p. 360; H. MuIR-WATT, «Nota a STJCE 30 septiembre 2003, Inspire Art», RCDIP, 2004, pp. 173-184; H. GAUDEMET-TALLON, «De l'utilité d'une unification du droit international privé de la famille dans l'Union Européenne», Estudos Magalhães Collaço, vol. I, Almedina, Portugal, 2002, pp. 159-185.
} 
42. La «regla de reconocimiento comunitario de situaciones jurídicas» (Anerkennungsprinzip) es, como subraya D. HENRICH, un método totalmente diferente al clásico método decimonónico made by Savigny ${ }^{61}$. El método savignyano consiste, como es bien sabido, en remitir, para la regulación de una situación privada «internacional», a un concreto Derecho estatal. Tal Derecho estatal proporcionará la regulación material de dicha situación privada internacional. En términos generales (= pues matices muy importantes, como los sugeridos por P. LAGARDE, en su brillante curso de 1986, son posibles $^{62}$ ), la norma de conflicto clásica diseñada por F.K. VON SAVIGNY remite la regulación material de una situación privada internacional al Derecho del país con el cual la situación presenta el vínculo más estrecho. El DIPr. comunitario que utiliza el nuevo método de la «regla de reconocimiento comunitario de situaciones jurídicas» (Anerkennungsprinzip) es «un instrumento para la integración europea» (D. COESTER-WALTJEN) y como tal debe ser contemplado y analizado ${ }^{63}$. Nos encontramos, escribe E. JAYME, "ante el amanecer de un nuevo, de un diferente Derecho internacional privado [y] todos los que hemos crecido con el Derecho internacional privado de Savigny y de Mancini debemos decir adiós a estos métodos clásicos ${ }^{64}$. El principio del reconocimiento comunitario de situaciones jurídicas forma parte del mismo Derecho comunitario. En el marco de dicho ordenamiento, este «nuevo método» no es tan nuevo. Recuerda M. BOGER que la línea de jurisprudencia del TJCE que se inició con Cassis de Dijon ha triunfado porque contiene una fórmula de éxito basada en un razonamiento económico sencillo: el «principio de origen» ahorra costes porque evita el fraccionamiento del mercado único europeo en pequeños cotos sujetos a las legislaciones de cada Estado miembro ${ }^{65}$. Sin exterminar los Derechos nacionales, permite que las empresas sometan sus actividades al Derecho de un solo Estado miembro. Ello es válido tanto para las actividades de fabricación de productos (P. OLIVER /

${ }^{61}$ D. HENRICH, «Anerkenung statt IPR. Eine Grundsatzfrage», IPRax, 2005, pp. 422-429, cuyas tesis comparte E. JAYME, «Il diritto internazionale privato nel sistema comunitario e $\mathrm{i}$ suoi recenti sviluppi normativi nei rapporti con Stati terzi», RDIPP, 2006, pp. 353-360, esp. p. 355.

${ }^{62}$ P. LAGARDE, «Le principe de proximité dans le droit international privé contemporain», RCADI, 1986, vol. 196, pp. 9-238, esp. pp. 44-49.

63 D. Coester-Waltjen, «Das Anerkennungsprinzip im Dornröschenshalf», en Festschrift Erik Jayme, vol. I, Munich, 2004, pp. 121-132.

${ }^{64} \mathrm{Al}$ que sigue E. JAYME, «Il diritto internazionale privato nel sistema comunitario e $\mathrm{i}$ suoi recenti sviluppi normativi nei rapporti con Stati terzi», RDIPP, 2006, pp. 353-360, esp. p. 356.

${ }^{65}$ M. Boger, Die Anwendbarkeit der Cassis-Formel auf Ungleichbehandlungen im Rahmen der Grundfreiheiten: eine Untersuchung auf Grundlage der Rechtsprechung des EuGH unter besonderer Berücksichtigung des Begriffs der mittelbaren Diskriminierung, Berlín, 2004, esp. pp. 43-44. 
M.A. JARVIS ${ }^{66}$ ), como para las actividades de prestación de servicios (L. Woods ${ }^{67}$ ). Esta jurisprudencia ha sido, sin duda, la plataforma de lanzamiento idónea para forjar una regla de reconocimiento comunitaria que pueda aplicarse en relación con las situaciones de Derecho privado legalmente creadas en un Estado miembro y que se desean hacer valer (= «exportar») en otros Estados miembros. Como sucede en relación con las sociedades legalmente creadas en un Estado miembro que desean instalar sucursales o filiales en otro Estado miembro (N.N. SHUIBHNE ${ }^{68}$ ). El nuevo método de la regla de reconocimiento invade todo el tableau communautaire de los primeros años del siglo XXI, como expresaron con sagacidad, ya hace años, E. JAYME / CH. KöHLER ${ }^{69}$. Es una regla de DIPr. que se impone, pues, a los Estados miembros y a sus sistemas «nacionales» de DIPr.

43. Como explica P. LAGARDE, este método no es difícil de comprender. En presencia de una situación privada internacional (= ejemplo: una sociedad constituida en un Estado miembro que desea instalar una sucursal en otro Estado miembro), la cuestión jurídica no se resuelve mediante la simple determinación de la «Ley aplicable» a dicha situación (= Ley aplicable a la sociedad constituida en otro Estado miembro para acreditar que se trata, realmente, de una sociedad válidamente constituida). El enfoque es radicalmente diferente. Nada de aplicar las normas de conflicto de Leyes del Estado miembro de destino de la sociedad (= que es el enfoque tradicional construido sobre el «principio de exclusividad del DIPr.» ${ }^{70}$ ). Ahora la perspectiva es distinta. En efecto, para que una situación legalmente creada en un Estado miembro (= la sociedad de capital legalmente constituida en un Estado miembro), produzca efectos legales en otro Estado miembro, las normas de conflicto del Estado miembro de destino no deben ser aplicadas (= en el caso

${ }^{66}$ P. Oliver / M. A. JARVIS, Free movement of goods in the European Community under articles 28 to 30 of the EC treaty, $4 .^{\text {a }}$ ed., Londres, 2003, esp. p. 99.

${ }^{67}$ L. Woods, Free movement of goods and services within the European community, Aldershot, 2004, esp. pp. 34-39.

${ }^{68}$ N. N. ShuiBhnE, «The free movement of goods and Article 28 EC: an evolving framework», Eur.L.Rev., 27, 4, 2002, pp. 408-425.

${ }^{69}$ E. JAYME / CH. KöHLER, «Europäisches Kollisionsrecht 2001: Anerkennungsprinzip statt IPR?», IPrax, 2001, pp. 501-512.

${ }^{70}$ Como se explica en A.-L. Calvo Caravaca / J. Carrascosa González, Derecho

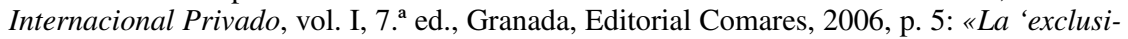
vidad del DIPr.' significa que, para resolver los problemas jurídicos que plantean las situaciones privadas internacionales, los tribunales y autoridades españolas aplicarán, exclusivamente, el DIPr. español, y no el DIPr. de otros países (SAP Barcelona 3 marzo 2004). Cuando debe fijarse el 'régimen jurídico de fondo' de una situación privada internacional, las autoridades y tribunales españoles aplican, por tanto, las 'normas españolas de DIPr.'. Tales 'normas españolas de DIPr.' indicarán el 'Derecho aplicable' a la situación privada internacional, que puede ser bien el Derecho español o bien un Derecho extranjero». 
de que tales normas provocaran una lesión de la libertad de establecimiento $^{71}$. Ello evita situaciones jurídicas claudicantes (= situation boiteuse). En efecto, ello impide que una sociedad «exista» en un Estado miembro, pero no en otro Estado miembro. Por tanto, no deben ser aplicadas las normas de conflicto del Estado miembro de destino cuando conduzcan a ese pernicioso resultado. En otras palabras: el «DIPr. del foro» (= las normas de conflicto del Derecho del país al que pertenece la autoridad que «valora» la idoneidad jurídica o legalidad de la sociedad creada en otro Estado miembro) no se aplica. En el fondo, el problema de la Ley aplicable (= ese «cómo encontrar la mejor conexión» para las situaciones jurídicas internacionales), un problema que ha preocupado profundamente a la doctrina internacionalprivatista desde hace centenares de años, es ahora un «problema menor». No importa qué Ley estatal se aplicó en otro Estado miembro para crear la situación jurídica (= la sociedad de capital). Eso es indiferente en el marco del método Anerkennungsprinzip, como indican E. JAYME / CH. KöHLER ${ }^{72}$. Lo relevante es que la sociedad de capital haya sido «legalmente creada en un Estado miembro» (= con arreglo a las normas de conflicto de Leyes del Estado miembro de origen de la sociedad). Por ello, puede afirmarse que este «nuevo método» supone un cierto retorno al «unilateralismo» $\left(\mathrm{P} . \mathrm{LAGARDE}^{73}\right)$. En efecto: la situación jurídica (= la sociedad de capital) será considerada como válidamente constituida y plenamente eficaz a efectos jurídicos en un Estado miembro siempre que haya sido constituida legalmente en otro Estado miembro con arreglo a las normas de conflicto de Leyes de ese último Estado miembro. Cada Estado miembro «crea» las sociedades de capital con arreglo a sus normas de conflicto de Leyes y los demás Estados miembros deben «reconocer» tales sociedades de capital como sociedades legalmente existentes y válidamente constituidas en toda la UE. Con otras palabras, puede afirmarse que este unilateralismo es el resultado de un «conflicto de sistemas» resuelto en favor del sistema de DIPr. (= de las normas de conflicto de Leyes) del Estado miembro de constitución de la sociedad de capital. El «conflicto de sistemas» es una técnica de DIPr. con raíces muy profundas en

${ }^{71}$ P. Lagarde, «Conflits de lois (Principes généraux)», Répertoire Dalloz Droit International, enero 2006, pp. 1-30, esp. p. 28 ; ID., «Développements futurs du droit international privé dans une Europe en voie d'unification: quelques conjectures», RabelsZ, 2004, pp. $225-$ 243.

72 E. JAYME / CH. KÖHLER, «Europäisches Kollisionsrecht 2001: Anerkennungsprinzip statt IPR?», IPrax, 2001, pp. 501-512, esp. p. 502, que subrayan que igualmente es indiferente, salvo vulneración del orden público internacional, la Ley aplicada por el juez de origen en el marco de un sistema moderno de reconocimiento de decisiones judiciales, como el recogido en el Reglamento 44/2001 de 22 diciembre 2000.

${ }^{73}$ P. LAGARDE, «Conflits de lois (Principes généraux)», Répertoire Dalloz Droit International, enero 2006, pp. 1-30, esp. p. 28 ; ID., «Développements futurs du droit international privé dans une Europe en voie d'unification: quelques conjectures», RabelsZ, 2004, pp. 225243. 


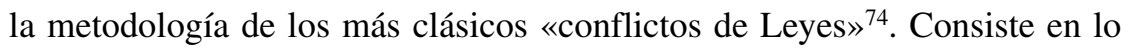
siguiente: en ciertos supuestos, debe aplicarse el sistema de DIPr. (= las «normas de conflicto de Leyes») del Estado miembro cuyas autoridades intervinieron en la creación de una situación jurídica o en el que se creó dicha situación jurídica. En tales casos, las normas de conflicto del Estado miembro de destino de la sociedad son inaplicables. Es cierto que el problema del conflicto de Leyes (= determinar la Ley aplicable a una sociedad en casos internacionales) siempre pervive. Es una «question irréductible», escribe P. LAGARDE ${ }^{75}$. Y es una cuestión irreductible porque, cuando la sociedad se constituye, es preciso aplicar, en todo caso, una Ley estatal (= pues una sociedad de capital sólo existe si una Ley estatal así lo determina) que resulta aplicable a la creación y constitución de la sociedad. Dicha Ley estatal se determina con arreglo a las normas de conflicto del Estado miembro «de origen» de la sociedad (= Estado miembro con arreglo a cuyas normas de DIPr. se creó la sociedad). Los conflictualistas podemos respirar tranquilos porque este nuevo método de la «regla del reconocimiento» convive con el tradicional método de los «conflictos de Leyes», con la «parte noble» del Derecho internacional privado. Hasta aquí el basamento teórico, sencillo, como es fácil apreciar, del «nuevo método».

${ }^{74}$ A.-L. Calvo Caravaca / J. Carrascosa González, Derecho Internacional Privado, vol. I, 7. ${ }^{\text {a }}$ ed., Granada, Editorial Comares, 2006, pp. 5-6: «En ciertos casos, la regla general de la exclusividad del DIPr. experimenta excepciones concretas, que permiten al juez. español aplicar normas extranjeras de DIPr. Se dice entonces que se produce un 'conflicto de sistemas' porque el tribunal español se plantea esta cuestión: ¿qué 'sistema de DIPr.' debe aplicarse al caso, el 'sistema español' de DIPr. o un 'sistema extranjero' de DIPr.? La razón de ser de los 'conflictos de sistemas' es sencilla: se trata de hacer aplicable el sistema de DIPr. del país 'más conectado con el supuesto concreto' para reforzar la seguridad jurídica en el contexto internacional y evitar que el DIPr. del país cuyos tribunales conocen del asunto se aplique, de modo imprevisible, a 'supuestos no conectados estrechamente' con tal país». Sobre los conflictos de sistemas, vid. H. BATIFFol / P. LAGARDE, Droit international privé, t. I, 8. a ed., LGDJ, París, 1993, pp. 473-474 y 491-492; A. BuCHER, «Über die räumlichen Grenzen der Kollisionsnormen», Festschrift Frank Vischer, Zürich, 1983, pp. 93 105; PH. FRANCESCAKIS, La théorie du renvoi et les conflits de systèmes en droit international privé, París, 1958, pp. 189-203; ID., «Nota sent. Rabat 24 octubre 1950», RCDIP, 1952, p. 89; ID. «Nota sent. París 7 julio 1954», RCDIP, 1954, pp. 582 ss.; ID., «Conflits de lois (Principes généraux)», E.Dalloz DI, vol. I, París, 1968, pp. 470-497. En lengua castellana, la mejor y más completa exposición es la de E. Castellanos Ruiz, Unidad vs. pluralidad legal de la sucesión internacional, Comares, Granada, 2001.

${ }^{75}$ P. LAGARDE, «Développements futurs du droit international privé dans une Europe en voie d'unification: quelques conjectures», RabelsZ, 2004, pp. 225-243, esp. p. 229: «La question des conflits de lois este irréductible. Lors de la création de situations juridiques hétérogènes, tant que subsisteront des divergences dans les législations en présence, toute autorité judiciaire ou administrative, ou même des particuliers à l'occasion d'un contrat, par exemple, devront toujours, au moment de la prise de décision, déterminer le droit applicable». 
44. Más complejo es el «basamento técnico» de este nuevo método. Y es más complejo porque en Derecho internacional privado nada es más cierto que nihil novum sub sole. En Derecho internacional privado, todo se ha escrito, todo se ha dicho, todo ha sido ya inventado de una u otra forma. En efecto: este nuevo método puede ser explicado y comprendido a través de numerosas técnicas desarrolladas en la Ciencia de los Conflictos de Leyes desde hace muchos años. Así es: la justificación teórica del «abandono» de las normas de conflicto del Estado miembro de destino en favor de las normas de conflicto del Estado miembro de origen se ha justificado, en el DIPr. clásico, con varios expedientes. Los más importantes son los que siguen.

45. a) Tesis del «doble reenvío». La autoridad que conoce del asunto debe operar exactamente como lo haría la autoridad del país a cuya Ley remiten las normas de DIPr. del país cuyos tribunales conocen del asunto, por lo que aplicará el «DIPr. extranjero» (= normas extranjeras de conflicto de Leyes). De ese modo se evitan situaciones claudicantes y se respeta la «soberanía extranjera» del país cuyas autoridades «crearon» una situación jurídica. Como explica J. D. FALCONBRIDGE, el llamado «doble reenvío» (Foreign Court Theory / Total Renvoi / Doble renvoi) es una construcción propia del DIPr. anglosajón ${ }^{76}$. Está inspirada en las ideas de DiCEY. Según esta teoría, el juez o autoridad que conoce del asunto debe aplicar el Derecho material que se supone que aplicarían los tribunales o autoridades del país cuya Ley es declarada aplicable por su norma de conflicto. Es decir, la autoridad que conoce (ahora) del asunto debe decidir del mismo modo como lo haría una autoridad juez del país cuya Ley es declarada aplicable por la norma de conflicto del Estado cuya autoridad está conociendo ahora del asunto. En realidad, el doble reenvío anglosajón es un remedio a la amplitud de los criterios de competencia internacional de las autoridades de un Estado. Por eso los jueces anglosajones fallan como lo haría una autoridad extranjera (= que estaría «mejor situada» para conocer del caso y de hecho, estuvo «mejor situada» para «crear» la situación jurídica $)^{77}$.

46. b) Tesis de las «situaciones creadas y agotadas en el extranjero». A tenor de esta célebre tesis, creada y divulgada por PH. FRANCESCAKIS y refle-

\footnotetext{
${ }^{76}$ J. D. FALCONBRIDGE, «Le renvoi et la loi du domicile», RCDIP, 1948, pp. 4571; ID., «Renvoi, Characterisation and Acquired Rights», Canadian Bar Review, 1939, vol. 17, pp. 379-ss.

77 A.-L. Calvo Caravaca / J. Carrascosa González, Derecho Internacional Privado, vol. I, 7. ${ }^{a}$ ed., Granada, Editorial Comares, 2006, pp. 236-247. La SAP Badajoz 11 julio 1995 ilustra con acierto la figura del doble reenvio en DIPr. inglés, que se ha visto aplicada, entre otros, en los casos Collier vs. Rivaz (1841), In re Annesley (1926), In re Ross (1930), In Re Askew (1930), In re O'Keefe (1944), In re Duke of Wellington (1947), In re C.W.Addams (31 julio 1985), fallado por la High Court Of Justice (Chancery Division).
} 
jada inmejorablemente por la Sent. CA París 19 marzo 1965, Banque otto$\operatorname{mane}^{78}$, la validez de las situaciones jurídicas conectadas estrechamente con países extranjeros y verificadas en el pasado debe regularse con arreglo al DIPr. de dicho país ${ }^{79}$. No debe aplicarse el DIPr. del país cuyas autoridades están, ahora, valorando la regularidad jurídica del supuesto. De ese modo, se reafirma la seguridad jurídica de los particulares implicados y la circulación internacional de situaciones jurídicas creadas legalmente. En efecto, si la situación jurídica resulta «muy alejada en el espacio y en el tiempo» del país cuyas autoridades conocen del asunto, no deben entonces aplicarse las normas de conflicto del Estado miembro de destino, sino las normas de conflicto del Estado miembro de origen de la situación jurídica (= normas de conflicto del Estado miembro donde, en un momento anterior, y en un Estado diferente, se creó la sociedad). La teoría fue y es empleada también como una corrección a los devastadores efectos del orden público internacional en el marco del DIPr. (= para evitar una extensión imperialista del orden público internacional contra la aplicación de Leyes extranjeras que, realmente, no producen efectos jurídicos en la esfera jurídica del país cuyas autoridades conocen del asunto).

Una variante de esta tesis ha sido defendida por M.-N. JOBARD-BACHELLIER $^{80}$ (= tesis de los «supuestos espacialmente alejados»). Según esta variante de la tesis básica anterior, los casos cuyos elementos están estrechamente conectados con un país distinto al país cuyas autoridades conocen del asunto, deben regirse por las normas de conflicto del país con el que presentan una «estrecha conexión» y no necesariamente por las normas de conflicto del Estado del foro (= Estado miembro de destino). La novedad radica en que el enfoque deriva del «principio de la apariencia»: los particulares confían en la aplicación de las Leyes a las que remiten las normas de conflicto del país con el que la situación «aparece más estrechamente conectada».

${ }^{78}$ Imprescindible es la lectura de la clásica contribución de PH. FRANCESCAKIs, La théorie du renvoi et les conflits de systemes en droit international privé, París, Sirey, 1958, esp. pp. 55-59 y 189-203. Vid., igualmente, Рн. FRANCESCAKIS, «Droit international privé», E. Dalloz DI, vol. I, 1968, pp. 671-674; ID., «Droit international privé comparé», E.Dalloz DI, vol. I, 1968, pp. 674-688; ID., «Conflits de lois (Principes généraux)», E. Dalloz DI, vol. I, París, 1968, pp. 370-497; ID., «Nota sent. Rabat 24 octubre 1950», RCDIP, 1952, p. 89; ID. «Nota sent. París 7 julio 1954», RCDIP, 1954, pp. 582-ss.

${ }^{79} \mathrm{La}$ tesis es, realmente, una tesis con raíces decimonónicas, pues fue ya formulada por L. V. BAR y A. PiLlet en relación con la cuestión del orden público internacional. Posteriormente, otros autores, aunque sólo parcialmente, esbozaron rasgos de una teoría más completa. Vid. sólo a título ejemplificativo, A. MAKAROv, «Le cas d'application des régles de conflit étragères», RCDIP, 1955, pp. 431-460; E. M. MEIJERS, «La question du renvoi», Bull. de l'inst. jur.int., 1938, pp. 191-205; L. B. SoHN, «New Bases for Solution of Conflict of Law Problems», Harvard Law Review, 1941-1942, vol. 55, pp. 978-989.

${ }^{80}$ M.-N. JOBARD-BACHELLIER, L'apparence en droit international privé. Essai sur le rôle des représentations individuelles en droit international privé, 1984, p. 95. 
47. c) Tesis de los «derechos adquiridos». Cuando parecía que esta tesis se hallaba ya enterrada y bien enterrada por el paso de los años desde inicios del siglo XX, ahora resurge con fuerza como otra explicación teórica posible (= aunque válida exclusivamente para ciertos supuestos y no para todos), de la «regla de reconocimiento comunitario de situaciones jurídicas» (Anerkennungsprinzip). Se trata, eso sí de nueva versión, muy mejorada y totalmente actualizada, de la antigua y célebre «tesis de los derechos adquiridos» ${ }^{81}$. Aunque existen precedentes estatutarios (H. MUIR-WATT ${ }^{82}$ ), la tesis es creación genuina de la doctrina holandesa del siglo XVIII y debe a U. HuBER su primigenia formulación ${ }^{83}$. Fue exportada con gran éxito a los países angloamericanos, en los que J.H. BEALE y A.V. DiCEY las propagaron con énfasis. Por ello, el DIPr. norteamericano vivió anclado en esta concepción más de cien años hasta que la Conflict-Of-Laws Revolution se convirtió, ya en el siglo xx, en la guillotina fatal de esta tesis de los derechos adquiridos. Según esta tesis (Vested Rights, jura quaesita), existe una regla no escrita de Dere-

${ }^{81}$ Sobre esta tesis, que parece una auténtica ave fénix que nunca termina de extinguirse, vid. P. ARMinJon, «La notion de droits acquis», RCADI, 1933, vol. 44, pp. 11-10; J. K. BEACH, «Uniform Interstate Enforcement of Vested Rights», Yale Law Journal, 27, 1917/18, pp. 656-667; R. D. CARswell, «The Doctrine of Vested Rights in Private International Law», ICLQ, 8, 1959, pp. 268-288; A. FERRER CORREIA, «La doctrine des droits acquis dans un système de règles de conflit bilatérales», Multitudo legum, Ius unum, Festschrift Wilhelm Wengler, vol. II, Berlín, 1973, pp. 285-320; F. LASALLE, Das System der erworbenen Rechte, Teil 1 (Die Theorie der erworbenen Rechte und der Collision der Gesetze), 2. ${ }^{a}$ ed., Leipzig, 1880; A. MiaJA DE LA MuEla, «Los derechos adquiridos en la doctrina española y en el sistema de DIPr. español», ADI, vol. I, 1974, pp. 3-28; H. MüLLER, Der Grundsatz der wohlerworbenen Rechte im internationalen Privatrecht, Geschichte und Kritik, Hamburg, 1935; A. PILLET, «La théorie générale des droits acquis», RCADI, 1925-III, vol. 8, pp. 485-538; W. R. WICHSER, Der Begriff des wohlerworbenen Rechts im internationalen Privatrecht, Zürich, 1955.

${ }^{82} \mathrm{H}$. MuiR-WATT, «Quelques remarques sur la théorie anglo-américaine des droits acquis», RCDIP, 1986, pp. 425-449.

${ }^{83}$ UlRICO Huber, profesor de Derecho en la Frisia oriental y juez, fue el autor del más breve tratado de DIPr. de la Historia. Su título es «De Conflictu Legum diversarum in diversis imperiis» (1689) y su extensión es de cinco cuartillas (= el título engaña). En dicha obra U. Huber expone una doctrina basada en varios puntos. Primero: Las Leyes tienen, por lo general, un efecto territorial que se extiende a los sujetos que residen en el territorio del Estado ya temporal, ya definitivamente. También como regla general, las Leyes no tienen efectos fuera del territorio del Estado. Segundo: Cabe aplicar Derecho extranjero según una «cortesía internacional» (comitas gentium), una «concesión» a los Estados extranjeros para conservar los derechos adquiridos en otros países (Vested Rights). Tercero: Como consecuencia de lo anterior, el Derecho extranjero se debe considerar un «hecho procesal». Cuarto: la aplicación, por vía de la comitas, del Derecho extranjero, debe ser rechazada cuando se vulneren los principios esenciales del Derecho del país cuyos tribunales conocen del asunto. Las tesis de la estatutaria holandesa y en particular, las de U. HUBER, influyeron decisivamente en el DIPr. inglés y americano durante siglos. Por eso, con sólo cinco cuartillas, U. HuBER cambió la Historia del DIPr. y su influencia todavía perdura. 
cho internacional Público (= o de un «Derecho Superior») que ordena a los Estados el respeto a los derechos adquiridos en otros Estados. De ese modo, se respeta la Soberanía extranjera sobre el territorio en el que se han realizado ciertos actos jurídicos (= matrimonios, testamentos, contratos, etc.). Por tanto, con la tesis de los Vested Rigths no se produce, en sentido estricto, una «aplicación del Derecho extranjero». Lo que se produce es un «reconocimiento de los derechos subjetivos adquiridos en el extranjero bajo leyes extranjeras». Estas tesis fueron también defendidas en Europa por ciertos autores, como J. P. Niboyet, A. Pillet y E. Bartin ${ }^{84}$. Pues bien, esta tesis entró en un declive inevitable por distintos motivos: a) No permite responder a la pregunta ¿qué Ley nacional determina si un derecho se ha adquirido o no? Es la famosa «objeción de J. J. MAURY» ${ }^{85}$; b) Olvida que el Derecho extranjero se aplica por mandato de una regla jurídica de la Lex Fori, no por respeto a derechos adquiridos ni por obediencia al Derecho internacional Público: no hay «Derecho Superior» que obligue a «reconocer» situaciones legalmente creadas en otros Estados; c) En ciertas ocasiones, la situación privada internacional se plantea «por primera vez» ante los tribunales de un país. Por ejemplo, la constitución de una sociedad en España por socios ingleses. En este caso, la tesis es inútil. No existe «otro país» con arreglo a cuyas leyes la situación se ha constituido; d) Sostener que con esta tesis no se produce «aplicación del Derecho extranjero» es un sofisma ilusorio creado para evitar los problemas que genera dicha aplicación en relación con la Soberanía del Estado (G. PARRA ARANGUREN ${ }^{86}$ ). Por todo ello, P. ARMinjon escribió, ya en 1933, sin piedad ninguna, que «la noción inconsistente, ambigua y poliforme de los 'derechos adquiridos' no es utilizable en ninguna medida en $D I P r{ }^{87}$. Una frase escrita en 1933, quizás como respuesta ácida al precedente curso de A. PILlET en la Academia de Derecho internacional de La Haya dictado en 1925 (= muy favorable a la tesis de los derechos adquiridos $)^{88}$. Pero los grandes teóricos norteamericanos fustigaron también esta tesis sin ninguna misericordia durante la Conflict-Of-Laws Revolution del siglo Xx. Decía, por ejemplo, A. A. Ehrenzweig, que no existía ese «Derecho superior» y que, por tanto, el First Restatement on the Conflict-OfLaws norteamericano estaba construido sobre basamentos tan endebles, que

\footnotetext{
${ }^{84}$ E. BARTIN, Principes de droit international privé selon la loi et la jurisprudencie françaises, vol. I, París, 1930, esp. p. 195.

${ }^{85}$ J. MAURY, «Règles générales des conflits de lois», RCADI, 1936, vol. 57, pp. 329-563, esp. p. 379.

${ }^{86}$ G. PARra Aranguren, «General Course of Private International Law, Selected Problems», RCADI, 1988, vol. 210, pp. 9-224.

${ }^{87}$ P. Arminjon, «La notion de droits acquis», RCADI, 1933, vol. 44, pp. 1-110, esp. pp. 3-6.

${ }^{88}$ A. PILLET, «La théorie générale des droits acquis», RCADI, 1925-III, vol. 8, pp. 485538.
} 
no se tenía en pie. La «Super-Law» no existía, la teoría de los derechos adquiridos era falsa y las tesis de J. H. BEALE debían ser abandonadas, como efectivamente lo fueron ${ }^{89}$. Por eso escribió K. SIEHR que la única alternativa que frente a la teoría de los derechos adquiridos presentó la Conflict-OfLaws Revolution norteamericana fue la aplicación generalizada de la Lex Fori $^{90}$. En el siglo Xx, ya nadie creía en el método de los derechos adquiridos. Pero los tribunales norteamericanos tampoco creyeron en el método de F. K. VON SAVIGNY, pues ya en el siglo XX, las tesis del maestro prusiano (= norma de conflicto multilateral, igualdad de ordenamientos jurídicos estatales, comunidad de Derecho entre las naciones, localización pura de las situaciones, etc.) se hallaban en un claro declive debido a las enormes disparidades axiológicas entre los Derechos estatales. Y por eso se arrojaron, en mayor o menor medida, en brazos de la Lex Fori y del Jurisdictional Approach.

En la actualidad, la perspectiva adoptada por el TJCE ha revivido la tesis de los derechos adquiridos, con ciertos y muy interesantes matices nuevos. Primero: como indica E. JAYME, en la actualidad, esa Super-Law cuya «no existencia» tanto preocupó a A. A. EHRENZWEIG (= lo que le sirvió para criticar hasta el final la tesis de los Vested Rights en la que se inspiraba el citado First Restatement norteamericano) sí existe. Está formado, para los Estados miembros, por las libertades comunitarias ${ }^{91}$. Segundo: la Soberanía estatal (= que era la explicación y fundamentación última de la tesis de los derechos adquiridos: U. HUBER era un publicista que estaba convencido de que los conflictos de Leyes afectaban a las «relaciones entre los Estados») ya no es necesaria en la regla comunitaria del reconocimiento. No se trata de «respetar» la sociedad de capital creada por un Estado miembro para respetar así la «Soberanía» de dicho Estado miembro sobre su territorio (= donde fue creada o con arreglo a cuyas Leyes fue creada la sociedad de capital). Se trata de respetar lo creado por autoridades de otros Estados miembros (= la sociedad de capital creada por autoridades o por el Derecho de un Estado

${ }^{89}$ A. A. EhrenzweIG, «A Counter-Revolution in Conflicts Law? From Beale to Cavers», Harvard Law Review, vol. 80, 1966, pp. 377-401; A. A. EHRENZWEIG, «The Lex Fori - Basic Rule in the Conflict of Laws», Michigan Law Review, 58, 1959/60, pp. 637-688; ID., «A Proper Law in a Proper Forum: A 'Restatement' of the 'Lex Fori Approach'», Oklahoma Law Review, 18, 1965, pp. 340-352; ID., «Specific Principles of Private International Law», $R C A$ DI, 1968, vol. 124, pp. 167-370; ID., «Wirklichkeiten einer 'lex-fori Theorie'. Zwischen Begriffshimmel der Überrechte und der 'Begriffshölle' des Eigenrechts», en Multitudo Legum. Ius Unum, Festschrift Wilhelm Wengler, vol. II, Berlín, 1973, pp. 251-268.

${ }^{90}$ K. SIEHR, «Ehrenzweig Lex Fori-Theorie und ihre Bedeutung für das amerikanische und deutsche Kollisionsrecht», RabelsZ., 1970, pp. 585-632; ID., «Die lex-fori-Lehre heute», en R. SERICK / H. NIEDERLÄNDER / E. JAYME (Hrsg.), Albert A.Ehrenzweig und das internationale Privatrecht, Heidelberg, 1986, pp. 35-136.

${ }^{91}$ E. JAYME, «Il diritto internazionale privato nel sistema comunitario e i suoi recenti sviluppi normativi nei rapporti con Stati terzi», RDIPP, 2006, pp. 353-360, esp. p. 360. 
miembro), para, de ese modo, construir un mercado único en la UE. El mercado único, y no la Soberanía estatal, explica esta nueva versión de la tesis de los derechos adquiridos. Tercero: el problema teórico más profundo de esta tesis queda solventado: la Ley con arreglo a la cual se adquiere un derecho (= o se crea una situación jurídica, una sociedad, por ejemplo), es la Ley determinada por las normas de conflicto de cada Estado miembro.

48. d) Tesis del «ordenamiento competente» $\mathrm{o}$ «método de coordinación de ordenamientos $»^{92}$. La «regla de reconocimiento comunitario de situaciones jurídicas» (Anerkennungsprinzip) puede también explicarse a través del método defendido por P. PICONE bajo la rúbrica de la «tesis del ordenamiento competente»o «método de coordinación de ordenamientos» ${ }^{93}$. Y el mismo autor hace ya años que propuso la extensión de esta tesis al campo societario $^{94}$. De modo que algunos expertos, como M. V. BenEDETTELLI, opinan

${ }^{92}$ Muy bien explicada por C. FoCARELLI, Lezioni di diritto internazionale privato, Morlacchi Ed., Perugia, 2006, pp. 57-58, mejor incluso que el autor de esta tesis. Esta tesis ha tenido varias versiones debidas todas ellas a su autor originario. Las más elaboradas, y quizás las más completas y sugerentes se pueden encontrar en P. PICONE, «Diritto internazionale privato comunitario e pluralità dei metodi di coordinamento tra ordinamenti», en P. PICONE, Diritto internazionale privato e diritto comunitario, CEDAM, Padua, 2004, pp. 485528. El germen primero de estas tesis se puede ya hallar en P. PICONE, Saggio sulla struttura formale del problema delle questioni preliminiari nel Diritto internazionale privato, Ed. Jovene Napoli, 1971. Una versión más acabada, pero muy complicada, se puede explorar en ID., Ordinamento competente e diritto internazionale privato, Padua, 1986, y en un modo un tanto más comprensible, en P. PICONE, «La méthode de la référence à l'ordre juridique compétent en droit international privé», RCADI, 1986, vol. 197, pp. 229-420.

${ }^{93}$ Lo explica muy bien C. FOCARELLI, Lezioni di diritto internazionale privato, Morlacchi Ed., Perugia, 2006, pp. 57-58, mejor incluso que el autor de esta tesis. Tesis que ha tenido varias versiones debidas todas ellas a su autor originario. Las más elaboradas, y quizás las más completas y sugerentes se pueden encontrar en P. PICONE, «Diritto internazionale privato comunitario e pluralità dei metodi di coordinamento tra ordinamenti», en P. PICONE, Diritto internazionale privato e diritto comunitario, CEDAM, Padua, 2004, pp. 485-528. El germen primero de estas tesis se puede ya hallar en P. PICONE, Saggio sulla struttura formale del problema delle questioni preliminiari nel Diritto internazionale privato, Ed. Jovene Napoli, 1971, obra en la que el autor descubre el nuevo fundamento teórico de la regla de reconocmiento de situaciones jurídicas en la técnica utilizada desde hace años para resolver la compleja problemática de la llamada «cuestión previa de DIPr.», concretamente en la teoría de la Lex Formalis Causae. Una versión más acabada, pero muy compleja, se puede explorar en ID., Ordinamento competente e diritto internazionale privato, Padua, 1986, y un tanto más comprensible, en P. PICONE, «La méthode de la référence à l'ordre juridique compétent en droit international privé», RCADI, 1986, vol.197, pp. 229-420, esp p. 13-15, donde expone, con sumo acierto, la indiferencia del método hacia la cuestión de la determinación de la «Ley aplicable» a la situación jurídica, que no al «ordenamiento competente».

${ }^{94}$ P. PICONE, «Diritto internazionale privato delle società e riconoscimento di Anstalten e Treuunternehmen nell'ordinamento italiano», Communicazioni e Studi, vol. XV, Milán, Giuffrè, 1978, pp. 83-163. 
que la nueva Ley italiana de DIPr. de 31 mayo 1995 ha acogido esta tesis en relación con las personas jurídicas, aunque la cuestión es muy discutida ${ }^{95}$. En suma, esta tesis afirma, en uno de sus postulados, que, para fijar el régimen jurídico de una situación jurídica ya creada en otro país, no debe procederse a la aplicación del Derecho del país «más vinculado con el caso». Por el contrario, la norma de DIPr. debe remitirse, «en bloque», al sistema jurídico del Estado en el que se creó la situación jurídica. La situación jurídica legalmente creada en otro Estado «A» se tiene por existente también en otro Estado «B». Y para nada son relevantes los criterios de competencia judicial internacional ni los criterios de Ley aplicable del Derecho extranjero. Sean cuales sean tales criterios, si la situación jurídica «existe» en un Estado A, o incluso ha sido importada a un Estado «A», entonces tal situación se debe considerar existente en el Estado $« \mathrm{~B} »$.

\section{C) AlCANCE DE LA REGLA}

49. Es necesario precisar la «extensión objetiva» de la «regla de reconocimiento comunitario de situaciones jurídicas» (Anerkennungsprinzip). Los diferentes Estados miembros tienen Derechos societarios distintos. Es posible que un Estado miembro «A» disponga de un tipo concreto de sociedad de capital que no exista en otro Estado miembro «B». En tal caso, la sociedad creada en un Estado miembro «A», ¿puede sobrevivir «como tal» (= con los caracteres y efectos previstos en la Ley de «A»), si se traslada u opera en el Estado miembro «B»? ¿O debe, por el contrario, ser «reconvertida» a cualquier otro tipo societario (= más o menos equivalente) de los expresamente contemplados en $« \mathrm{~B} »$ ?

50. Una primera solución consiste en la «transposición a los tipos societarios del Estado miembro de destino» (= méthode de la substitution). Técnica que ha sido utilizada en Alemania y otros países en ciertos ámbitos, como las garantías mobiliarias o los Civil Partnerships constituidos en otros Estados (K. KREUZER ${ }^{96}$ ). Así, el $§ 17 . b$ número 4 del EGBGB alemán dispone que los efectos en Alemania de una unión civil celebrada en el extranjero no podrán superar los efectos previstos en el Código Civil alemán y en el Lebenspartnerschaftsgesetz. Se sigue también en terceros Estados: el art. 45.3 Ley suiza de Derecho internacional privado de 18 diciembre 1987 precisa que el matrimonio válidamente celebrado en el extranjero entre dos per-

\footnotetext{
${ }^{95}$ M.V. BenEDETTELLI, «La legge regolatrice delle persone giuridiche dopo la riforma del diritto internazionale privato», Rivista delle società, 1997, pp. 39-113.

${ }^{96}$ K. KREUZER, «Sachenreeht», en MünchKomm, vol. 7, Munich, 1990, pp. 2005-2112; ID., «La reconnaissance des sûretés mobilières conventionnelles étrangères», RCDIP, 1995, pp. 465-505.
} 
sonas del mismo sexo será reconocido en Suiza, pero como «unión civil registrada» (= partenariat enregistré) y sólo surtirá los efectos que corresponden, según el Derecho suizo, a dicha «unión civil registrada».

La base teórica de la tesis de la «transposición a los tipos societarios del Estado miembro de destino» es antigua. Radica en la «teoría de la equiparación de los efectos» que en los siglos XIX y XX defendió con brillantez parte de la doctrina italiana (D. Anzilotti, G. Chiovenda, P. Calamandrei, R. QUADRI). Según esta tesis, toda decisión extranjera (= y ahora, toda «situación jurídica» aunque no esté contenida en una sentencia extranjera), debe ser «equiparada» a una decisión nacional y desplegará los mismos efectos que una resolución dictada por una autoridad del Estado requerido (= y ahora, debe ser equiparada a los «tipos societarios» que existan en el Estado miembro de destino). La sociedad creada en otro Estado miembro sufre un proceso de «nacionalización». Su razón de ser se encuentra en la salvaguarda de la Soberanía del Estado de destino: no se aceptan tipos societarios «extraños» si previamente no se «nacionalizan». Aunque la solución presenta la ventaja de no «exterminar» totalmente la sociedad creada en otro Estado miembro, es una solución que merece un completo rechazo. Por varios motivos. Primero: porque atribuye a la sociedad extranjera efectos legales diferentes de Estado miembro a Estado miembro. Segundo: porque la sociedad «extranjera» se «desnaturaliza» (= ya que algunos de sus efectos atribuidos por la Ley con arreglo a la cual se creo la sociedad «se pierden»). La sociedad se «degrada», forzosamente, a un tipo societario conocido en el Estado de destino. Tercero: la solución es nacionalista y legeforista, porque sólo admite las categorías jurídicas y las instituciones del Derecho nacional del Estado miembro de destino (= Lex Fori): el mundo entero y lo que es muy duro, los demás Estados miembros, deben «adaptarse» al Derecho nacional, a las categorías de la Lex Fori. Cuarto: si el Estado miembro de destino no dispone de ningún tipo societario con el que pueda equipararse, más o menos, la sociedad extranjera, esta solución es inútil. En efecto, la sociedad que no encaja en los tipos societarios del Derecho del destino se elimina como tal del mundo jurídico, queda exterminada. Quinto: degradar una sociedad legalmente constituida en un Estado miembro a un tipo societario contemplado en el Derecho del Estado miembro de destino supone un coste y un obstáculo contrario a las libertades comunitarias.

51. Una segunda solución, más adecuada, consiste en que, en principio, la situación legalmente creada en un Estado miembro debe producir en otro Estado miembro los efectos legales previstos en la Ley del Estado miembro de origen ( $=$ o más correctamente, los efectos legales previstos en la Ley que las autoridades del Estado miembro de origen aplicaron al supuesto). La solución es conveniente. Con ello se evita que una misma situación jurídica (= una misma sociedad de capital) surta «efectos distintos» en diferentes Estados miembros. Es decir, de este modo una sociedad de capital concreta 
no será una sociedad de tipo societario «diferente» cada vez que opera en uno u otro Estado miembro. Esta solución es la misma que se ha desarrollado en el ámbito del reconocimiento de decisiones judiciales (= tesis de la «extensión de los efectos» [Gleichstellungslehre]) y que se sigue, por ejemplo, en el Reglamento 44/2001 de 22 diciembre 2000 (vid. STJCE 4 febrero 1988, Hoffmann). El excelente y ya clásico estudio de F. F. GARAU SOBRINO demuestra una superioridad valorativa de la «tesis de la extensión de los efectos» sobre su rival más enconada, la «tesis de la equiparación de los efectos», así como el hecho de que la primera tesis es la que ha seguido y sigue el Derecho positivo español y la inmensa mayoría de los textos legales de fuente internacional ${ }^{97}$.

52. En relación con las sociedades, la posición del TJCE no puede ser más clara en favor de la segunda solución expuesta (= aceptación «tal cual» de la sociedad legalmente creada en otro Estado miembro). Como antes se ha dicho, la sociedad legalmente constituida en el Estado miembro «A» será reconocida y tenida por existente y válidamente constituida en los demás Estados miembros con los efectos y el alcance determinados por la Ley que se aplicó en el Estado miembro de origen (= Estado miembro «A»). Una sociedad holandesa organizada según el Derecho holandés será tenida en cuenta «como tal» (= con arreglo al Derecho holandés) en los demás Estados miembros. Se reconoce la sociedad tal y como se creó en el Estado miembro de origen (V. MAGnieR ${ }^{98}$, S. Leible / J. HofFMAnN ${ }^{99}$ ). Será en Alemania, en España, en Portugal y en cualquier otro Estado miembro de la UE, una «sociedad holandesa». En tal sentido son muy claras las palabras del TJCE: STJCE 9 marzo 1999, Centros FJ 26 in fine ${ }^{100}$, STJCE 5 noviembre 2002, Überseering FJ 93 ${ }^{101}$, FJ 95, que indica expresamente que un Estado

${ }^{97}$ F. F. GARAU Sobrino, Los efectos de las resoluciones extranjeras en España, Madrid, Tecnos, 1992, pp. 28-39.

${ }^{98}$ V. MAGNIER, Rapprochement des droíts dans I'Union européenne et viabilité d'un droit commun des sociétés, LGDJ, 1999, pp. 96-110.

${ }^{99}$ S. Leible / J. HoffMAnN, «Wie inspiriert ist 'Inspire Art'?», EZfW, 2003, pp. 677-683. Idea que ya se encontraba en estado más embrionario en S. LEIBLE / J. HofFMANN, «Überseering und das (vermeintliche) Ende der Sitztheorie», RIW, 2002, pp. 925 y ss.

100 «Las disposiciones del Tratado relativas a la libertad de establecimiento tienen como finalidad precisamente permitir a las sociedades constituidas de conformidad con la legislación de un Estado miembro y cuya sede social, administración central o centro de actividad principal se encuentre dentro de la Comunidad, ejercer por medio de una agencia, sucursal o filial actividades en otros Estados miembros».

101 «[Ninguna medida del Estado miembro de destino (= incluidas sus normas de conflicto de Leyes) puede tener como resultado «que se niegue la capacidad jurídica y, por tanto, la capacidad procesal a una sociedad válidamente constituida en otro Estado miembro en el que tiene su domicilio social estatutario. En efecto, una medida de este tipo equivale a la negación misma de la libertad de establecimiento reconocida a las sociedades por los artículos 43 CE y 48 CE». 
miembro debe reconocer la sociedad creada en otro Estado miembro «como dicha sociedad» (= y no como una «sociedad reconvertida, degradada 0 transpuesta» a los tipos societarios del Estado miembro de destino) ${ }^{102}$, FJ 57, 58 y $59^{103}$ y FJ $81^{104}$.

Es una exigencia derivada de la libertad de establecimiento que las sociedades queden sujetas al Derecho que se aplicó en el Estado miembro de origen a la constitución de dicha sociedad. Así, la sociedad tipo Private Company Limited by Shares creada en Londres será una sociedad tipo Private Company Limited by Shares creada en Londres, será X en toda la UE, en España, Alemania, Portugal, etc. Aunque en tales países no exista dicho tipo societario con las especificaciones propias fijadas por el Derecho inglés (= Private Company Limited by Shares). Degradar o reconvertir la sociedad o transponerla a tipos societarios de cada Estado miembro es obstaculizar, tergiversar y falsear la libertad de establecimiento.

\section{D) El FANTASMa (INEXISTENTE) DEL FRAUdE Y DEL ABUSO DE DERECHO}

53. Otra cuestión a aclarar es la relativa a la posible incidencia del fraude o abuso de Derecho en la «regla de reconocimiento comunitario de situaciones jurídicas» (Anerkennungsprinzip). Ello exige detenerse en varios aspectos.

54. La «regla de reconocimiento de situaciones jurídicas» (Anerkennungsprinzip) es una regla muy generosa. Supone dar carta blanca a las autoridades de otros Estados para crear situaciones jurídicas con la seguridad de

102 «Cuando una sociedad constituida con arreglo a la legislación de un Estado miembro en cuyo territorio se encuentra su domicilio social estatutario ejerce su libertad de establecimiento en otro Estado miembro, los artículos 43 CE y 48 CE obligan a este último a reconocer la capacidad jurídica y, por tanto, la capacidad procesal que dicha sociedad tiene de conformidad con el Derecho de su Estado de constitución».

103 «De lo anterior se deduce directamente que dichas sociedades tienen derecho a ejercer su actividad en otro Estado miembro, sirviendo la localización de su domicilio social estatutario, su administración central o su centro de actividad principal para determinar, a semejanza de la nacionalidad de las personas físicas, su sujeción al ordenamiento jurídico de un Estado miembro. El Tribunal de Justicia basó en estas premisas su razonamiento en el asunto Centros, antes citado (apartados 19 y 20). Pues bien, el ejercicio de la libertad de establecimiento implica necesariamente el reconocimiento de dichas sociedades por todo Estado miembro en el que deseen establecerse».

${ }^{104}$ FJ 81: «Es más, su propia existencia [de la sociedad Überseering] es consustancial a su condición de sociedad neerlandesa en la medida en que, como se ha recordado, una sociedad sólo tiene existencia a través de la legislación nacional que determina su constitución y funcionamiento (véase, en este sentido, la sentencia Daily Mail and General Trust, antes citada, apartado 19). La exigencia de reconstitución de la misma sociedad en Alemania equivale, en consecuencia, a la negación misma de la libertad de establecimiento». 
que éstas serán tenidas como existentes y válidas en otros Estados. Esta «generosidad» sólo es admisible en ciertos contextos. Por ejemplo, en el contexto de una unión federal (= Estados Unidos de América, que disponen de un mecanismo similar a través de la Full Faith and Credit Clause de la Constitución USA) o en un contexto de integración supranacional (= UE). Pero la realidad es que el mundo está dividido en Estados. Estados con Leyes y valores sociales y jurídicos muy dispares, y que no participan en procesos de integración. Por ello, no resulta adecuado admitir y emplear el Anerkennungsprinzip sin límite ninguno en relación con «terceros Estados». Ello supondría tratar el «contexto internacional» o «mundial» (= dividido en Estados muy diferentes con legislaciones muy diferentes), como un «contexto de integración» (= toda solución jurídica adoptada en un país sería jurídicamente válida y eficaz en todos los demás países, como si el mundo fuera «una Confederación» o una «Unión Mundial de Estados»). Eso sería una «falsa analogía». Por ello, es conveniente trazar una distinción: 1. $\left.{ }^{\circ}\right)$ El Anerkennungsprinzip debe operar de la manera más extensa sólo en «contextos de integración» supranacionales o federales, porque así se eleva el grado de integración de los Estados integrados y se realizan verdaderamente las libertades de circulación; $2^{\circ}$ ) Fuera de tales contextos (= es decir, en relación con «terceros Estados»), el Anerkennungsprinzip puede también emplearse, pero debe quedar sometido a ciertos límites. Tradicionalmente, se han empleado dos límites: a) el orden público internacional (= la regla no opera si la situación creada en otro Estado produce efectos legales contrarios a los principios básicos del Estado de destino); b) el control de la competencia de la autoridad del Estado origen (= no se pueden dar efectos en un Estado a las situaciones jurídicas creadas por autoridades de otros Estados que «se exceden» en sus competencias y crean situaciones jurídicas muy escasamente conectadas con tales Estados). Estos supuestos suelen ser denominados por ciertos autores como casos de «fraude» y/o «abuso de Derecho». Se trata, en este momento, de comprobar si estos límites pueden y/o deben operar en relación con esta «regla de reconocimiento de situaciones jurídicas» (Anerkennungsprinzip) pero en el ámbito de la UE. Porque las situaciones jurídicas deben recibir un tratamiento legal diferente según hayan sido creadas en un Estado miembro o en tercer Estado. De ese modo, y sólo de ese modo, la UE puede aspirar a operar como un espacio de seguridad, libertad y Justicia y como un auténtico mercado único. Al respecto, varias consideraciones son necesarias.

55. Primera: el contenido de la Ley aplicada por la autoridad del Estado miembro de origen no es relevante. En el marco de la UE, el Anerkennungsprinzip debe operar sin que se pueda practicar un «control de la Ley aplicada» ni la excepción de «fraude» ni de «abuso de Derecho». En una comunidad jurídica como es hoy la UE, la regla general debe ser, precisamente, la libre circulación de situaciones jurídicas. De este modo, un Estado 
miembro debe admitir la existencia y validez de una situación jurídica (= sociedad/persona jurídica, por ejemplo), creada legalmente en otro Estado miembro con arreglo a las normas de conflicto de Leyes de ese Estado miembro. Resulta muy difícil aceptar que otro Estado miembro disponga de «Leyes injustas» o «Leyes odiosas» en el contexto del Derecho de sociedades. Todos los Estados miembros disponen de legislaciones que garantizan una alta calidad de regulación. Por eso son «legislaciones intercambiables» (= en el sentido de que la aplicación de una u otra legislación de uno u otro Estado miembro no debe activar la cláusula de «orden público internacional»). La «libre circulación de situaciones jurídicas» es necesaria para lograr un espacio sin fronteras ni obstáculos a la libre circulación de personas físicas y jurídicas en la UE. Y eso sólo se logra plenamente si la excepción del orden público internacional desaparece del mapa jurídico de la UE. Corolario final: los particulares pueden acudir al Estado miembro que prefieran para constituir una persona jurídica, sin que, por ello, puedan ser acusados de realizar un «By-Pass jurídico» en favor de una «Ley intolerable» por ser demasiado permisiva o por cualquier otra circunstancia.

56. Segunda: la competencia de las autoridades de un Estado miembro para la constitución de sociedades. En relación con «terceros Estados», la exigencia de que la situación creada en un Estado presente vínculos objetivos con dicho Estado es una condición necesaria. De ese modo, se evita que los particulares «escapen» a la Ley del país con el que la situación está naturalmente o razonablemente vinculada y busquen la cobertura de una «Ley permisiva» que se corresponde con un país que, realmente, nada tiene que ver con el asunto. La internacionalización ficticia de casos internos ha sido una constante en la Historia del DIPr. Ha sido y es muy frecuente que los particulares se desplacen a otros países para obtener divorcios, celebrar matrimonios, firmar contratos, constituir derechos reales y también constituir sociedades, en casos en los que tales operaciones jurídicas no eran posibles con arreglo al Derecho del país «naturalmente vinculado» con el supuesto. La justificación última de la prohibición de «internacionalizar» casos «internos» no se halla exclusivamente en el contenido del Derecho extranjero aplicado por las autoridades extranjeras (= en ese caso, la cláusula de orden público internacional resolvería satisfactoriamente la cuestión). La justificación última de esta prohibición radica en la «estructura jurídica del mundo». El mundo está dividido en Estados. Cada Estado dispone de sus Leyes, que entiende, naturalmente, que son «las mejores» para regular las situaciones jurídicas. Pues bien, un Estado no acepta la internacionalización ficticia de las situaciones jurídicas puramente internas porque ello implicaría tratar al «mundo» (= que está compuesto por multitud de Estados soberanos muy distintos) como una «comunidad de Naciones» o como una «unión de Estados» que presenta un elevado grado de integración. Pero las cosas no son así. 
El mundo no es, en su totalidad, «una comunidad de Estados» que persigue la integración. El mundo es una realidad dividida en Estados independientes, soberanos, muy diferentes y con sistemas jurídicos anclados en valores muy distintos cuando no opuestos y enfrentados. Ésta es la explicación última de la prohibición de «internacionalizar situaciones jurídicas exclusivamente internas». Las situaciones «naturalmente conectadas con un Estado» (= todos sus elementos están conectados con un solo Estado) deben regirse por la Ley de ese Estado. Es el «ámbito natural» de las Leyes de ese Estado. Es lo que P. LAGARDE llama «el respeto a la autoridad de la Ley» (= l'autorité de la loi $)^{105}$. El Estado elabora sus Leyes para regular una comunidad social determinada (= aquella comunidad sobre la que, de modo natural, ejerce sus competencias legislativas). Las Leyes de un Estado rigen las situaciones enteramente vinculadas con dicho Estado. Sólo de ese modo queda salvaguardada la «autoridad de la Ley» y se garantiza que tales Leyes puedan cumplir con el fin para el que han sido dictadas: hacer Justicia en relación con una concreta comunidad social. Las Leyes españolas persiguen ofrecer regulaciones justas destinadas a la comunidad social española. $\mathrm{Si}$ ciertas relaciones jurídicas enteramente integradas en la comunidad social española (= por ejemplo, una sociedad de capital cuya totalidad de elementos están vinculados con España) quedan sustraídas a las Leyes españolas, la autoridad de la Ley queda dañada. La Ley no podría entonces cumplir con su misión de Justicia. La división del mundo en Estados exige el respeto a la «autoridad de la Ley». Por ello, cuando una relación social ha sido artificialmente sustraída al ámbito de las Leyes de un Estado concreto, es necesario un control de la competencia de las autoridades que constituyen dicha situación jurídica. Ese control es necesario para salvaguardar la «autoridad de la Ley» del Estado de destino y para evitar así el llamado Bad Forum Shopping. Ejemplo: si una sociedad de capital cuya totalidad de elementos están vinculados con España se somete por los socios fundadores a la Ley de Delaware y se constituye con arreglo a dicha Ley, resultará que las Leyes españolas en

${ }^{105}$ Escribe P. LAGARDE: «la faveur à la validité des situations juridiques, qui inspire de telles règles, est cepedant soumise à certaines conditions. Il ne peut s'agir de reconnaître n'importe quelle situation crée n'importe où. Indépendamment de la condition de conformité à l'ordre public, la reconnaissance peut être subordonnée, non pas à l'application d'une certaine loi, mais à l'existence de certains liens de la situation avec son État d'origine». P. LAGARDE, «Conflits de lois (Principes généraux)», Répertoire Dalloz Droit International, enero 2006, pp. 1-30, esp. p. 30; ID., «Développements futurs du droit international privé dans une Europe en voie d'unification: quelques conjectures», RabelsZ, 2004, pp. 225-243. Vid. igualmente, H. BATIFFol / P. LAGARDE, Droit international privé, t. I, 8. ${ }^{\mathrm{a}}$ ed., LGDJ, París, 1993, p. 446: "Il semble en effet que l'intérêt essentiel de l'État consiste à assurer l'homogénéité et l'autorité de la sa loi; les lois édictées par un État forment un ensemble; si on soustrait à cet ensemble des relations étroitement unies à celles auxquelles il s'applique sans conteste, il en résultera inévitablement des incohérences, des contradictions et une atteinte à l'autorité de la loi». 
materia societaria quedan «puenteadas». Una sociedad enteramente integrada en el contexto español queda así sustraída a la acción de las Leyes españolas. Tales Leyes no pueden, en dicho caso, realizar sus objetivos. La autoridad de dicha Ley se ve perjudicada. Por ello es preciso impedir estas maniobras de los particulares que «aprovechan» el contexto internacional (= el hecho de que el mundo está dividido en Estados) para sustraer su sociedad al alcance natural de las Leyes españolas.

Sin embargo, en el contexto comunitario, todo cambia. La UE es algo más que la «suma cuantitativa de Estados». Es una comunidad jurídica, un espacio de seguridad, libertad y Justicia con un único mercado. Ello exige que, sobre la base del «principio de confianza comunitaria», los Estados miembros acepten la posibilidad de que los particulares sitúen la creación de una sociedad de capital en el Estado miembro de que se trate. Sólo de ese modo, los particulares pueden aprovecharse de las ventajas de un gran mercado comunitario y de las libertades de circulación. Que es de lo que se trata. «Fraude» y «abuso de Derecho» no pueden existir en la UE por el hecho de «ubicar la constitución de una sociedad» en un concreto Estado miembro. La UE no es «un solo Estado», pero los Estados miembros comparten un mismo destino y se hallan comprometidos en la integración europea y en la creación y en el funcionamiento de un mercado único. Este dato lo cambia todo. En efecto: sólo puede hablarse de tales correctivos (= orden público internacional, fraude de Ley, abuso de Derecho, Bad Forum Shopping, control de la competencia de la autoridad del Estado de origen), referidos a la «constitución de sociedades», en relación con «terceros Estados». Naturalmente, el fraude o abuso de Derecho es un límite de toda regla general. También de la libertad de establecimiento y también del Anerkennungsprinzip. Pero dicho límite sólo puede operar en relación con aspectos diferentes a la constitución de una sociedad de capital. Por ejemplo, cuando se pretende luchar contra la evasión fiscal a través de una legislación específica y una sociedad crea una filial en un Estado miembro con el objetivo, exclusivo, de imputarle transacciones que la filial, realmente, no realiza (= pues las realiza la sociedad-madre, radicada en otro Estado miembro con carga impositiva más elevada), de modo que la carga impositiva total del grupo societario resultaba ser muy inferior. Eso es lo que llama el Abogado General Sr. Philippe Léger, en sus Conclusiones presentadas el 2 mayo 2006, en el as. C/196/04, Cadbury Schweppes plc, Cadbury Schweppes Overseas Ltd vs. Commissioners of Inland Revenue, «un «montaje artificial» que pervierte la libertad de establecimiento y que justifica que una empresa no pueda beneficiarse de la libertad de establecimiento en el caso concreto ${ }^{106}$.

${ }^{106}$ Conclusiones del Abogado General Sr. Philippe Léger presentadas el 2 mayo 2006, en el as. C/196/04, Cadbury Schweppes plc, Cadbury Schweppes Overseas Ltd vs. Commissioners of Inland Revenue: «los órganos jurisdiccionales nacionales pueden en cada caso 
57. A modo de recapitulación, puede afirmarse que la «regla de reconocimiento de situaciones jurídicas» (Anerkennungsprinzip) debería operar en el contexto de la UE sin ningún límite de orden público internacional, fraude de Ley, abuso de Derecho, Bad Forum Shopping o control de la competencia del juez de origen (= en un «contexto de integración», dichos correctivos resultan inapropiados porque impiden la misma integración de los Estados miembros). Por el contrario, fuera de un contexto de integración (= con terceros Estados), tales límites al Anerkennungsprinzip deben operar para defender la «autoridad» de la Ley del Estado de destino.

\section{E) FoRMULACiÓN LEGAL Y JUDICIAL DE LA REGLA}

58. La «regla de reconocimiento comunitario de situaciones jurídicas» (Anerkennungsprinzip) no existe como solución de Derecho positivo a fecha 13 septiembre 2006. Pero existe. Actualmente se aplica como una regla de «desarrollo judicial del DIPr.» que la jurisprudencia del TJCE ha admitido expresamente en varios pronunciamientos de extraordinaria importancia. $\mathrm{Si}$ hay que ceñirse a la materia societaria (= que tampoco hay por qué, ya que la regla ha sido empleada por el TJCE en otras áreas jurídicas, como en el derecho al nombre de las personas físicas), dicha regla ha sido expresamente bendecida por el TJCE en la citada y célebre trilogía societaria compuesta por las sentencias STJCE 9 marzo 1999, Centros, STJCE 5 noviembre 2002, Überseering, STJCE 30 septiembre 2003, Inspire Art, antes referenciadas.

59. Como es evidente, dicha regla podría traducirse, en el futuro, en una norma de Derecho Positivo comunitario. Bastaría que las autoridades comunitarias crearan una «regla de reconocimiento comunitario de situaciones jurídicas» (Anerkennungsprinzip). En virtud de dicha regla, toda situación jurídica legalmente creada en un Estado miembro con arreglo a sus normas nacionales de conflicto de Leyes y con independencia de la «Ley estatal» que la autoridad del Estado miembro de origen aplicó a la situación jurídica, sería considerada existente y válida en los demás Estados miembros. Y dicha cláusula de validez comunitaria de las situaciones jurídicas podría diseñarse de «modo general». En tal caso, sería aplicable no sólo para determinar la

concreto, basándose en elementos objetivos, tener en cuenta el comportamiento abusivo o fraudulento de las personas afectadas a fin de denegarles el beneficio de las disposiciones de Derecho comunitario invocadas. De lo anterior se deduce que, para que pueda estar justificada por la lucha contra la evasión fiscal, la legislación nacional no debe limitarse a referirse a una situación definida en términos generales, sino que debe permitir al juez. nacional denegar, en cada caso concreto, el beneficio del Derecho comunitario a determinados contribuyentes o a determinadas sociedades que hayan realizado un montaje artificial con la finalidad de eludir el impuesto». 
«Ley reguladora» de las sociedades, sino la Ley reguladora o, melius, la «validez comunitaria» de toda situación legalmente creada en un Estado miembro (= testamentos, sociedades, filiación, nombre de la persona, etc.).

4. Segunda solución: la técnica del conflicto de Leyes y la unificación futura de las normas de conflicto de los Estados miembros en materia societaria

\section{A) COMUNITARIZACIÓN DE LAS NORMAS DE CONFLICTO SOCIETARIAS}

60. Una segunda solución, alternativa a la anterior, es también posible con el objetivo de evitar los «cambios de Ley aplicable» que provocan obstáculos a las libertades comunitarias (E. JAYME ${ }^{107}$ ).

61. La segunda solución consiste en elaborar «normas de conflicto uniformes» por parte de las autoridades comunitarias. Tales normas deberían ser Derecho vigente uniforme para todos los Estados miembros (= todos los Estados miembros tendrían las mismas normas de conflicto en materia societaria). Dichas normas de conflicto señalarían la «Ley aplicable» a una situación jurídica (= a una sociedad) creada legalmente en otro Estado miembro. De ese modo, una situación existente y válida en un Estado miembro (= ejemplo: una Private Company Limited by Shares «incorporada» al Derecho inglés) sería siempre considerada existente y válida en los demás Estados miembros, pues el «cruce de frontera» no implicará ningún «cambio de Ley aplicable».

62. El Derecho comunitario ya dispone de normas de conflicto uniformes en ciertos sectores. Ejemplo: el Convenio de Roma de 19 junio 1980 sobre la Ley aplicable a las obligaciones contractuales indica que, si los contratantes no disponen otra cosa, un contrato de compraventa se rige, como regla general, por la Ley del país de establecimiento del vendedor. Si un vendedor austríaco firma un contrato con un comprador español, ese contrato, válido en Austria, será, lógicamente, también válido en España, pues los tribunales y autoridades austríacas y españolas aplican las mismas normas de conflicto para valorar la existencia y validez del contrato. La situación «legalmente nacida en Austria» es considerada «legalmente existente en España».

${ }^{107}$ E. JAYME, «Il diritto internazionale privato nel sistema comunitario e i suoi recenti sviluppi normativi nei rapporti con Stati terzi», RDIPP, 2006, pp. 353-360; E. JAYME / CH. KÖHLER, «Europäisches Kollisionsrecht 2001: Anerkennungsprinzip statt IPR?», IPrax, 2001, pp. 501-512, esp. p. 504. 
63. Si esta solución se proyecta al campo de las sociedades en la UE, el resultado es claro. Si la Ley aplicable a las sociedades fuera, en virtud de una futura y eventual norma de conflicto comunitaria uniforme, la Ley del Estado con arreglo a la cual se ha constituido la sociedad (= tesis de la Incorporation), pues resultaría que una sociedad creada en Irlanda con arreglo al Derecho irlandés sería considerada, lógicamente, como una sociedad válidamente constituida y plenamente existente en España, porque las autoridades españolas aplicarían, para decidir en torno a la validez y existencia de la sociedad en cuestión, la Ley irlandesa, es decir, la misma Ley que aplicó la autoridad irlandesa a la constitución de la sociedad. Las autoridades españolas aplican la misma Ley material que aplicó la autoridad irlandesa, porque Irlanda y España dispondrían de la misma norma de conflicto en materia de sociedades. Igualdad de norma de conflicto significa igualdad de Ley aplicable en todos los Estados miembros. El enfoque cambia, porque «no se reconoce» una sociedad creada en otro Estado miembro. Por el contrario, se vuelve a someter a un proceso de determinación de la Ley aplicable a la sociedad. Parece complicado y un tanto innecesario (= la determinación de la Ley aplicable se debe hacer «dos veces» y además con idéntico resultado). Pero presenta una ventaja teórica: se elimina el Forum Shopping. Si las normas de conflicto son iguales en todos los Estados miembros, ningún particular podrá extraer ninguna ventaja oportunista si sitúa la cuestión en las manos de los jueces o autoridades belgas, franceses o ingleses. Todas las autoridades de los Estados miembros aplicarán las mismas normas de conflicto y la misma Ley sustantiva al fondo de la cuestión.

64. Para que esta solución sea posible, es imprescindible profundizar en el proceso conocido como la «comunitarización del DIPr» ${ }^{108}$. La «comunita-

${ }^{108}$ Este proceso ha sido y es objeto de profundos debates y estudios en toda la doctrina europea. Vid., entre otros muchos, A.-L. CAlvo CARAvaCA, «El DIPr. de la Comunidad Europea», International Law. Revista colombiana de Derecho internacional, núm. 2, diciembre 2003, pp. 277-300; S. BRUINIER, Der Einflusss der Grundfreiheiten auf das internationale Privatrecht, Frankfurt am Main, Lang, 2003; L. DE LIMA PINHEIRO, «Federalismo e Direito Internacional Privado - algumas reflexões sobre a comunitarização do Direito Internacional Privado», en D. Moura VICENTE (Coord.), Direito Comparado. Perspectivas Luso-Americanas, Comparative Law. Portuguese-American Perspectives, vol. I, Coimbra, Almedina, 2006, pp. 275-300; P. De Miguel Asensio, «El Tratado de Amsterdam y el DIPr.», La Ley UE, 30 marzo 1998, pp. 1-3; H. DoHRN, Die Kompetenzen der Europäischen Gemeinschaft im Internationalen Privatrecht, Tübingen, Mohr Siebeck, 2004; S. FRANCQ, L'applicabilité du droit communautaire dérivé au regard des méthodes du droit international privé, Bruylant-L.G.D.J., París, 2005; H. GAUDEMET-TALLON, «De l'utilité d'une unification du droit international privé de la famille dans l'Union Européenne», Estudos Magalhães Collaço, vol. I, Almedina, Portugal, 2002, pp. 159-185; ID., «Quel Droit International Privé pour l'Union Européenne?», en P. J. BORCHERS / J. ZEKOLL (EDS.), International Conflict of Laws for the Third Millennium, Essays in Honor of F. K. Juenger, Transnational Publishers/ 
rización del DIPr.» consiste en lo siguiente: los arts. 61 c y 65 TCE -en la redacción dada por el Tratado de Amsterdam de 2 octubre 1997, en vigor desde el 1 mayo 1999-, atribuyen, en ciertos términos, a las instituciones comunitarias la competencia para adoptar medidas con el objetivo de desarrollar «una cooperación judicial en asuntos civiles con repercusión transfronteriza», con el fin de «establecer progresivamente un espacio de libertad,

Ardsley, Nueva York, 2001, pp. 319-338; K. Boele-WoelKI, «Unification and Harmonisation of Private International Law in Europe», Private Law in the International Arena, Liber Amicorum K. Siehr, TMC Asser Press, The Hague, 2000, pp. 61-77; TH. M. DE BoER, «Prospects for European Conflicts Law in the Twenty-First Century», en P.J. BorCHERS / J. ZeKoll (EDS.), International Conflict of Laws for the Third Millennium, Essays in Honor of F. K. Juenger, Transnational Publishers/Ardsley, Nueva York, 2001, pp. 193-214; S. LeIBLE / A. STAUDINGER, «El art. 65 TCE: ¿carta blanca de la Comunidad Europea para la unificación del DIPr. y procesal?», AEDIP, vol. I, 2001, pp. 89-115; F. POCAR, «La comunitarizzazione del DIPrivato: una european conflict of laws revolution», RDIPP, 2000, pp. 873-884; S. BARIATTI, «Prime considerazioni sugli effetti dei principi generali e delle norme materiali del trattato CE sul diritto internazionale privato comunitario», RDIPP, 2003, pp. 671-706; S. BARIATTI, «Qualificacione e interpretazione nel diritto internazionale privato comunitario: prime riflessioni», RDIPP, 2006, pp. 361-376; J. BASEDOw, «The communitarisation of the conflict of laws under the treaty of Amsterdam», $C M L R$, 2000, p. 687-ss.; ID., «European Conflict of Laws Under the Treaty of Amsterdam», en P. J. Borchers / J. ZeKoll (EDS.), Essays F. K. Juenger, Nueva York, 2001, pp. 175-192; M. HerRero RodríGueZ DE Miñón, «Desde el 'mientras que' hasta el 'sí, salvo' (la jurisprudencia constitucional ante el Derecho europeo)», REDI, 2005, vol. 57, pp. 89-104; E. JAYME, «Il diritto internazionale privato nel sistema comunitario e i suoi recenti sviluppi normativi nei rapporti con Stati terzi», RDIPP, 2006, pp. 353-360; E. JAYME / CH. KOHLER, «L'interaction des règles de conflit contenues dans le droit dérivé de la Communauté Européenne et des conentions de Bruxelles et de Rome», RCDIP, 1995, pp. 25 ss.; H. U. Jessurun D'Oliveira, «The EU and a metamorphosis of Private International Law», Essays P. North, Oxford UP, 2002, pp. 111-136; CH. KOHLER, «Lo spazio giudiziario europeo in materia civile e il diritto internazionale priovato europeo», en P. PICONE, Diritto internazionale privato e diritto comunitario, CEDAM, Padua, 2004, pp. 65-94; ID., «Interrogations sur les sources du droit international privé européen après le traité d'Amsterdam», RCDIP, 1999, pp. 1-30; P. LAGARDE, «Développements futurs du droit international privé dans une Europe en voie d'unification: quelques conjetures», RabelsZ, 2004, pp. 225-243; D. LEFRANC, «La spécificité des règles de conflit de lois en droit communautaire dérivé (aspects de droit privé)», RCDIP, pp. 413-446; PH.-E. PARTSCH, Le droit international privé européen de Rome a Nice, Bruxelles, Lacier, 2003; P. PICONE (a cura di), Diritto internazionale privato e Diritto comunitario, Cedam, Padua 2004; F. Viangalli, La théorie des conflits de lois et le droit communautaire, Aix-en Provence, Presses Univ. d'Aix-Marseille, 2004; R. WAGNER, «EG-Kompetenz für das Internationale Privatrecht in Ehesachen?», RabelsZ, 2004, pp. 119-153; K. WANNEMACHER, Die Aussenkompetenzen der EG im Bereich des Internationalen Zivilverfahrensrechts: des räumliche Andwendungsbereich des Art. 65 EGV am Beispel der EuGVO und der EheVO, Frankfurt am Main, Lang, 2003; M. WILDERSPIN / A.-M. ROUCHAUD-JoËT, «La compétence externe de la Communauté européenne en droit international privé», RCDIP, 2004, pp. 148. Imprescindible es la lectura y comprensión del Dictamen TJCE de 7 febrero 2006 (Lugano II)). Vid. A.-L. Calvo Caravaca / J. Carrascosa González, Derecho Internacional Pri-

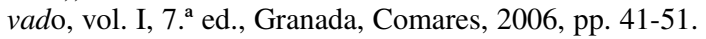


de seguridad y de justicia» (art. $61 \mathrm{TCE}$ ). En otras palabras: las autoridades comunitarias disponen de competencia para elaborar «normas de DIPr.» que sirvan para construir un «espacio de libertad, de seguridad y de justicia» en la UE, mientras que los Estados miembros pierden progresivamente la posibilidad de elaborar «normas de DIPr.». La raison d'être de la «comunitarización del DIPr.» radica en que dicho proceso es necesario porque la diversidad de sistemas de Derecho Privado en la UE suscita «obstáculos para la libre circulación de las personas en la UE». Si una sociedad legalmente creada en Irlanda puede ser considerada como no existente o irregular en España, la libertad de establecimiento de las sociedades se ve perjudicada. La solución de crear normas uniformes comunitarias de conflicto de Leyes exige comunitarizar el DIPr. Así ha ocurrido en virtud del art. 65 TCE (= vid. también, «Proyecto de medidas para la aplicación del principio de reconocimiento mutuo de las resoluciones judiciales en materia civil y mercantil» (DOCE C12, de 15 enero 2001). Pues bien, el art. 61.c TCE atribuye a las autoridades comunitarias la competencia para elaborar normas de DIPr. dirigidas a construir un «espacio de seguridad, libertad y justicia en la UE», y «en la medida necesaria para el correcto funcionamiento del mercado interior». Dicha competencia es «compartida» entre la UE y los Estados miembros. Pero si las instituciones comunitarias regulan un concreto aspecto de DIPr., la materia regulada pasa a ser «competencia privativa de la UE» y los Estados comunitarios ya no pueden legislar sobre la materia.

\section{B) Hacia una victoria de la Incorporation Theory}

65. En febrero de 2006 se dio a conocer una propuesta alemana para la elaboración de un futuro Reglamento comunitario en materia societaria que se sitúa en esta línea (= Proposal of the Deutscher Rat für Internationales Privatrecht for European and national legislation in the field of international company law, diseñada por los Profs. H. J. SONNENBERGER / F. BAUER ${ }^{109}$ ). Este futuro Reglamento comunitario sobre la materia cubriría no sólo las sociedades cuya sede estatutaria se hallare en un Estado miembro, sino aquéllas con sede estatutaria de la UE (= en este sentido, sería un Reglamento erga omnes: art. 1.1 Propuesta, lo que puede llevar a la aplicación de la Ley

\footnotetext{
${ }^{109}$ El texto puede examinarse en lengua alemana en Recht der Internationalen Wirschaft (RIW), 2006, suplemento n. 1 del fascículo 4 abril 2006. Existe traducción italiana en Rivista di diritto internazionale privato e processuale, (RDIPP), 2006-III, pp. 876-871, con comentario extenso de P. KINDLER, «Aspetti essenziali di un futuro regolamento comunitario sulla legge applicabile alle società», en la misma revista y número, pp. 657-674. Existe también traducción al idioma inglés proporcionada por el Max Planck Institut for Comparative and Private International Law, que es la que ha sido utilizada predominantemente en este trabajo.
} 
de un tercer Estado). Y abarca también los entes que no persiguen fin de lucro (= lo que sobrepasa la letra del art. 58 TCE: art. 1.2 de la Propuesta germana).

Con arreglo a su artículo 2, las sociedades quedarán sujetas a la Ley del Estado en cuyos registros han sido inscritas. Como es natural, se supone que una sociedad se inscribe en el Registro Público del país con arreglo a cuyas Leyes se ha constituido, que coincide con el país donde tiene su sede estatutaria (P. KINDLER ${ }^{110}$ ). Si se trata de sociedades que no necesitan inscripción pública, se regirán por la Ley del Estado con arreglo a la cual se han constituido (= Incorporation Theory en estado puro), y si tal Ley no puede ser determinada, se aplicarán las normas de conflicto relativas a los contratos internacionales ${ }^{111}$. Como se observa, la propuesta acoge la «tesis de la incorporación» y ninguna mención se realiza a las demás tesis conflictuales en el campo societario (= sede de dirección, lugar de explotación principal, etc.). Una vez que una sociedad, por ejemplo, ha sido inscrita en Bélgica con arreglo a los requisitos exigidos por las Leyes belgas, dicha sociedad podrá operar libremente en España y será considerada, en España, como existente y válidamente constituida. No importará su lugar de explotación principal o su sede de dirección. Aunque todas sus actividades comerciales se desarrollen en España, seguirá sujeta al Derecho belga en toda su extensión.

66. Una norma de conflicto comunitaria en materia de sociedades sólo puede acoger un criterio: la Incorporation Theory (= la sociedad se rige por la Ley del Estado con arreglo a la cual se ha constituido). La predilección por la Incorporation Theory no es un homenaje el Imperio británico ni tampoco es un vasallaje al amigo americano. Es, simplemente, «la mejor regla posible de DIPr. en materia societaria» (U. ULMER ${ }^{112}$ ). Escribe categóricamente, y con toda razón, F. J. GARCiMARTín Alférez, que la tesis de la incorporación «es la que resulta más compatible con las exigencia del Tratado CE» $\mathrm{y}$, con otras palabras, indica este autor en que «el único modelo compatible con

${ }^{110}$ P. KINDLER, «Aspetti essenziali di un futuro regolamento comunitario sulla legge applicabile alle società», RDIPP, 2006-III, pp. 657-674, esp. p. 657.

${ }^{111}$ Art. 2: «Applicable law. (1) Companies shall be subject to the law of the state in whose public register they are entered. (2) If they are not or have not yet been registered in a public register, they shall be subject to the law of the state under whose law they are organised. If the applicable law cannot be determined pursuant to sentence 1 , the conflict-oflaws rules applicable to contractual obligations shall apply. If a company purports to operate under a law other than that determined pursuant to sentence 1 or 2, a third party acting in good faith may invoke such law».

${ }^{112}$ U. ULMER, «Schutzinstrumente gegen die Gefahren aus der Geschäftstätigkeit inländischer Zweigniederlassungen von Kapitalgesellschaften mit fiktiven Auslandssitz», JZ, 1999, pp. 662-680. 
el Tratado [CE] es el de constitución/incorporación» ${ }^{113}$. Y especialmente es así en un ámbito de integración, como la UE, en el que el principio de confianza comunitaria juega un papel estelar. La tesis de la sede real, en cualquiera de sus variantes, no puede adoptarse como regla general en una futura norma de conflicto comunitaria, porque comportaría «cambios de la Ley aplicable» a la misma sociedad cada vez que cambiara el lugar de sus actividades económicas principales o el lugar desde donde se dirige la sociedad. Y este «cambio de Ley aplicable» comportaría una intolerable lesión a la libertad de establecimiento protegida por los arts. 43-48 TCE. Por tanto, como ha señalado J. KosYRIS ${ }^{114}$, Europa camina inexorablemente, y hace bien, hacia la «cuasi-canonización» de la Incorporation Theory. Algo que los Estados Unidos de América ya hace mucho que practican con ciertas diferencias de matiz, a través de la famosa Full Faith and Credit Clause de rango constitucional.

67. Más preocupante, aunque realmente privada de todo efecto práctico real, resulta la previsión de la Propuesta germana relativa al «abuso de Derecho». Se dice que en virtud de dicha cláusula, cuando se utilice de modo fraudulento (= Abuse of Law) el registro de una sociedad para evitar las exigencias de la legislación societaria del país de establecimiento de la sociedad, no debe aplicarse la Ley del Estado de registro de la sociedad ${ }^{115}$. Esta previsión es infundada e innecesaria. Primero, porque como reconoce la mis-

${ }^{113}$ F. J. Garcimartín AlféReZ, Derecho de sociedades y conflictos de leyes: una aproximación contractual, Cuadernos Mercantiles, Ed. de Derecho Reunidas, Madrid, 2002, pp. 306-311.

114 J. KosYRIS, «Some Observations on State Regulation of Multistate Takeover: Controlling Chioice of Law Through the Commerce Clause», Delaware Journal of Corporation Law, 14, 1989, pp. 499-520, esp. p. 505.

115 «Where a legal system or place of registration is chosen abusively and this constitutes an abuse of the freedom of establishment within the meaning of the ECJ's case-law, this may be a legitimate ground for using the actual centre of administration as the connecting factor. This is consistent with the general IPL doctrine that no account is to be taken of the abusive exploitation of a relationship to engineer the application of a connecting factor with a view to either achieving or circumventing a particular outcome under the substantive law of a Member State. The committee's deliberations revealed that cases in which abusive recourse to or circumvention of a particular system of company law might come into question are likely to be extremely rare. The choice of a different legal system by way of registration with a view to enjoying benefits under the company law selected is, in principle, a form of exercising the freedom of establishment. Cases in which the application of a different system of company law is engineered in order to circumvent any incompetence or disqualifying provisions were given as examples of abuse. The committee agreed that such cases must be ruled out. Given that the necessary measures would ultimately constitute prohibitions on the exercise of a profession, the committee was strongly in favour of removing this specific issue from the scope of company law by way of exceptional connecting factors to the law governing mandatory rules (...) Moreover, recourse to a general clause on abuse, which is recognised as an unwritten element of private law and thus of the law on renvoi (fraus omnia corrumpit), has in the past proven to be necessary in only a few isolated 
ma propuesta alemana, la elección de una Ley estatal concreta a través del registro en el país correspondiente es un modo plenamente legítimo de ejercer la libertad de establecimiento. Segundo, porque emplear la cláusula de «fraude de Ley» en este campo legal, supone aceptar que existen «Leyes odiosas» de ciertos Estados miembros, que no satisfacen unos «estándares mínimos de Justicia». Leyes cuya elección por las partes hay que evitar. La cláusula de fraude de Ley opera, en estos casos, como un orden público internacional «oculto» o maquillado al que no se desea dar ese nombre (= pero que es realmente un orden público internacional que rechaza la aplicación del Derecho de otro Estado miembro porque se considera que su contenido es «injusto»y «odioso»). Este planteamiento es inaceptable en una auténtica «comunidad jurídica» como es hoy la UE.

\section{Perspectiva comunitaria y normas de conflicto españolas en materia societaria en la actualidad}

\section{Nacionalidad de las sociedades}

68. Las consecuencias que produce la nueva perspectiva comunitaria relativa a la cuestión de la Ley aplicable a las sociedades, sobre las normas de conflicto españolas en la materia, son extraordinariamente relevantes. Para comprenderlas en todo su alcance, varios datos previos deben recordarse.

69. a) El art. 9.11.I Cc. indica que las personas jurídicas, y por tanto las sociedades, se rigen por su «Ley nacional» correspondiente. Ahora bien, la noción «nacionalidad de las personas jurídicas», como explica la doctrina (J.-P. Niboyet, C. Paz-Ares, B. Audit, G. Kegel, E. Pérez Vera, etc.), no es más que un «modo antiguo» de expresar que la persona jurídica presenta un «vínculo» con un Estado ${ }^{116}$. Y como presenta un vínculo estrecho con ese

cases, both in the field of company law and of IPL in general. The committee therefore refrained from making a proposal and considers that it is sufficient to take the same approach in international company law as is taken in other fields. This decision to dispense with a proposal is supported by the absence of such provisions in the majority of European IPL acts. The provisions which do exist (Article 21 of the Portuguese Civil Code, Article 8 of the Romanian IPL Act, Article 12(5) of the Spanish Civil Code [sic] and Paragraph 8 of the Hungarian IPL Regulation) are worded generally. It is therefore considered more appropriate to leave the question of the treatment of fraudulent conduct to the courts. This applies to both the proposed EC regulation and the German national legislation».

${ }^{116}$ El número de trabajos doctrinales sobre la cuestión de la «nacionalidad» de las personas jurídicas es incalculable. Un panorama correcto se obtiene a partir de los trabajos de

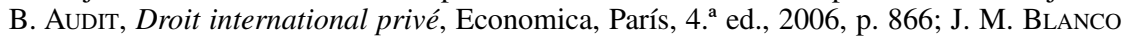
FERNÁNDEZ, «La nacionalidad de la sociedad en la ley de sociedades anónimas», RDM, 1992, núms. 203-204, pp. 245-276; L. CAFLISCH, «La nationalité des sociétés commerciales 
Estado, las Leyes de dicho Estado deben regir la formación y el funcionamiento interno de dicha persona jurídica (F. CAPOTORTI, D. DAMASCELLI ${ }^{117}$ ). Por tanto, se puede afirmar que, diga lo que diga el art. 9.11 Cc., las personas jurídicas no ostentan ninguna nacionalidad. Es más correcto afirmar, simplemente, que toda sociedad se rige por un Derecho estatal determinado. La noción «nacionalidad de las personas jurídicas» no es análoga a la noción de «nacionalidad de las personas físicas» (J.-P. NIBOYET ${ }^{118}$ ). En efecto, las personas jurídicas «españolas» no son la «base subjetiva» del Estado español (STS 17 enero 1912, STS 14 junio 1951, STS 14 junio 1974, STS, Sala 3. a, 14 marzo 1977).

70. b) A la hora de concretar la nacionalidad de las sociedades, el art. 9.11.I Cc. no indica qué sociedades son «españolas» y qué sociedades no lo son. Para resolver el problema hay que acudir a otras normas del Derecho español. Se trata, en sustancia, de los arts. 5 LSA, 6 LSRL y 28 Cc.

71. c) Las normas españolas de DIPr. relativas a las sociedades pueden precisar la Ley aplicable a todas las sociedades. Es cierto que las normas

en droit international privé», ASDI, 1967, vol. XXIV, pp. 119-160; A. L. CAlvo CaravaCA, «Nacionalidad (de Sociedades)», EJB, 1995, pp. 4385-4389; M. CHECA MARTínEZ, «La ley 19/1989 de reforma parcial y adaptación de la legislación mercantil en materia de sociedades: la nacionalidad de la sociedad anónima», REDI, 1989, vol. XLI, pp. 662-664; R. EGEA IBÁÑEZ, «Nacionalidad de las sociedades. Adquisición por una sociedad extranjera de la nacionalidad española», Real Academia de Legislación y Jurisprudencia, Murcia, 1984; ID.: «Nacionalidad de las sociedades», RCDI, 1984, pp. 1155-1182; F. GimÉNEZ ARTIGUES, «¿Existe una nacionalidad de las sociedades mercantiles?, RJC, 1946, pp. 39-51; ID., La nacionalidad de las sociedades mercantiles, Barcelona, Bosch, 1949; A. KLEY-STRUller, «Die Staatszugehörigkeit juristischer Personen», RSDIDE, 1991, pp. 163-202; Y. LousSOUARN, «Nationalité des sociétés et Communauté Economique europénne», Revue de Jurisprudence commerciale, 1990, pp. 145-165; J.-P. NIBOYET, «Existe-t-il vraiment une nationalité des sociétés?, RCDIP, 1927, pp. 402-417; M. PEÑA Y BERNALDO DE QuIRós, «Art.28 Cc.», Com.Cc. y Comp.For., 1978, pp. 775-806; ID., «Art.28 Cc.», Com.Cc. y Comp.For., 2. ${ }^{a}$ ed., 1993, pp. 689-760; D. PoHÉ, La nationalité des sociétés dans les pays en voie de developpement, tesis, Burdeos, 1989; J. J. Pretel SERRANo, «Nacionalidad y domicilio de la Sociedad Anónima», Anales de la Academia Matritense del Notariado, 1991, vol. XXX, pp. 187-190; F. SÁNCHEZ CALERO, «La nacionalidad de la sociedad anónima», Revista de Derecho de Sociedades, 1993, vol. I, pp. 15-60; F. XIMÉnEZ NorÉs, «La nacionalidad de las empresas multinacionales», $A C$, 1986, núm. 39, pp. 2701-2715; C. PAZ-ArES / F. J. GARCIMARTín, «Conflicto de leyes y garantías sobre valores anotados en las cuentas de intermediarios financieros», $R D M, 2000$, pp. 1479-1501. Aunque referido a las fundaciones, es muy útil el enfoque que sobre la cuestión de la «nacionalidad de las personas jurídicas» ofrece B. CAmpuZANo DíAz, «Las fundaciones extranjeras en la nueva ley sobre Fundaciones», BIMJ, núm. 1745 de 5 junio 1995, pp. 3205-3225.

${ }^{117}$ F. CAPOTORTI, La nazionalità delle società, 1953; D. DAMASCELLI, I conflitti di legge in materia di società, Cacucci Editore, Bari, 2004, pp. 76-78.

118 J.-P. NiBoyet, «Existe-t-il vraiment une nationalité des sociétés?, RCDIP, 1927, pp. 402-417. 
españolas que determinan la «nacionalidad» de las personas jurídicas sólo indican cuándo tales entes tienen «nacionalidad española». $\mathrm{O}$ en otros términos: sólo indican cuándo la Ley española rige la sociedad. No obstante, tales normas deben «bilateralizarse», de modo que indicarán qué Ley estatal, española o extranjera, rige cualquier sociedad. La jurisprudencia española ha seguido esta línea: (a) La SAP Granada 9 marzo 2003 estimó que una sociedad extranjera era «taiwanesa» porque quedó acreditado su domicilio social en Taiwán y su sujeción al Derecho de tal país; (b) La SAP Baleares 18 marzo 2005 estimó que una sociedad estaba sometida al Derecho de las Islas Vírgenes puesto que allí tenía su domicilio estatutario y estaba organizada con arreglo al Derecho de tales islas. La tesis contraria, que sostiene que la Ley aplicable a las sociedades debe fijarse a través de la consulta de las «normas extranjeras de DIPr.», debe ser rechazada. El rechazo de esta tesis es sencillo de comprender: la «nacionalidad» de las sociedades no es una verdadera «nacionalidad» y por tanto no tiene por qué ser acreditada con arreglo a un Derecho estatal determinado, como sí sucede, sin embargo, con las personas físicas.

\section{Criterio utilizado para determinar la Ley reguladora de las sociedades corporativas}

72. Pues bien, el art. 5 LSA y art. 6 LSRL deben ser interpretados y aplicados del siguiente modo ${ }^{119}$.

${ }^{119}$ Las aportaciones doctrinales sobre las normas de DIPr. españolas relativas a las sociedades son incontables. Vid., en general, A.-L. Calvo CaravaCa / J. CARrascosa González, «Personas jurídicas y sociedades mercantiles», en Derecho Internacional Privado, vol. II, 7. ${ }^{\text {a }}$ ed., Granada, Comares, 2006, pp. 295-336; A.-L. Calvo CARAvaCA, «Las sociedades de capital en el tráfico jurídico internacional», $R G D$, n. 525, 1988, pp. 3679-3701; A. L. CALvo Caravaca en J. D. González Campos y otros, Derecho internacional privado - parte especial, 6. ${ }^{\text {a }}$ ed., Madrid, Eurolex, 1995, pp. 84-89; A. L. CALvo CARAVACA, «Las sociedades de capital en el tráfico jurídico internacional», $R G D$, 1988, pp. 3679-3701; ID., «Art.

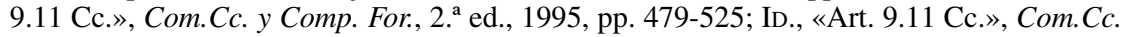
Min. Justicia, 1991, pp. 103-105; R. ARENAS GARCíA, «La lex societatis en el Derecho de las sociedades internacionales», Derecho de los Negocios, 70/71, pp. 11-26; J. M. BLANCO FERNÁNDEZ, «La nacionalidad de la sociedad en la Ley de Sociedades Anónimas», RDM, n. 203/204, 1992, pp. 245-276; M. CheCA MARTínEZ, «DIPr. de sociedades en el nuevo RRM», REDI, 1990, vol. XLII, pp. 306-309; ID., «Persona jurídica (Derecho internacional privado)», EJB, 1995, pp. 4864-4865; ID., «Sociedad (Derecho comunitario)», EJB, 1995, pp. 6266-6268; ID., «Sociedad (Derecho internacional privado)», EJB, 1995, pp. 6268-6270; R. EGEA IBÁÑEZ, «Reconocimiento de sociedades extranjeras. Reconocimiento de sociedades en la Comunidad Económica europea. Convenio de Bruselas de 29 de febrero de 1968. Convenio de la Haya de 1956», Revista de Derecho Notarial, julio/diciembre 1985, pp. 162-185; F. ESTEBAN DE LA ROSA, «Vía libre a la movilidad de las sociedades en la UE: la STJCE de 30 septiembre 2003 (as. C-167/01), Inspire Art», La Ley, núm. 5924, 31 diciembre 2003; R. EGEA IBÁÑEZ, «Reconocimiento de sociedades extranjeras. Reconocimiento de sociedades 
73. a) Existe una regla general para determinar la Ley aplicable a las sociedades en DIPr. español. La sociedades se rigen por la Ley del país con arreglo a la cual se han constituido (F. J. GARCIMARTín AlFÉREZ ${ }^{120}$ ). En con-

en la Comunidad Económica europea. Convenio de Bruselas de 29 de febrero de 1968. Convenio de la Haya de 1956», Revista de Derecho Notarial, julio/diciembre 1985, pp. 162-185; E. Gabarro Samso / J. M. Puig Salellas, «Conflictos de leyes en sociedades civiles y mercantiles», Ponencias presentadas a los congresos internacionales del Notariado Latino, Madrid, 1975, pp. 673-712; F. J. GARCIMARTín AlfÉREZ, Derecho de sociedades y conflictos de leyes: una aproximación contractual, Cuadernos Mercantiles, Ed. de Derecho Reunidas, Madrid, 2002; ID., «Derecho de sociedades: problemas de Ley aplicable», en J. F. DeLGADO DE MiguEL (Coord.), Instituciones de Derecho Privado, Tomo VI, Mercantil, Derecho de Sociedades. Parte General, Thomson-Civitas, 2003, pp. 19-152; M. GARDEÑES SANTIAGO, Las fundaciones en DIPr. español, Madrid, Eurolex, 2003; M. GARDEÑES SANTIAGO, «El Derecho internacional privado de fundaciones a la luz de la nueva Ley 50/2002, de 26 de diciembre», REDI, vol. LVI, 2004, pp. 251-271; J. L. IgLeSIAS BuHIGUES, «Reconocimiento de las sociedades y personas jurídicas en la CEE y en Derecho español», AESJ, 1977, vol. VI, Granada, pp. 129-179; M. OLIVENCIA RUIZ, «Nacionalidad y domicilio de las sociedades anónimas», Academia Sevillana del Notariado, tomo VII, Edersa, 1993, pp. 489-511; E. PÉREZ VerA, «Art.9.11 Cc.», CRef.Cc., 1977, pp. 499-505; ID., «Art.9.11 Cc.», Com.Cc. y Comp.For., 1978, pp. 200-205; J. J. PRETEL SERRANO, «Nacionalidad y domicilio de la sociedad anónima», AAMN, tomo XXX, Homenaje a De La Cámara Álvarez, vol. 1, 1991, pp. 179-244; F. SÁNCHEZ CALERO, «La nacionalidad de la sociedad anónima», Rev. Sociedades, n. 1, 1993, pp. 45-60; M. TORRES BLÁZQUEZ, «El centro de intereses principales y los grupos de sociedades», REDI, 2003-II, vol. LV, pp. 1128-1131.

${ }^{120}$ Esta radical afirmación se debe al mérito de F. J. GARCIMARTín AlFÉREZ. Anteriormente, la doctrina había interpretado el art. $9.11 \mathrm{Cc}$. y el art. 5 LSA de modos muy diferentes, contrapuestos y enfrentados (= sede real, domicilio-constitución, etc.). La interpretación de F. J. GARCIMARTíN ALFÉREZ resulta la más adecuada tanto desde el punto de vista de su racionalidad económica como desde el punto de vista de la coherencia global del sistema español de DIPr. Vid., en este sentido, F. J. Garcimartín AlfÉREZ, Derecho de sociedades y conflictos de leyes: una aproximación contractual, Cuadernos Mercantiles, Ed. de Derecho Reunidas, Madrid, 2002, pp. 298-311; ID., «Derecho de sociedades: problemas de Ley aplicable», en J. F. DELGADO DE Miguel (CoORd.), Instituciones de Derecho Privado, Tomo VI, Mercantil, Derecho de Sociedades. Parte General, Thomson-Civitas, 2003, pp. 19-152; ID., «La Sitztheorie es incompatible con el Tratado CE (algunas cuestiones del Derecho internacional de sociedades iluminadas por la sentencia TJCE de 9 de marzo de 1999)», RDM, 1999, pp. 645 y ss.; ID., «La Sentencia 'Centros': el 'status questionis' un año después», Not.UE, n. ' 195, 2001, pp. 79-96; ID., «La sentencia Centros del Tribunal de Justicia de las Comunidades Europeas: una visión a través de los comentarios», Revista Electrónica de Estudios Internacionales, 2000, pp. 2 ss.; ID., «La sentencia 'Überseering' y el reconocimiento de sociedades extranjeras: se podrá decir más alto, pero no más claro», $R D M$, n. 248, 2003, pp. 663-682. Un exhaustivo repaso a todas las interpretaciones de la doctrina y jurisprudencia española sobre el criterio de conexión en materia de sociedades mercantiles puede examinarse en A. L. CALVO CARAVACA, «Las sociedades de capital en el tráfico jurídico internacional», $R G D$, n. 525, 1988, pp. 3679-3701; A. L. CALVO CARAVACA, «Persona jurídica», en J. D. GONZÁLEZ CAMPOS Y OTROS, Derecho internacional privado - parte especial, 6. ${ }^{\mathrm{a}}$ ed., Madrid, Eurolex, 1995, pp. 84-89; A. L. CALVO CARAVACA, «Las sociedades de capital en el tráfico jurídico internacional», RGD, 1988, pp. 3679-3701; ID., «Art.9.11 Cc.»,

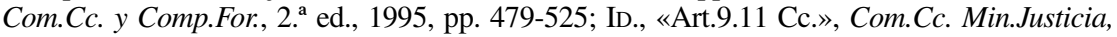
1991, pp. 103-105. 
secuencia, deberán fijar su domicilio estatutario en dicho país. Pero la regla general es la mera constitución de la sociedad con arreglo a la Ley de un concreto país. El domicilio en dicho país no es, en sí mismo, un «punto de conexión». Fijar el domicilio estatutario en un país es, simplemente, una consecuencia necesaria de haberse constituido con arreglo a la Ley de dicho país. Por ello, una sociedad se rige por el Derecho español si se ha constituido con arreglo al Derecho español, si bien para quedar perfectamente constituida debe fijar su domicilio en el territorio español. Otra forma de contemplar la regla española de DIPr. es afirmar que el «domicilio estatutario» opera como punto de conexión porque los socios, al fijar en España dicho domicilio, eligen la Ley española como Ley rectora de la sociedad (A.-L. CALvo CARAVACA / J. CARRASCOSA GONZÁLEZ ${ }^{121}$ ). Ejercen esa elección de Ley mediante la fijación del domicilio de la sociedad en España. De hecho, y como subrayan P. KINDLER y D. ZIMMER, la Incorporation Theory reviste variantes ampliamente difundidas en las legislaciones del mundo: fijar la sede estatutaria en un país es un modo de elegir la Ley de ese país, y proceder al Registro de una sociedad en el Registro de un país es también elegir la Ley de dicho país $^{122}$. Por ello, si una norma de DIPr. indica que la Ley reguladora de las sociedades es la Ley de su domicilio estatutario, o la Ley del país donde se ha registrado o inscrito, o la Ley con arreglo a la cual la sociedad se ha constituido, en el fondo, está diciendo siempre lo mismo. Por ello, puede afirmarse que el punto de conexión principal en materia societaria es, en DIPr. español, por tanto, la «autonomía de la voluntad» (STS 22 marzo 1983, RDGRN 11 septiembre 1990). Además, la norma debe ser bilateralizada. Así, en el caso de una sociedad constituida con arreglo a la Ley de otro país y con domicilio estatutario en dicho país, se regirá por la Ley de ese país, sea éste cual sea. Incluso aunque se trate de uno de los conocidos como «paraísos fiscales», como las Islas Vírgenes (SAP Baleares 18 marzo 2005). Por otra parte, a la hora de precisar la Ley aplicable a la sociedad, resultan totalmente indiferentes el lugar de constitución de la sociedad, la sede de dirección o el país donde despliega sus principales actividades económicas. Toda sociedad que fije en España su domicilio estatutario es «española». Como consecuencia de ello, la sociedad que ha fijado su domicilio estatutario en España debe constituirse con arreglo al Derecho español. Naturalmente, los socios pueden fijar un domicilio estatutario en España con total libertad, esto es, aunque la sociedad no tenga en España su sede de dirección o su principal explotación (= el art. 5 LSA nada exige en este sentido). En el caso de que así sea, para

${ }^{121}$ A.-L. Calvo Caravaca / J. Carrascosa González, «Personas jurídicas y sociedades

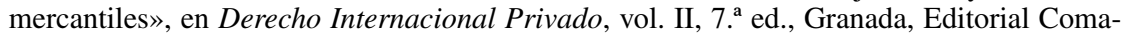
res, 2006, pp. 295-336.

${ }_{122}$ P. KINDLER, «Aspetti essenziali di un futuro regolamento comunitario sulla legge applicabile alle società», RDIPP, 2006-III, pp. 657-674, esp p. 662; D. ZIMMER, «Ein Intenationales Gesellschaftrecht für Euorpa», RablesZ, 2003, pp. 298-299. 
no perjudicar a terceros, éstos podrán considerar como domicilio el que figure inscrito como tal en el Registro Mercantil cuando no coincida con la sede de dirección o la principal explotación (art. 6.2 LSA).

74. b) Pero existe una regla excepcional o cláusula de salvaguarda diseñada para luchar contra las «Pseudo-Foreign Corporations». La posibilidad de constituir una sociedad con arreglo a un Derecho extranjero entraña ciertos peligros para los sujetos que contratan y se relacionan con la sociedad. Tales peligros surgen porque una sociedad podría constituirse con arreglo a un Derecho societario extranjero «permisivo» y fijar su domicilio estatutario en dicho país extranjero, en uno de los llamados «países oasis». Con ello, los particulares persiguen la aplicación de un Derecho extranjero a una sociedad cuyos elementos están totalmente vinculados con España. Es el llamado y antes citado «síndrome de Delaware», perfectamente descrito e ilustrado por P. Blanco-Morales Limones: el State norteamericano de Delaware dispone de una legislación permisiva en materia societaria y de impuestos sobre sociedades, razón por la que miles de sociedades se constituyen con arreglo a la Ley de dicho State aunque no tienen la más mínima conexión sustancial con Delaware ${ }^{123}$. Pues bien: existe el riesgo de que una sociedad totalmente integrada en el mercado español, con explotaciones económicas y/o sede de dirección en España, quedara regulada por la Ley de un país extranjero con el que no tiene contacto alguno, sólo porque las partes, en los estatutos sociales, han fijado la sede social en el territorio de dicho país y han constituido la sociedad con arreglo a la Ley de dicho país. Ello es inconveniente porque supondría una disminución de la autoridad de la legislación española sobre sociedades, la introducción en el tráfico jurídico español de sociedades constituidas con arreglo a legislaciones presumiblemente exóticas que no garantizan la protección de los intereses de los socios ni la protección de los acreedores. Los arts. 5.2 LSA y 6.2 LSRL tratan de evitar esta situación y protegen a los terceros y al mercado español frente a los efectos perniciosos de Leyes extrañas y poco fiables. Por eso, cuando una sociedad que se presenta en el mercado como una sociedad «española», pues está dirigida exclusivamente desde España, y cuyas actividades se realizan exclusivamente en España, deben protegerse las expectativas de los terceros. Y ello se logra si se evita que dicha sociedad quede regulada por un Derecho extranjero de imprevisible aplicación para los terceros. Se lucha, así, contra estas «falsas sociedades extranjeras», también conocidas como Pseudo-Foreign Corporations o "société boîte aux lettres» (F. J. GARCIMARTín AlfÉREZ ${ }^{124}$ ).

${ }^{123}$ P. Blanco-Morales Limones, Transferencia internacional de sede social, Pamplona, 1997, pp. 53-59.

${ }^{124}$ F. J. Garcimartín Alférez, Derecho de sociedades y conflictos de leyes: una aproximación contractual, Cuadernos Mercantiles, Ed. de Derecho Reunidas, Madrid, 2002, pp. 298-311. 
75. Para combatir las Pseudo-Foreign Corporations que pretenden operar en el mercado español, y proteger así a los terceros que participan en dicho mercado, el art. 5.2 LSA y art. 6.2 LSRL indican que las sociedades con «principal establecimiento o explotación» en territorio español están obligadas a fijar su domicilio estatutario en España y a constituirse con arreglo a la Ley española. Sin embargo, y aquí está lo relevante, como se ha dicho, los arts. 5.2 LSA y 6.2 LSRL no pueden operar, en ningún caso, en «casos comunitarios». La «regla excepcional de DIPr.» no puede aplicarse en ningún caso cuando la sociedad tiene su domicilio estatutario en un Estado miembro, pero todos los demás elementos de la sociedad (= lo que incluye su «principal establecimiento» o «principal explotación») se localizan en España. La UE presenta un grado elevado de integración entre los Estados miembros. El mercado único exige admitir la movilidad total de sociedades e impide hablar de fraude, Bad Forum Shopping o abuso de Derecho. Ésa es la razón por la que el art. 5.2 LSA y 6.2 LSRL no son aplicables en relación con supuestos comunitarios.

76. En el estado actual del Derecho comunitario (= las normas de conflicto comunitarias en materia societaria no existen a fecha 13 septiembre 2006), puede afirmarse que las autoridades españolas deben poner en marcha la «regla de reconocimiento comunitario de situaciones jurídicas» (Anerkennungsprinzip). De ese modo, una sociedad legal y válidamente constituida en un Estado miembro con arreglo a sus normas de DIPr. debe ser considerada como una sociedad legal y válidamente constituida también en España. Resulta totalmente irrelevante al efecto cuál sea el lugar de principal explotación de la sociedad o el lugar de dirección de ésta.

Ello comporta, a su vez, una consecuencia refleja de radical importancia. El foro exclusivo para las personas jurídicas recogido en el art. 22.2 R.44/2001 se ve profundamente afectado. El precepto citado indica que en materia de validez, nulidad o disolución de sociedades y personas jurídicas, así como en materia de validez de las decisiones de sus órganos, serán competentes con carácter exclusivo los tribunales del Estado miembro en que la sociedad o persona jurídica estuviera domiciliada, siempre que los tribunales conozcan a título principal y no incidental. Pues bien, dicho precepto indica igualmente que, para determinar dicho «domicilio», el tribunal aplicará «sus reglas de Derecho internacional privado». Por tanto, para saber si una sociedad está domiciliada en España, se aplicará el DIPr. español en materia societaria. Pero la incidencia de la jurisprudencia del TJCE en la trilogía «Centros - Überseering - Inspire Art» (STJCE 9 marzo 1999, Centros, STJCE 5 noviembre 2002, Überseering, STJCE 30 septiembre 2003, Inspire Art), en el art. 22.2 R.44/2001, cambia todo el escenario legal (M. V. BenEDETTELLi ${ }^{125}$ ). Todo Estado miembro

125 M.V. BenedetTelli, «Criteri di giurisdizione in materia societaria e diritto comunitario», RDIPP, 2002, pp. 879-922. Esta solución aparece ya avanzada hace muchos años por 
puede utilizar el criterio que prefiera para fijar la «Ley aplicable» a las sociedades y el «domicilio» de las sociedades (= el art. 48 TCE no es una norma de conflicto y, por tanto, no obliga a los Estados miembros a seguir ningún punto de conexión determinado en materia de sociedades). Sin embargo, ello no puede tener como resultado «obligar» ex lege a una sociedad que dispone de su sede social, administración central o centro de actividad principal en un Estado miembro a que tenga su «domicilio» o «sede» en otro país concreto. Ello es inaceptable porque supondría un obstáculo a la «libertad de establecimiento» de las sociedades en la UE. Resultado: el art. 5.2 LSA y los preceptos de otras leyes societarias españolas que siguen su estela (= el art. 6.2 LSRL por ejemplo), no pueden aplicarse para obligar a fijar en España el domicilio de una persona jurídica porque el «principal establecimiento o explotación» de la sociedad radica en España, siempre que la sociedad haya sido constituida de conformidad con la legislación de un Estado miembro y tenga su sede social, administración central o centro de actividad principal en un Estado miembro (art. 48 TCE). Ejemplo: la sociedad «Becks» es una sociedad incorporated to English Law. Sin embargo, dicha sociedad dispone de su explotación principal en España. Esta sociedad, a los ojos de un tribunal inglés, está domiciliada en Inglaterra. Pero para una autoridad española, la misma sociedad está domiciliada en España, ya que a tenor del DIPr. español (art. 5.2 LSA), la sociedad está obligada a tener su domicilio en España al tener en España su explotación principal. Pero la solución es engañosa, falsa y contraria al Derecho comunitario, y por lo tanto, plenamente rechazable: el DIPr. español no puede obligar a considerar que la sociedad «Becks», legalmente incorporated to English Law está domiciliada en España, pues ello perjudicaría la libertad de establecimiento de dicha sociedad.

\section{Reflexión final}

77. La correcta combinación de la regla general sobre la Ley aplicable a las sociedades en DIPr. español (= art. 9.11 Cc. + arts. 5 LSA y 6 LRSL y similares) con la «regla de reconocimiento comunitario de situaciones jurí-

el trabajo pionero de P. Blanco-Morales Limones, «Art. 5.5», en A.-L. Calvo Caravaca (DIR.), Comentario al convenio de Bruselas relativo competencia judicial internacional y ejecución de resoluciones judiciales en materia civil y mercantil, publicada por la Universidad Carlos III de Madrid y el Boletín Oficial del Estado, Madrid, 1994, pp. 139-147. Vid. igualmente, R. CARO GÁNDARA, La competencia judicial internacional en materia de régimen interno de sociedades en el espacio jurídico europeo, Civitas, Madrid, 1999, pp. 55-59 y F. J. GARCIMARTín ALFÉREZ, «La competencia judicial internacional para los litigios societarios en el Convenio de Bruselas. A propósito del 'caso Torras' ante los tribunales españoles», Gaceta Jurídica UE, octubre / noviembre, 1999, pp. 19-31. 
dicas» (Anerkennungsprinzip) hace posible afirmar que el DIPr. societario español ha entrado en una nueva era ${ }^{126}$. Es, como indica P. DYRBERG, la era de la completa y total libre circulación de sociedades en la UE, de la libre competencia entre ordenamientos societarios y de la plena y efectiva realidad de un «mercado abierto» ${ }^{127}$. Es una nueva etapa económica de la UE, en la que el detestable dirigismo estatal debe ser, finalmente, abandonado. Como han subrayado S. TAFANI / R. CARUso, la revolución del Derecho societario de los Estados miembros, guiada por el criterio de la Incorporation Theory, no ha hecho más que comenzar ${ }^{128}$. Abróchense los cinturones. Vamos a despegar.

${ }^{126}$ Como sucede.

${ }^{127}$ P. DYRBERG, «Full free movement of companies in the European Community at last?», Eur.L.Rev., 28, 4, 2003, pp. 528-537.

${ }^{128}$ S. TAFANI / R. CARUSO, Il nuovo Diritto europeo delle società di capitali, Roma, 2005, pp. 43-44. 